\title{
Kernos
}

Revue internationale et pluridisciplinaire de religion grecque antique

$24 \mid 2011$

Varia

\section{Epigraphic Bulletin for Greek Religion 2008 (EBGR 2008)}

\section{Angelos Chaniotis}

\section{(2) OpenEdition \\ Journals}

Electronic version

URL: http://journals.openedition.org/kernos/1968

DOI: 10.4000/kernos.1968

ISSN: 2034-7871

\section{Publisher}

Centre international d'étude de la religion grecque antique

Printed version

Date of publication: 1 January 2011

Number of pages: 205-261

ISSN: 0776-3824

\section{Electronic reference}

Angelos Chaniotis, « Epigraphic Bulletin for Greek Religion 2008 (EBGR 2008)», Kernos [Online], 24

2011, Online since 01 February 2014, connection on 15 September 2020. URL : http://

journals.openedition.org/kernos/1968 
Kernos 24 (2011), p. 205-261.

\section{Epigraphic Bulletin for Greek Religion 2008 (EBGR 2008)}

The 21st issue of the Epigraphic Bulletin for Greek Religion presents a selection of the epigraphic publications of 2008 and many additions to earlier issues. Following the practice of the most recent issues, emphasis was placed on the presentation of new corpora and editions of new texts, rather than on summarizing books or articles that use epigraphic material. Several geographical and thematic corpora take the lion's share in this issue; they assemble epitaphs from Attica (13) and Kos (19); the late antique inscriptions of Athens (145); the inscriptions of Aigina (62), the cities of Achaia (136), Thespiai (137), Miletos (69), Boubon (90), Kaunos (109), the Burdur Museum (70), and the area of Mt. Hermon in Syria (5); dialect inscriptions of Sicily (40); and inscriptions pertaining to the cult of the Great Gods in Samothrace (38).

There are numerous new texts of great interest, of which I mention a few. An inscription from the oracle of Apollon Selinaios contains the first sacred manumission from Euboia (121). There are several cult regulations, of which the one from Karystos concerning priestly perquisites (26) and several fragments in Miletos (69) deserve special mention. An honorary decree of the cult association of Agathe Thea in Athens describes the duties of the association's supervisor, such as the preparation of the goddess' throne and the setting up of a torch in all meetings of the association (155). In Miletos, an unusually large number of oracles of Apollon Didymeus requested the erection of altars for the cult of various gods (69). An honorary inscription from Olbia presents evidence for the distinctions made in ritual between citizens and foreigners: the use of separate altars (75). A new inscription from Delion with the accounts of the local agonistic festival provides information concerning the various expenses and the funding of festivals (21). In Miletos, a fragment attests to the phenomenon of leaving bequests to sanctuaries (60). A new inscription from Kos attests for the first time to the festival Tycheia on this island (20). A new honorary decree of Mylasa (73) establishes a commemorative anniversary for the restoration of freedom and democracy and introduces the cult of Olympichos (73). In Kos, a letter of Emperor Claudius clearly shows the importance of reciprocity in imperial cult: the emperor explictly states that he grants privileges to the cities that performed sacred celebrations for him (20). A new fragment of the philosophical inscription of Diogenes of Oinoanda criticizes Apollon's oracles (64); the fact that a roughly contemporary oracle from Miletos designates Apollon as the god who does not lie (apsendestatos, 69) certainly is a response to such critics. A dedication from the area of Sidon refers to one god (Melikertes) serving as messenger of another (3), which provides new evidence for the concept of the divine in the Imperial period. In a funerary epigram from Athens (96), Apollonios explains how he selected a place in the countryside to construct his grave following advice given to him in a dream and by means of an oracle. Finally, an Athenian curse tablet from the sanctuary of Polykrates and Palaimon is the first defixio known with certainty to have been found in a shrine (81).

The inscriptions discussed in this issue, both the inedita and texts contained in corpora, are of interest for a variety of subjects: cult offices, sacred property, festivals and contests, rituals, eschatological ideas - for instance the belief that a privileged position in the underworld has to be earned through moral qualities (13) -, magic, the relation between Christianity and 
paganism (e.g. 51. 107), the convergence of religious vocabulary, the shaping of religious identities in Late Antiquity (13), and religious mentality. As regards the latter, I single out a grave epigram from Thespiai, in which a woman who died young bitterly complains that the Muses did not listen to the prayers of her father, who was a priest (137). Finally, I point to several texts that show the importance of dedications in families' commemorative activities. In the sanctuary of Apollon Lairmenos near Hierapolis a man chose the altar of Artemis to announce the dedication of a slave because this altar had been dedicated by his father (1); and in Thespiai a priestess commemorated the fact that a statue of Dionysos had been dedicated by her ancestors (137).

The principles explained in Kernos 4 (1991), p. 287-288, and Kernos 7 (1994), p. 287, also apply to this issue. Abbreviations that are not included in the list are those of L'Année Pbilologique and J.H.M. STRUBBE (ed.), Supplementum Epigraphicum Graecum. Consolidated Index for Volumes XXXVIXLV (1986-1995), Amsterdam, 1999, as well as of later volumes of the SEG. If not otherwise specified, dates are BCE. Georgy Kantor (New College, Oxford) summarized Russian publications; Michael Anthony Fowler (Columbia University) improved the English text.

\section{Abbreviations}

Ancient Macedonia VII:

Ancient Macedonia VII. Macedonia from the Iron Age to the Death of Philip II. Papers Read at the Seventh International Symposium Held in Thessaloniki, October 14-18 2002, Thessaloniki, 2007.

Bosporskëj fenomen 2: Bosporskë fenomen: Sakralnyj smysl regiona, pamiatnikov, nakbodok. 2, St. Petersburg, 2007.

Cirene e la Cirenaica:

L. Gasperini - S.M. Marengo (eds), Cirene e la Cirenaica nell'Antichità, Tivoli, 2007.

Eucharisterion:

A.D. STOLYAR et al. (eds), EYXAPILTHPION: Antikovedcheskoistoriograficheskëy sboknik pamiati Ya.V. Domanskogo, St. Petersburg, 2007.

Festschrift Schwertheim: $\quad$ E. WINTER (ed.), Vom Euphrat bis zum Bosporus. Kleinasien in der Antike. Festschrift für Elmar Schwertheim zum 65. Geburtstag, Bonn, 2008 (Asia Minor Studien 65).

Koinè pontique:

A. BRESSON - A. IVANTCHIK - J.-L. FERRARY (eds), Une koinè pontique, Bordeaux, 2007.

Mikros Hieromnemon:

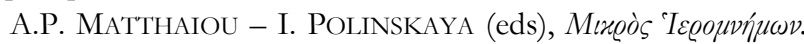

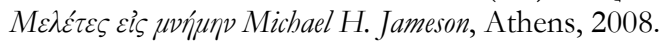

Thrace in the Graeco-Roman World. A. IAKOVIDOU (ed.), Thrace in the Graeco-Roman World. Proceedings of the 10th International Congress of Thracology, KomotiniAlexandroupolis 18-23 October 2005, Athens, 2007.

\section{Selected Topics}

Geographical areas (in the sequence adopted by SEG)

Attica: Athens: 13. 23. 33. 48. 81-82. 84. 86. 92. 95-98. 106. 113. 123. 126. 127. 145. 155. 158; Acharnai: 133; Eleusis: 23. 29-30; Myrrhinous: 83; Piraeus: 132; Thorikos: 148. Peloponnese: 84. Aigina: 62. 134. Kleonaia: Nemea: 120. Argolis: Argos: 87. Epidauros: 144. Lakonia: 100; Geraki: 31-32; Therapne: 88. Messene: 149. Elis: 154; Olympia: 34. 114. 128-129. Achaia: 136. Boiotia: 84. 88. 103; Tanagra: 7. 21. Delphi: 18. 34. Phokis: 84. 
Lokris: 84. Akarnania: Alyzia: 91. Thessaly: 84; Atrax: 37; Mopseion: 50; Pherai: 14. Epeiros: Nikopolis: 24. Illyria: Apollonia: 124; Grammata: 61. Macedonia: 111; Dikaia: 156-157; Drama: 94; Kalindoia: 146; Sarte: 125. Thrace: 2. 111; Philippopolis: 142; Serdica: 112. Dacia: 9. Moesia: Histria: 11. 17; Tomis: 12. North Shore of the Black Sea: 151; Bosporos: 162; Chersonesos in Tauris: 104; Hermonassa: 130; Kepoi: 93; Myrmekion: 21; Neapolis: 72; Olbia: 57. 74-76. 102; Pantikapaion: 78. 159; Tyras: 77. Delos. 8. 68. 119. 135. 143. Rhodes: 58; Lindos: 53. Naxos: 99. Kos: 19-20. 63. 105. Samos: 79. Thasos: 49. 111. Samothrace: 30. 38. 58. 109. Euboia: Amarynthos: 89; Eretria: 71; Histiaia: 121; Karystos: 26. Crete: Eleutherna: 147; Gortyn: 110; Kydonia: 126; Lebena: 144; Palaikastro: 6. Italy: 16. 51. 101; Rome: 144. Sicily: 40. 131. 160; Syracuse: 34. Britain: 152-153. Asia Minor: 107; Karia: Aphrodisias: 43; Attouda: 116; Kaunos: 109; Knidos: 122; Labraunda: 73; Panamara: 138; Stratonikeia: 138. Ionia: Erythrai: 52; Klaros: 44. 47; Miletos: 59-60. 66. 69; Tralleis: 43. Troas: Alexandreia/Troas: 56: Kyme: 65. 108. Mysia: Kyzikos: 41. 63; Pergamon: 36. Bithynia: Hieron: 118; Kalchedon: 118. Phrygia. Hierapolis: 1. Lykia: 117; Boubon: 90; Oinoanda: 64. Kilikia: 141. Cyprus: 85; Amathous: 10; Kafizin: 67; Kourion: 150. Kommagene: 46. Syria: 3-5. 35. Kyrene: 45.

account: 8. 18. 21. 137

afterlife: 5. 13-14. 57. 78. 137. 145. 161; see also Greek words

agon: see s.v. contest, festival

altar: 5. 27. 35. 45. 62. 69. 75. 109. 156; funerary: 90

amulet: 16. 27-28. 51. 55. 62.112. 147.153. 162

ancestral tradition: 44 (patria). 109

angel: 3. 5. 62. 160

animal: see s.v. boar, bull, cow, dog, eagle, kid, ox, sheep, snake

apotropaic text: 145

archaism: 68

aretalogy: 119

assembly, discussion of sacred matters: 75. 137; after the City Dionysia: 98

association, cult: 5. 12. 19. 23. 58. 62. 67. 69. 80. 99. 109. 155; see also Greek words

asylia: 20.63. 69

axe, double: 50

baetyl: 109

banquet: 21. 62.73. 90.138. 150; funerary 40.90

bequest, left to god: 60

boar: 53.156

boundary stone, of grave: 13. 19; of association: 69; of sanctuary: 30. 62. 131. 137

building, funded with sacred funds: 5

bull: 73

burial, within city wall: 41

calendar: 156 (Eretria)

cenotaph: 48

change, in cult: 47.66 .127

chorus: 8.47 .66 .137

Christianity: 13. 51. 107. 145. 153. 160

citizen, privileges in cult: 75

commemoration: 4; of dedication: 1. 137; of priesthood: 83 
commemorative anniversary: 73

communication between mortals and gods: 44; see also s.v. dedication upon divine command confession inscription: 1

consecration of building: 90

contest, material rewards for winners: 69; see also s.v. festival

continuity: 6

cow: 122.137

creation of the world: 64

crown, crowning: 8. 20-21. 58. 62. 69. 73. 133. 155; of grave: 137

cult, foundation of: 3. 69; funding of: 53. 69. 158; promotion by kings: 10; transfer: 10; see also s.v. deification, funerary cult, imperial cult, ruler cult

cult personnel: 29 (in Eleusis); aethlothetas 137; agonarchos 137; agonothetes 21. 48. 62. 69. 90. 109. 137. 142. 145. 149; amphipolos 124; amphithales 69; archiereia (high priestess): 19. 69; archiereus (high priest): 5. 69. 109. 137; of Asia: 69; Asiarches 43, 69; of Cyprus: 85; of Lykia (Lykiarches): 90. 109; of Thrace/Thrakarches: 142; dadouchos 33; eisagogeus 69; epi bomoi 33; epimeletes naon 137; Eumolpidai 30; grammatistes hieron 137; bieragogos 109; bierarches 137; bieraules 48; bierodoulos 70; bierokeryx 33. 109; bieromnemon 40. 137; bierophantes 33. 48. 137. 145; hierophylax 13; hieropoios 155; hierotamias 5; hierothytes 40; bydrophoros 69; hypochrestes 69; hypophetes 47; katochos 35; Kerykes 30; kistiokosmos 149; kotarchos 69; leitoria 50; mantiarches 90; molpoi 66; panegyriarches 69. 145; pater nomimos 12; prokitharistes 69; prophetes 47. 59. 69. 122. 137; propolos 69; pyrphoros 33. 69. 137; pytharchis 69; tamias 137; theokolos 40. 136; theopropos 47; thespiodos 47; thytes 137; zakoros 48. 137; accumulation of offices: 20. 69; for life: 47; see also s.v. priest

cult regulation: 26. 49. 53. 66. 69. 109. 118. 122. 134. 136-138. 149

curse, tablet: 10-11. 40. 62. 81-82. 151-152; see also s.v. funerary imprecation, Greek words

death: 13. 90. 96. 101; see also s.v. afterlife

dedication, after an oracle: 69; after war victory: 136; on behalf of an emperor/king: 4. 35. 46. 130. 141; thanksgiving: 1. 69; upon divine command: 1. 3. 5. 24. 70. 109. 137. 143; for the wellbeing of family members: 5; see also Greek words

dedication, by a board of magistrates: 74. 76. 90. 125. 138; by family: 1. 40; by magistrate: 109 . 137; by a priest/cult official: 52. 59. 70. 83. 136-137; after the end of service: 5. 70. 109 . 137; by slave: 70; by soldier(s): 62. 94; by winner of contest: 48. 69. 109. 129?

dedication, of cauldron: 137; of honorary statue: 109. 136-137; of an image of one deity to another: 1. 5. 50. 59. 70. 74; of individual: 1. 40?; of slave: 1; of snake (bronze): 136; of threptoi: 1; of tripod: 137; of war booty: 137; of weapon: 28

defixio: see s.v. curse tablet

deification: 137 (T. Statilius Taurus)

deities: Adonis: 10. Agathe Thea: 155. Agathos Daimon: 19. 70. 137. Aglauros: 97. 106. Amphitrite: 124. Anyalios: 136. Aphea: 62. Aphetos. 136. Aphrodite: 10. 19. 60. 93. 109. 136. 147. 159; Epilimenia 62; Euekoos 137; Euploia 72; Ourania 69; Pandemos 105; Pontia 105. Apollon: 17. 21. 31-32. 34. 44. 59. 66. 69. 102. 109. 121. 126. 130. 136-137. 159; Auleites 69; Daphnephorios 156-157; Delios 20; Delphinios 66. 69. 147. 159; Didymeus 66. 69; Geronthratas 32; Hylates 150; Iatros 159; Karneios 20. 122; Klarios 44. 47; Lairbenos 1; Lairmenos 1; Lykeios 50; Patroios 40. 62; Prostates 74; Ptoios 137; Pythios 110; Selinaios 121; Soter 69; Termintheus 69. Ares: 90. 147; Megistos 90. Artemis: 1. 13. 62. 69. 89. 91. 109. 136-137. 147. 149. 159; Agrotera 137; Amarysia 157; Aontia 136; Boulaia 69; Boulephoros 69; Delia 68, 69; Eileithyia 137; Epekoos 70; Ephesia 159; Epikrateia 91; Hegemone 137; Kithone 69; Klaria 44; Kynagos 1; Limnatis 149; Lochia 69. 137; 
Ourania 50; Phosphoros 50; Skiris 69; Pythie 69; Soteira 137. Asklepios: 20. 23. 50.70. 132. 136. 144; epekoos 70. Athena: 62. 71. 97. 137. 145. 147. 156-157; Alea 88; Assessia 69; Lindia 72; Polias 20. 69. Auxesia: 62. Basileus: 109. Charops: 137. Daimon: see s.v. Agathos Daimon. Daimones: 137. Demeter: 29. 34. 40. 45. 69-70. 81. 136137. 159; Achaia 137; Argasis 69; Chthonia 14; Eleusinia 137; Nike 69; Prostasia 137; Thesmophoros 22. Dionysos: 57. 62. 69-70. 94. 98. 137. 145. 154. 159; Bakechios 43; cf. 123; Bakchos 14; Propator 52; Soter 94. Dioskouroi: 8. 40. 61. 70. 88. 100. 136-137; epekooi 70; Euangelioi 70; Soteres 70. Dodeka Theoi: 20. 70. Echo: 5. Eileithyia: 8. 137. Elpides: 69?. Enyalios: 53. Enyo. 40. Epione: 20. Eros. 102. 137. Eumenides: 137. Ge: 109. 156. Hades: 13. 78. 87. 161. Hagnai Theai: 70. Hekate: 69. 138. Helikon: 137. Helios: 19. 35. 62. 69. 87. 102. 156; Adonis 10; Apollon 1; Lairmenos 1; Zeus 69. Hephaistos: 62. Hera: 69. 147; epekoos 70. Herakles: 7. 40. 62. 70. 88. 131. 136-137; Kallinikos 105. 159; Leuktriades 137. Hermes: 5. 69-70. 136-137. 159; Agathos 159; Agoraios 76; epekoos 70. Hestia: 106; Sebaste 69. Homonoia. 19. 48. 137. Hosion kai Dikaion: 70. Hosios (kai) Dikaios: 70. Hygieia: 19?. 20. Iaso: 45. Iatros: 45. Ino: 96. Kabeiroi: 69. Kairoi: 69. Kore: 29. 34. 40. 45. 69-70. 137. Kouretes: 69; cf. 6. Kourotrophos: 69. Leto: 8. 69. 109-110. Leukathea: 40. Leukothea: 3-4. 54. Ma: 130. Megale Meter: 48. 137. Megale Thea. 159. Meiliche: 137. Melikertes: 3. Meter: 69. 109; Megale 48. 137; Oreia 14. Mneme: 102. Mnia: 62. Mnemosyne: 137. Muses: 69. 102. 137. Nemesis: 5. 69. Nereids: 124. Nike: 19. 74. 76. 102. 109. 136. Nymphs: 5. 55. 62. 67. 69. 136. 147. Palaimon: 81. Pan: 5. 59. 62. 137. 145. Persephone: 13. 40. Plouton: 102. Polykrates: 81. Poseidon: 19. 62. 109. 137. 147. 156; Asphaleios 69. 109; Helikonios 69; Orthosios 8. Rhea: 20. 145. Rhodos: 72. Rhome: 79. 109. 137. Thea: Hagne 70; Megale 159. Themis: 109. 137. Theoi: Chthonioi 9; Dodeka 20. 70; Olympioi 69; Pantes 69. 147. Theos Hypsistos: 69. Thetis: 124. Tyche: 20; Agathe 69. 108; Enoikidia 69. Welchanos: 6. 147. Zeus: 4-6. 35. 43. 62. 139. 156. 159; Agoraios 69; Aigiochos 69; Aitherios 69; Aithrios 137; Anolethros 69; Aphthitos 69; Apobaterios 69; Apotropaios 69; Arogos 69; Atabyrios 72; Chryasorios 138; Eleutherios 48; Elpidon 69?; Epineikios 141; Eumenes 36; Hedraios 109; Helios 69; Hellanios 34. 62; Hypatos 69; Hypsistos 69. 138; Idaios 35?; Idatas 147; Ithomatas 149; Karaios 137; Kataibates 69; Keraunios 69; Kodopas 141; Kronion 69; Ktesios 69. 137; Labraundos 69. 73; Larasios 69; Lepsynos 69; Megistos 69; Meilichios 69. 136-137; Nineudios 43; Olympios 34. 69. 109. 137; Osogo 73; Ourios 118 ; Pan 5; Panamaros 138; Pasios 62. 134; Patroios 5. 109. 159; Philetairos 159; Philios 159; Phratrios 83; Pisaios 69; Polieus 20. 109; Soter 8. 69. 109. 127. 159; Thenatas 147; Tropaiouchos 141; Xenios 109.

deities, Anatolian: Alandros 90; Herakasbos 70?; Kakasbos 70; Rider Gods 70. 90; Egyptian: 10. 16. 19. 35. 45. 69. 77. 109. 119. 136-137. 143; Oriental: 3. 5; Agdistis 70 (Angdeisis); Atargatis 5; Iupiter Dolichenus 46; Lenkothea 3; Melikertes 3; Mithras 12; Theandrios 5; Thea Syria 5; Roman: Stata Mater 136; Venus Augusta 136

deity, birth of: 6. 69; as eponymous magistrate: 69; as mediator: 3; patron of sailors: 61; patron of winds: 136; recipient of bequest: 60

devotion: 1.5

Dionysiac artists: 38.52 .69

divination: 5. 44. 47. 64. 69

diviner: 13

dog: 53

dream: 5. 96. 109. 137

dress, in celebration: 20; prohibition concerning dress: 136

dressing of statue: 97.106 
eagle: 43

ear, represented in relief: 69

Eleusinian mysteries: 13. 29-30. 33. 137. 145

elite: 47. 84. 86. 145

emotions: see s.v. hope

emperor: see s.v. imperial cult

endowment: 20.109.137. 149

epiphany: 44

epithets, list of: 69

exclusion from sanctuary: 5. 30. 38

exorcism: 51.160

expense, for cult: 8

family, connection with a cult or cult place: 4

fate(s): 13.62. 90

fertility: 26. 107. 109. 159

festival: 136; dramatic: 148; expansion: 63. 137; expense for: 8. 21; interrupted by war: 44; re-organisation: 44. 137; revenues from: 137; upgrading: 69

festival: Anakia: 127; Damatria: 136 (Dyme); Eileithyiaia 8 (Delos); Heraia: 138 (Panamara); Heroxeinia: 49 (Thasos); Kallynteria: 97; Katasporia: 109; Komyria: 138 (Panamara); New Year: 66; Panamia: 137 (Thespiai); Panathenaia: 56. 145. 158; Posideia: 8 (Delos); Taureia: 70 (Labraunda); Thoia: 137 (Thespiai); Tycheia: 20 (Kos)

festival, agonistic: 48. 56. 84. 87. 109. 159; in Thrace: 2. 142; Aktia: 2 (Perinthos). 25. 69 (Nikopolis); Antoneia: 48; Antoniniana Sebasta: 2 (Byzantion); Asklepieia: 2 (Philippi). 63 (Kos); Aspis: 69; Attaleia: 62 (Aigina); Balbilleia: 69; Chloia: 29; Darzaleia: 2; Delia: 21. 109; Didymeia: 69; Dionysia: 62 (Aigina). 69 (Miletos). 98 (Athens). 109 (Smyrna). 149 (Messene); Eleusinia: 29. 48; Eleutheria: 69; Erotideia: 137; Eumeneia: 62 (Aigina); Hadrianeia: 56 (Ephesos); Hadrianeia Epibateria: 52 (Erythrai); Hadriania: 2 (Coelum); Halieia: 58; Haloa: 29; Hemeresia: 136; Heraia: 69; Herakleia: 62 (Aigina). 137 (Thespiai); Isthmia: 56. 69; Kaisareia: 69 (Isthmia); Kalamaia: 29; Kapitolia: 69; Kendreisia 2; Klaria: 44; Koina Asias: 56. 69; Mouseia: 69. 137; Nemea: 69. 87. 109. 120; Nikephoria: 62 (Aigina); Olympia: 149; Pamboiotia: 137; Panathenaia: 56; Proerosia: 29; Ptolemaia: 109; Pythia: 2 (Thrace). 38 (Tralleis). 56 (Delphi). 69 (Ephesos, Tralleis). 116 (Attouda); Rhomaia: 62 (Aigina); Sebasta: 69; Severeia: 2 (Perinthos); Severia Nymphia: 2 (Anchialos); Sylleia: 136; themis: 90 (Boubon)

finances: 5. 18. 21. 53

foundation of cult: 69. 139; of sanctuary: 109

founder, of cult: 3 . 141; of city: 73

funeral: 41. 109-110

funerary cult: 4. 13. 19-20. 40-41. 48-49. 62. 87. 90. 96. 99. 137. 140

funerary imprecation: 13. 62. 137. 145

gem: 162

gladiatorial combat: 20.69.138

gratitude: 20.69.94

grave: see s.v. boundary stone, funerary cult

grove: 59

hair offering: 138 
hand, votive: 27

healing: 1. 51.144. 162

hero: Achilles: 72. 124; Aiakos: 62; Aigeus: 136; Herois: 137; Ion: 126; Kastorides: 137;

Kolon: 137; Kydon: 126; Polystratos: 136; Prokles: 137; see also s.v. deities/Herakles heroic cult: $62.80 .136-137$

heroisation: 41. 49. 62. 80

historiola: 62

Homer: 47

hope: 69

hymn: 6.73

bymnodos: 44

imperial cult: 2. 20. 29. 43. 52. 62. 69. 79. 84-85. 90. 136. 142. 146. 149; emperor identified with god: 52 (Hadrian/Neos Dionysos). 62 (Caracalla?/Neos Dionysos). 69 (Drusilla/Aphrodite, Hadrian/Zeus Olympios). 84

impurity: 51

incense-burner: 136

incubation: 144

initiation: 4. 5. 30. 38. 47. 57-58. 66. 154

innovation in cult: 47.66

inventory, of sanctuary: 62. 69.135. 137

justice: 81

kid: 53

kinship, mythical: 62.126

Kouretes: 6.69

lamp: 5.21

land, sacred: 115.137 ; donation of: 137

Late Antiquity, paganism in: 62. 145

lex sacra: see s.v. cult regulation

libation: 48

magic: 11. 16. 27-28. 51. 62. 81. 107. 145. 147. 153. 160. 162; see also s.v. amulet, Greek words manumission, sacred: 1. 121. 137

mask: 58

messenger, divine: 3

Minoan religion: 6

miracle, healing: 144

mystery cult: 13. 47. 58. 109; see also s.v. Eleusinian mysteries, Greek words

myth: 37. 43-44. 62. 69. 88. 109. 136. 145; mythical kinship: 62

nail: 101

name, theophoric: 19. 37; inspired by cult office: 19 (Hieratikos); inspired by myth: 37; quarter named after god: 40. 109; tribes named after heroes: 109

Neoplatonic philosophy: 145

number, nine: 140

oath: 5. 21. 66. 69. 90. 95. 117. 136-137.147. 156

oracle: 5. 44. 47. 65. 69. 90. 96. 108-109. 114. 137; criticism on: 64; reliability of: 69 
Orphics: 14-15. 57. 101.136. 154

ox: 122

perirhanterion: 69

personification: 69

piety: 1. 20. 47. 65. 72. 108. 137; see also Greek words

pilgrimage: 38.44 .47 .86 .109

prayer: 1. 5. 10. 22. 35. 46. 50. 54. 69. 106. 152; prayer for justice: 81 ; failed prayer: 137 ; see also Greek words

priest: 5. 43-44. 47-48. 52. 62. 69. 83. 90. 97. 106. 109. 137-139. 145. 150. 155; priestess: 5. 19-20. 48. 69-70. 80. 90. 97. 109. 137-138; eponymous: 40. 109; family of: 5. 85. 145; accumulation of offices: 20. 69; couple serving as p.: 70. 90.109; hereditary: 119; for life: 47. 69. 137; iteration: 19.137-138; list of: 139; qualification for: 50; perquisites: 26. 39. 69; revenues of: 5; sale of: 39. 69.105. 118 priesthood; selected through oracle: 69; serving हैं छ̇ $\pi \alpha \nu \gamma \varepsilon \lambda i \alpha \varsigma$ 138; see also s.v. cult personnel, dedication

procession: 21. 66. 69.73; carrying of divine images: 5

propitiation: 109

prostration: 70

purification: 8.30 .40 .156

Pythais: 86

rider god: 70

ritual: see s.v. banquet, crowning, dressing of statue, hair offering, incubation, initiation, libation, manumission, oath, pilgrimage, prayer, procession, propitiation, prostration, purification, Pythais, rosalia, sacrifice, supplication, taurobolium, theoria, throne (decoration of), vow; see also Greek words

rosalia: 20

ruler cult: 62.69 .73 .84 .109 .111 .150

sacrifice: 8. 20-21. 26. 30. 39. 44. 49. 62. 66. 69. 73. 75. 90. 106. 122. 127. 137-138. 150. 156; bloodless: 113; distribution of meat: 42. 109; victim: 53. 122; see also s.v. animal, Greek words

sacrilege: 136

sanctuary, as bank: 109; building works: 137; on frontier: 136; on a road: 92 ; competition among s.: 47; exclusion from: 5; finances: 5. 21; foundation of: 109; order in: 91. 134; ownership of land: 115. 137; ownership of slaves: 1. 69-70. 121; propaganda: 135; publication of documents: 69.73. 75. 109. 136. 156; recipient of bequest: 60; recipient of fines: 1. 156; see also s.v. account, inventory

sheep: 122

sign, divine: 44

slave, dedicant: 70 ; initiation of: 38; of a god (metaphorically): 5; owned by sanctuary: 69; participation in banquet: 62; hierodoulos: 70

snake: 100.136

soldier, payment of cult-tax: 53

Solomon, in magic: 27-28. 55. 112

soul: 13.137 .145

statue, cult: 62. 97. 106; dressing of: 97. 106; dedicatory, of exactly the same size as an individual: 68

supplication, limits of: 156 
taurobolium: 145

tax, for cult: 53.109. 122

theft of sacred property: 136

theoria, theoros: 21. 26. 38. 44. 63.69.109. 137

throne, decoration of: 155

tithe: 40.69

torch: 21.155

trees, planting of: 109.133

truce: 73

uterine magic: 147.162

voodoo doll: 11

vow: 1. 5. 9. 35. 43. 46. 50. 68-70. 90. 113. 130.137-138. 141

vowels, sequence of: 28

war, impact on religion: 44

wind: 136

women: 136

wreath: see s.v. crown

youth: 47. 66. 138

\section{Greek words (a selection)}

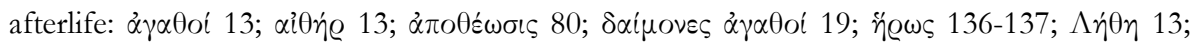

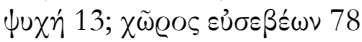

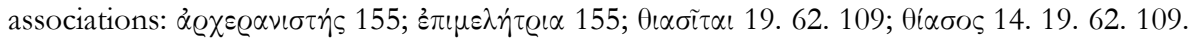

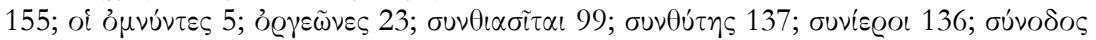
137. 155

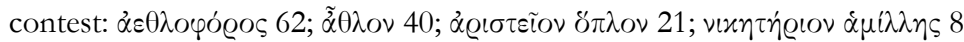

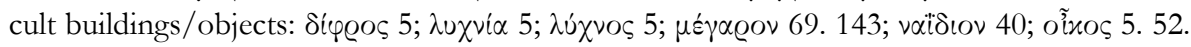

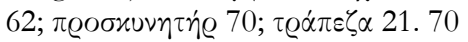

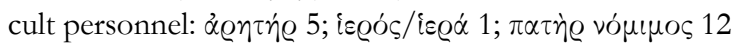

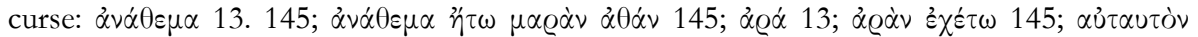

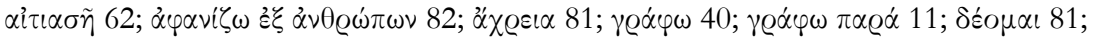

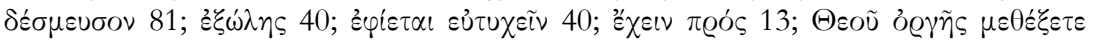

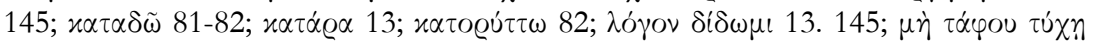

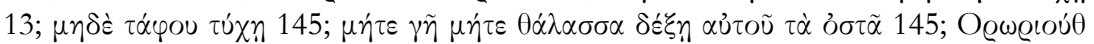

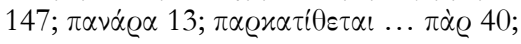

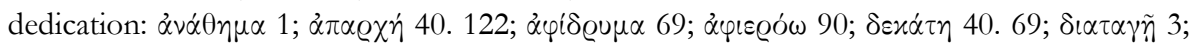

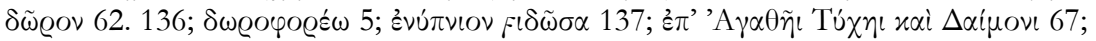

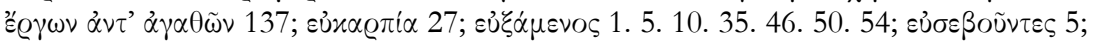

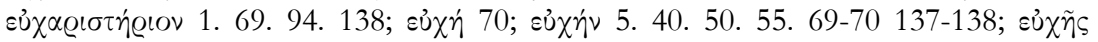

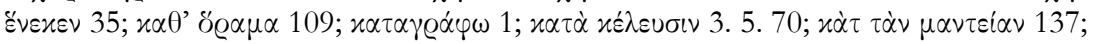

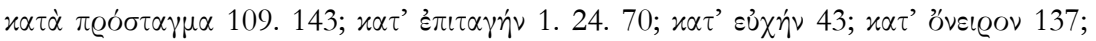

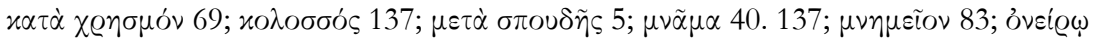

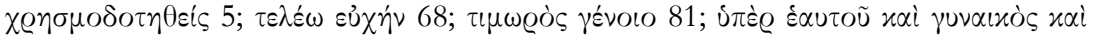

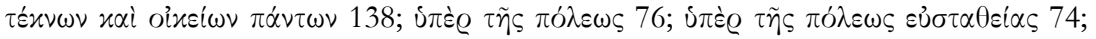

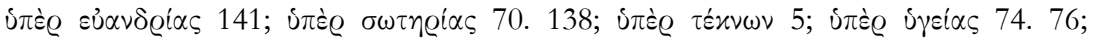

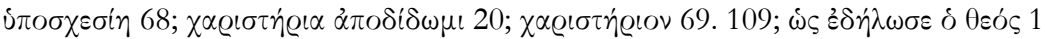




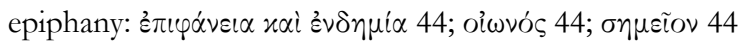

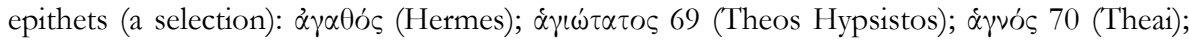

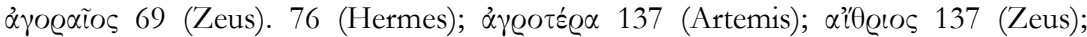

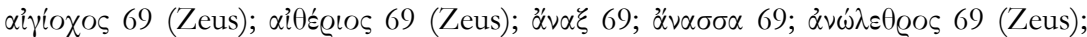

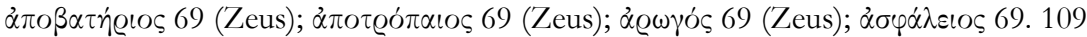

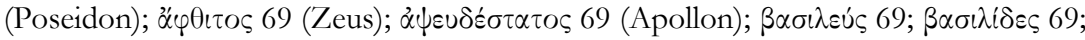

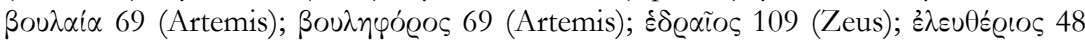

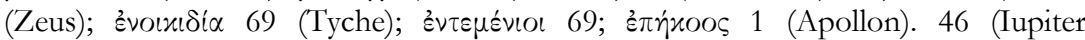
Dolichenus). 62 (an emperor). 69 (Horus, Zeus). 70 (Angdeisis, Artemis, Asklepios,

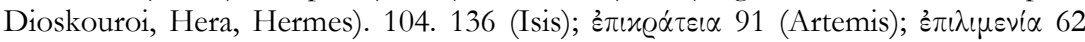

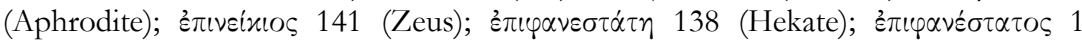

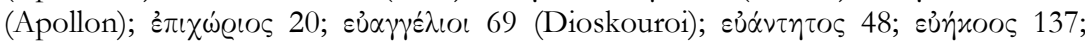

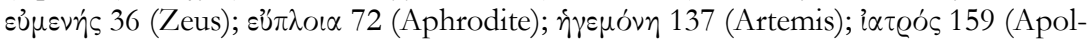

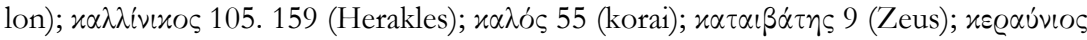

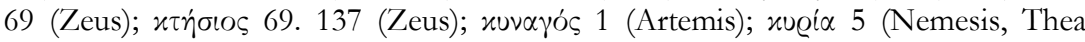

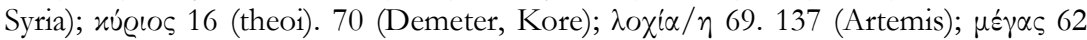

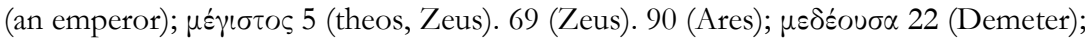

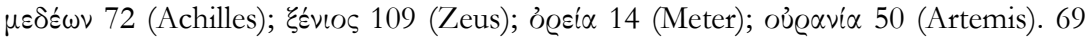

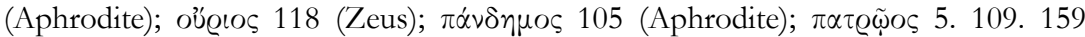

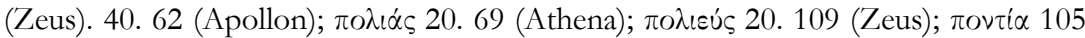

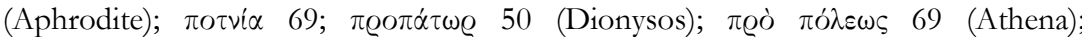

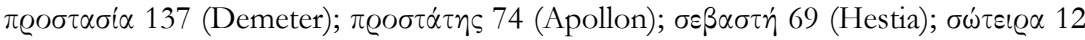

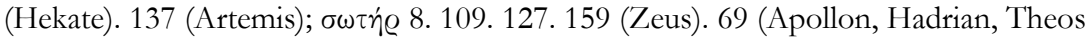
Hypsistos, Zeus). 70 (Dioskouroi). 94 (Dionysos). 111 (Antigonos, Philip); ப̈ $\pi \alpha \tau$

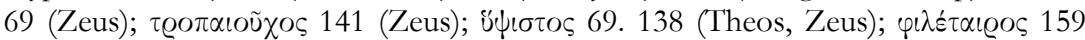

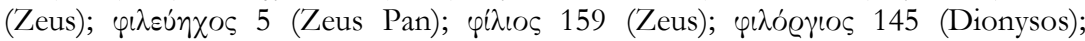

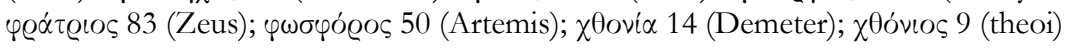

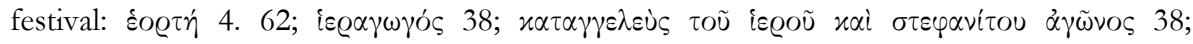
$\lambda \varepsilon \cup \chi$ น

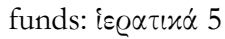

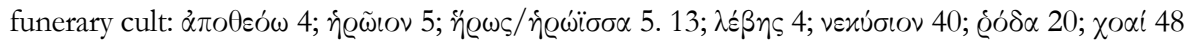

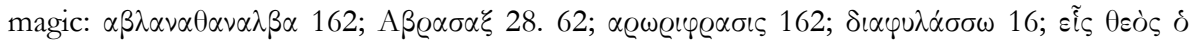

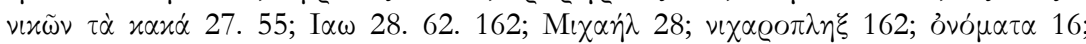

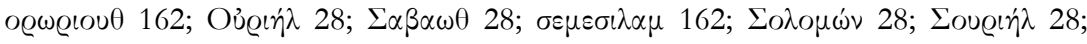

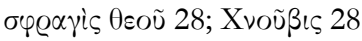

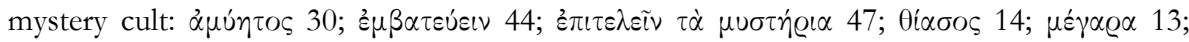

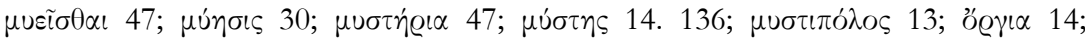

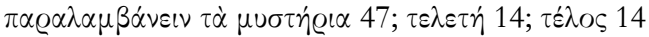

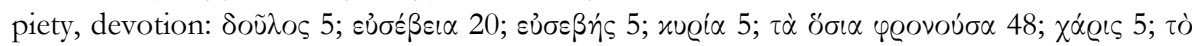

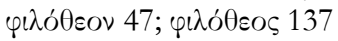

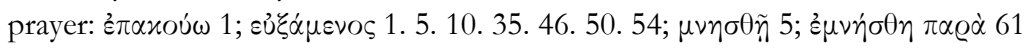

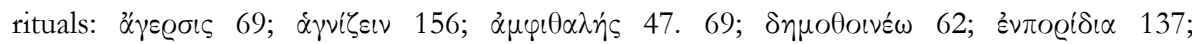

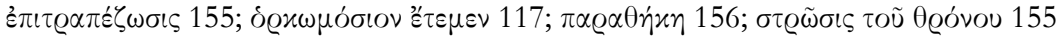

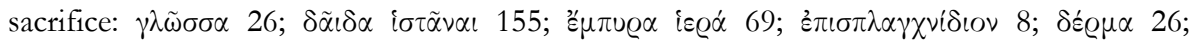

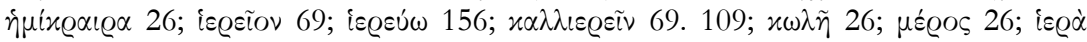

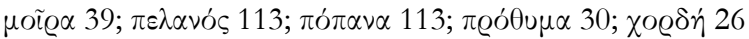


1) E. AKINCI ÖZTÜRK - C. TANRIVER, "New katagraphai and Dedications from the Sanctuary of Apollon Lairbenos”, EA 41 (2008), p. 91-111 [BE 2009, 483]: Ed. pr. of 23 new inscriptions from the sanctuary of Apollon Lairbenos northeast of Hierapolis ( $c f . E B G R$ 2000). They consist of dedications of slaves, threptoi, and free individuals (katagraphai: 1-3, 5-11, 13-18), dedications (4, 12, 19-22), and possibly a confession inscription (23). They all date to the Imperial period (c. 170-230 CE). The dedications of slaves (1, 13), threptoi (2, 5-11, 14-15), and

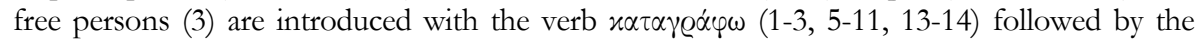
name of the god in the dative (Helios Apollon Lairmenos: 1, 2, 5, 7, 8, 14-15; Helios Apollon Lairbenos: 11; Apollon Lairmenos: 3, 13; Helios Apollon: 6; Helios Apollon Laimenos: 9). Some of the dedications of slaves took place upon divine command (1, 5: $x \alpha \tau^{\prime}$ ह $\pi \iota \tau \alpha \gamma \eta \dot{\eta} v ; 15: \omega \varsigma$

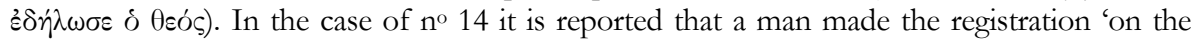

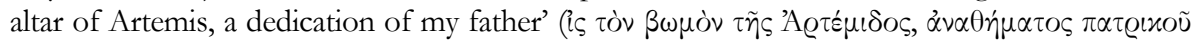
$\mu \mathrm{Ou}$ ) [for such cases of commemoration and emotional attachment see EBGR 2007, 30 bis; $c$. an inscription from Thespiai (infra $\mathrm{n}^{\circ}$ 137) that commemorates the fact that the ancestors of a priestess had dedicated a statue of Dionysos; cf. MAMA VIII 446: $\pi \varrho o \gamma o v \iota x \dot{\alpha} \alpha \nu \alpha \theta \dot{\eta} \mu \alpha \tau \alpha]$. The

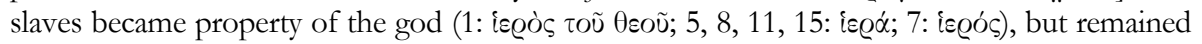
free. In one case, the dedicated individual was an alumna of a bieros and his wife, a biera (15). Fines, payable to the sanctuary (2), the sanctuary and the fiscus $(1,5-11,13-18)$, the sanctuary, the fiscus, and the city of Motella (3) were imposed on those who violated the act of

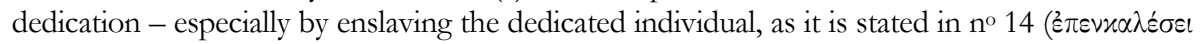

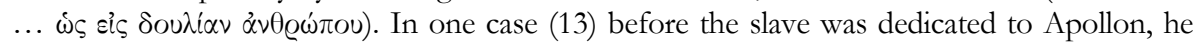
had been set free 'through the archives in Motella'. The free status of the dedicated individuals [from the perspective of secular law; see EBGR 2006, 121] is confirmed by the text $\mathrm{n}^{\circ} 14$

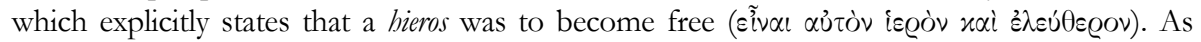
M. RicL ("Donations of Slaves and Freeborn Children to Deities in Roman Macedonia and Phrygia: A Reconsideration", Tyche 16 [2001], p. 155f.) has pointed out, "the master had first relinquished all his rights over the slave, then handed him over to the god and finally had him

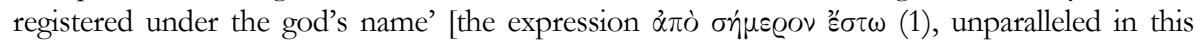
sanctuary, is often attested in manumissions]. The texts nos 2 and 7 are of particular interest, because the dedicants also bestowed a workshop, a house, and tools upon their dedicated threptoi ( $c$. EBGR 2000, $169 \mathrm{n}^{\circ}$ K43). It is assumed that the dedicated alumni run the business being accountable to the sanctuary. Dedications: A man from Hierapolis living at Mossyna dedicated to Helios Apollon Lairmenos émríxoos $\theta \varepsilon o ́ \varsigma$ a statue, together with his wife and

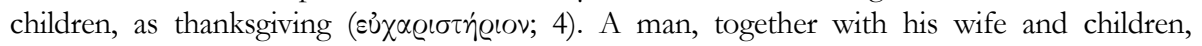

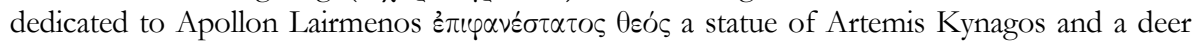
together with its base (12). A man from Motellokepos dedicated an intercolumnium to

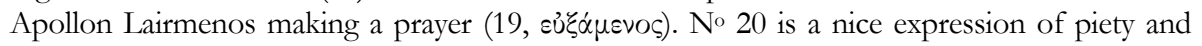
devotion: 'I Apphia, daughter of Alexandros, from Motella, after having become ... set this up

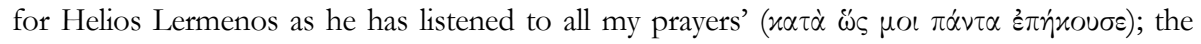
scribe seems to have forgotten a word (e.g. 'after having become healthy'). Another dedication to Apollon Lairmenos was made in fulfilment of a vow (21). It is not clear if $n^{\circ} 24$ is a

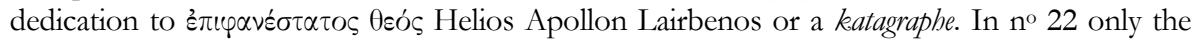
epithet Larbenos is preserved; no 25 is a small fragment. The authors interpret $n^{\circ} 23$ as a confession inscription, restoring [ ('after having been punished by the god Helios Apollon Lairbenos) [but other verbs (e.g. $[\sigma \omega \theta] \varepsilon i \zeta$ or $[i \alpha \theta] \varepsilon i \zeta)$ can be restored, in which cases the text is a dedication].

2) E. AlbAnidis - S. GiATsis, “Athletic Games in Thrace During the Imperial Era”, Nikephoros 20 (2007), p. 177-197 [BE 2009, 327]: A.-G. give an overview of the various agonistic festivals held in Thrace in honour of deities and Roman emperors: Philippopolis: Pythia, Kendreisia; 
Perinthos: Pythia, Aktia, Severeia; Byzantion: Antoniniana Sebasta; Anchialos: Severia Nymphia; Odessos: Darzaleia; Coelum: Hadriania; Philippi: Great Asklepieia; Serdica: Pythia.

3) J. Aliquot, "Inscriptions grecques et antiquités de Haloua", BAAL 8 (2004), p. 301-314 [BE 2006, 465; SEG LIV 1630]: Ed. pr. of an interesting dedication from Haloua (Mt. Hermon, territory of Sidon). The dedication to a local god was made upon the divine command of a local god, which was transmitted to the worshipper through the mediation of another god:

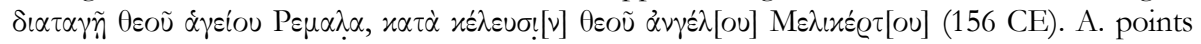
out that the word $\delta\llcorner\alpha \tau \gamma \eta \dot{\eta}$, common in the New Testament, was hitherto unattested in a pagan

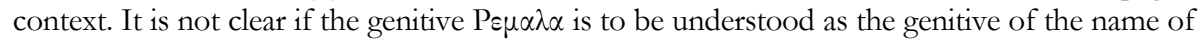
the cult founder ('god of Remalas') or as a toponym. Another Phoenician dedication in the area of 'Tyre refers to an 'angel god of Milkashtar'. In the new text, one observes a conflation of Melikertes with his angel. Thus, Melikertes occupied a position between the great local god (the god of Remala) and his worshippers [for the concept of a hierarchy of gods in this period see A. CHAniotis, "Megatheism: The Search for the Almighty God and the Competition of Cults", in S. Mitchell - P. van Nuffelen (eds.), One God: Pagan Monotheism in the Roman Empire, Cambridge, 2010, 112-140]. A. discusses the cult of Melikertes and Leukothea in this area and the belief in divine messengers.

4) J. AliquOT, “Leucothéa de Stageira”, Syria 79 (2002) [2004], p. 231-248 [SEG LII 1587]: A. republishes a very interesting dedication to Leukothea on behalf of the Emperor Trajan from 'Ayn al-Burj (ancient Segeira; OGIS 611; IGR III 1075). The dedication was made by an

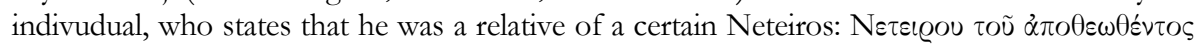
$\varepsilon^{2} \nu \tau \tilde{\varphi} \lambda \hat{\varepsilon} \beta \eta \tau$. The interpretation of this phrase has been the subject of a long controversy. More recently, M. SARTRE ("Faits divers et histoire des mentalités : à propos de quelques noyés et de trois petits cochons", Syria 70 [1993], p. 51-67) interpreted it as a reference to the accidental death of a boy, which was considered a sign of divine election, whereas C. BONNET ("De l'histoire des mentalités à l'histoire des religions : à propos de Leucothéa et de trois petits cochons", Studi epigrafici e linguistici sul vicino oriente antica 14 [1997], p. 91-104) thought of an initiation rite modeled on the myth of Melikertes, who was immersed by Leukothea in a cauldron; the rite was understood as the symbolic death and divine rebirth of the initiate Neteiros. But as A. points out, in the Imperial period $\alpha \pi \circ \theta \varepsilon o ́ \omega$ can also have the meaning 'to die' or 'to be buried', with the additional connotation 'to receive funerary honours' (e.g. SEG

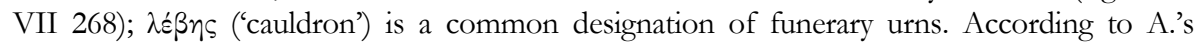
interpretation, Neteiros received funerary honors and was buried in a lebes. The phrase $\delta \imath^{\prime}$ o $\tilde{u} \alpha i$

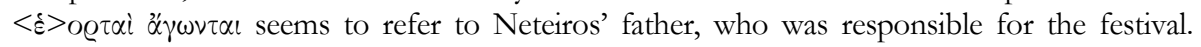
Menneas, who supervised the building activities at that site, recorded his family's connection with the sanctuary, in which a family member was buried. In Syria, epitaphs can be perceived as dedications to the gods ( $c f$. SEG XXXVII 1538 = MERKELBACH-STAubER, SGO IV $21 / 24 / 02)$; the grave of Neteiros was an annex to the nearby temple of Zeus.

5) J. Aliquot, Inscriptions Grecques et Latines de la Syrie. Vol. 11, Mont Hermon (Liban et Syrie), Beirut, 2008 [BE 2009, 512]: Corpus of the inscriptions from the area of Mt. Hermon. New texts are marked with an asterisk. West Hermon. Haloua: For the dedication to the god Remalas (1) see supra no 3. Deir el-Aachaiyer: An inscription commemorates the construction of a diphros during the term of Beeliabos as a high priest of the gods of Kinoreia (4); the diphros, a sort of throne, may have been used for the carrying of divine images in processions. Kfar Qouq:

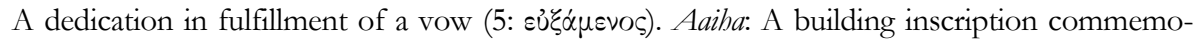
rates the erection of a building during the term of a priest; the building was constructed with

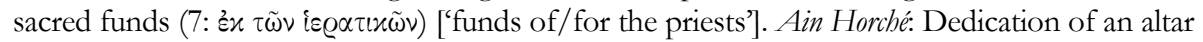

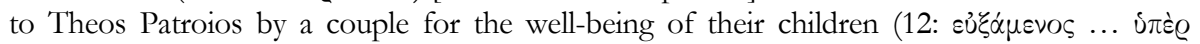




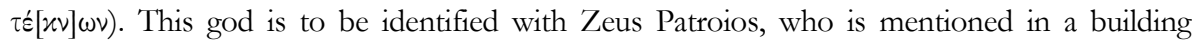
inscription (14). A commemorative inscription for a priest ( $\mu \nu \eta \sigma \theta \tilde{n} . .$. iє@єús) is engraved on a rock in front of the temple. Ain Aata: Two epitaphs of Iulius Kanthouros, priest of a god and a goddess, whose names are not preserved $(15, * 16)$ [in 16 , read $\theta \varepsilon \tilde{\alpha} \varsigma$, not $\theta \varepsilon \dot{\alpha} \varsigma]$. El-Habbariye: A dedication on behalf of emperors (17).

East Hermon. Jdeidet Yabous: Reference to a priest in a dedication or building inscription (*19). Rakblé: Numerous inscriptions, mostly referring to construction work, were found in the sanctuary of Leukothea. The goddess is named in some texts (21: Leukothea; 22: Thea Leukothea Rachlas), in others she is referred to as 'the goddess' $(22,27 ;$ cf. 20: Thea Moithou, 'the goddess of Moithos'). The texts illuminate the financial administration of the sanctuary, by referring to the office of the 'sacred treasurers' (bierotamiai). The bierotamiai $(23,28)$, the priest $(* 22 ;$ cf. 25,29$)$, or jointly a bierotamias and a priest $(24)$, supervised the building works, which consisted of the erection or restauration of an oikos (*22), a door (23), a wall with three niches (27), a porticus (28). The constructions were funded 'from the funds of the goddess' (27: $\varepsilon x$

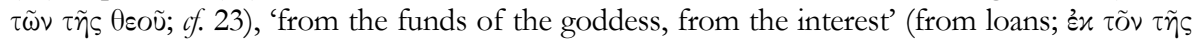

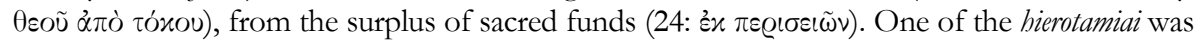
the son of a priest (23). Construction of a wall with three niches was under the responsibility of a priest. Two private dedicatory inscriptions were found in another sanctuary $(* 31,32$; 'sanctuaire ouest'). One of the dedications is interesting because the usual formula 'he/they dedicated' is supplemented with the phrase 'with zeal' (*31: $\mu \varepsilon \tau \dot{\alpha} \sigma \pi \circ \delta \delta \tilde{\eta} \varsigma)$, thus highlighting the dedicants' devotion. Two further dedications were not found in situ. One of them was made upon divine command (*34: $x \alpha \tau \dot{\alpha} x \varepsilon \dot{\varepsilon} \lambda \varepsilon \cup \sigma \nu)$. The second text is engraved on a bronze lamp and commemorates the dedication of a lychnia ('lampadaire') and a lychnos to Leukothea (35). Qalaat Jendal: A priest together with his wife and children dedicated a niche to Zeus

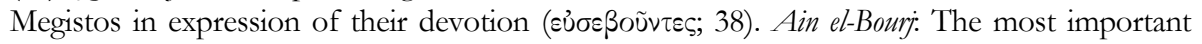
text is the well-known dedication of Menneas to Leukothea of Stageira (39), for which see supra no 4. Qasr Antar: A stele was dedicated to a Theos Megistos (40), probably Baal of Mt. Hermon, upon his command ( $x \alpha \tau \dot{\alpha} x \varepsilon \dot{\lambda} \varepsilon v \sigma \iota \nu)$, by a group designated as 'those who take the

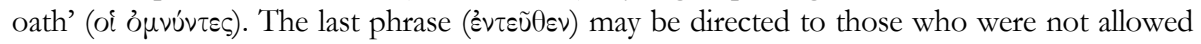
to enter the sacred place ('go away from here'). It has been suggested that the oath may be related to an initiatory cult or an association. A. discusses the possible association of this text with the apocryphal Book of Henoch, which narrates of the descent of 200 angels on Mt. Hermon and commiting themselves under oath to the corruption of mankind. Rimé: A dedication of a temple for Theos Andrios (sc. Theandrios, Theandrites; 41). Amé: A text commemorates the decoration of a temple of Zeus of the village of Ornea (42) and of other

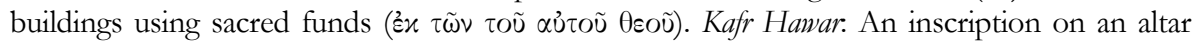
commemorates the devotion of a certain Lucius from Akraba to Thea Syria Hierapoliton (A),

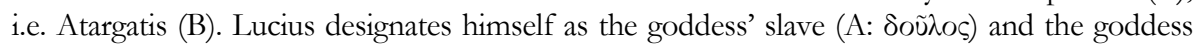
as his mistress (B: xugi $\alpha$ ). He reports that he dedicated an altar, coming to this place twenty

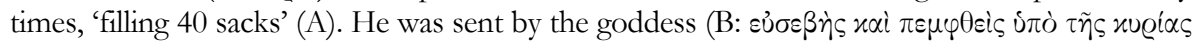

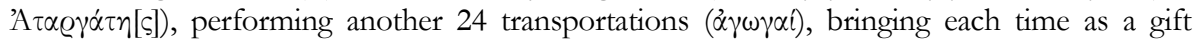

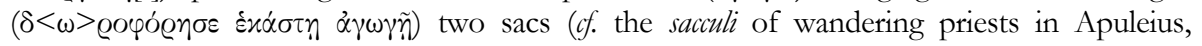
Metamorphoses VIII, 28). Hiné: An inscription commemorates the construction of a peribolos and another building. The construction was funded $\dot{\varepsilon} x \tau \tilde{\omega} \nu i[\varepsilon \varrho] \alpha \tau i[x] \tilde{\omega} \nu \pi[\varrho \circ] \sigma o ́ \delta \omega \nu$ ('sur les revenus du trésor sacré') [more acurately: 'from the priestly revenues']. Another inscription

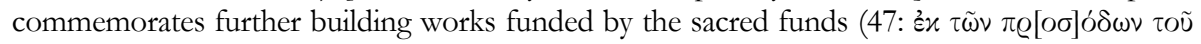
$\theta \varepsilon o \tilde{u})$; the supervisors of the constrution advanced the money $([\pi \varrho] \circ[\alpha]<\nu>\eta \lambda \dot{\omega} \sigma \alpha \nu \tau \varepsilon \varsigma)$ [if we restore $([\pi \varrho] o[\sigma \alpha]<\nu>\eta \lambda \omega \dot{\omega} \sigma \alpha \nu \tau \varepsilon \varsigma$, they paid part of the expenses]. A basin was dedicated by a 
sacred treasurer (hierotamias, 52). Beit Saber: A dedication was made by a priest after the end of his service (*54: iø@ó $\sigma \alpha \varsigma)$.

In an Appendix, A. presents the inscriptions from south Hermon. Qalaat Boustra: A dedication or construction is dated with reference to a priestess (A1). Har Senaim: see infra no 35. Tel Dan: Dedication to Theos ho en Danois by Zoilos in fulfilment of a vow (A12: sưviv) [EBGR 1992, 227]. Kaisareia-Paneas: For a group of dedications to an anonymous god of Panias (A1-A12) see

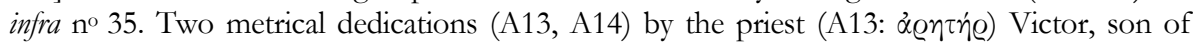
Lysimachos commemorate his dedications (148 CE). He dedicated a statue of a goddess (Maia, Echo or Nemesis) to Zeus Pan, 'who loves Echo' ( $\varphi \imath \lambda \varepsilon u \eta \dot{\chi} \chi \omega \Delta$ เó $\pi \alpha v \iota)$. The text is to be seen in the context of divination. The second dedication is addressed to Pan and the Nymphs; Lysimachos and his sons dedicated an image of Hermes, making a prayer ( $\sigma \cup v \varepsilon v \xi \dot{\alpha} \alpha \mu \varepsilon] \nu \circ \varsigma)$. A priest of Pan dedicated a statue of kyria Nemesis and her temple, with its decoration and an iron grille for the salvation of the emperors (A16). A magistrate dedicated together with his family a statue of kyria Echo, after receiving an oracular command in a dream (óví@ $\chi \varrho \eta \sigma \mu о \delta o[\tau \eta] \theta \varepsilon i \xi ; ~ A 17,221 \mathrm{CE})$. A fragmentary dedication for the salvation of the emperors (A18) refers to gratitude ( $\chi \dot{\alpha} \varrho \iota \varsigma)$. Another fragmentary dedication $(* A 19)$ probably mentions a

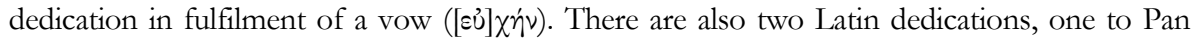
(A15), the other pro salute of Elagabal (A21).

Afterlife: We note the use of the term $\dot{\eta} \varrho \tilde{\omega} \iota \mathrm{v}$ for the grave $(8,9,11)$ and of $\ddot{\eta} \varrho \omega \varsigma$, $\varrho \omega \ddot{i} \sigma \sigma \alpha(36)$ for the deceased individual.

6) M. Alonge, "The Palaikastro Hymn and the Modern Myth of the Cretan Zeus", in Mikros Hieromnemon, p. 229-249: The famous hymn of Zeus from Palaikastro has often been used by the proponents of the theory of cult continuity from Minoan to post-Minoan Crete. A. points to the weaknesses of this theory and of the perception of Cretan Zeus as a successor of a Minoan fertility god. A recently published treaty oath from Eleutherna (SEG LIV 841; infra $n^{\circ} 147$ ) shows that Zeus and Welchanos, an indigenous god, were regarded as separate gods. A. understands the word noṽeos as a reference to the baby Zeus. Although he does not think that Zeus was worshipped as a baby at Palaikastro, he interprets the hymn as a 'hymn to a baby Zeus' commemorating the god's first arrival to Crete; the dancers who performed it may have impersonated the Kouretes.

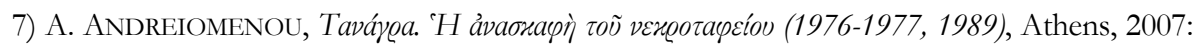
In her report on the excavation of the cemetery at Tanagra, A. presents 73 graffiti and dipinti on vases (usually on kantharoi) found in the deposit of a sanctuary of Herakles (p. 31-46; 5th-

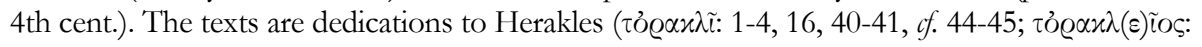

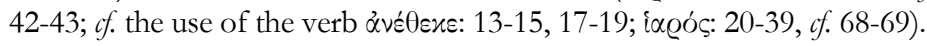

8) C. AntonetTi, "Un frammento inedito dei rendiconti degli ieropi di Delo", in G. CResCI Marrone - A. Pistellazo (eds), Studi in ricordo di Fulviomario Broilo. Atti del Convegno, Venezia, 14-15 ottobre 2005, Padova, 2007, p. 9-23 [BE 2008, 451]: Ed. pr. of a fragmentary account of the Delian bieropoioi (c. 177) kept in a private collection. The preserved lines contain the

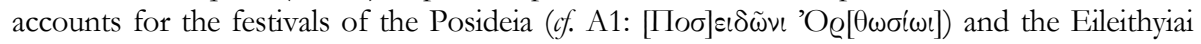

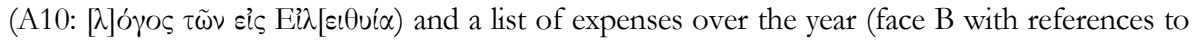
the months Galaxion, Artemision, Thargelion, and Panamos). The accounts refer to expenses for the purchase of various items (wine and other foodstuffs, tiles, sacrificial animals, oil,

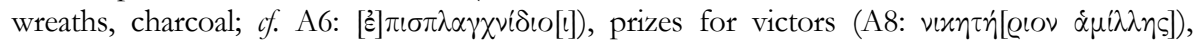
choruses (B 15), the purification of the sanctuary (B1, 22), and rites for Leto, Zeus Soter (B3), Eileithyia (B11), and the Dioskouroi (B18). 
9) R. Ardevan - V. Wollmann, "Eine griechische Inschrift aus Ilişua (Dakien)", in L. MihailesCu-BîRlibA - O. BOUnegru (eds), Studia historiae et religionis Daco-Romanae in honorem Silvii Sanie, Bucharest, 2006, p. 259-265 [BE 2008, 344]: Ed. pr. of a dedication found at Ilişua (Dacia), near the camp of the ala I Tungrorum Frontoniana (2nd cent. CE). Zamannisthes (a settler from Asia Minor) made a dedication to the Chthonian Gods in fulfilment of a vow [non vidimus, see A. Avram, BE 2008, 352].

10) P. Aupert, "Hélios, Adonis et magie : les trésors d'une citerne d'Amathonte (Inscriptions d'Amathonte VIII)", BCH 132 (2008), p. 347-387. Ed. pr. of two inscriptions found in a cistern near the north wall of Amathous. The first object is an inscribed wine jug

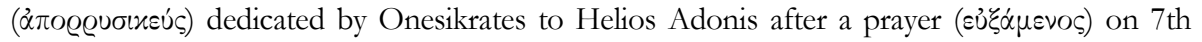
Rhomaios of 18 CE. A. discusses in detail the cult of Adonis and Aphrodite in Amathous, in association with the cult of Egyptian deities. The cult, originating in Byblos, was actively promoted by the Ptolemies. The new text provides evidence for solar syncretism in the early Imperial period. The second text is a defixio on a lead tablet dating to the 7 th cent. CE. A text is written on either side of the drawing of a man, covered with magical signs: (left) $\Delta \alpha \mu(\dot{\alpha}) \tau \varrho$

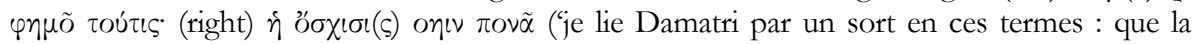
copulation (ou les bourses) oiin, lui fasse(nt) mal').

11) A. Avram - C. Chiriac - I. Matei, "Defixiones d'Istros", BCH 131 (2007) [2009], p. 383420: Ed. pr. of eight lead tablets with defixiones from Histria (4th cent.). The longest text (1) is a judicial defixio against Diogenes and those who supported him in a trial, possibly as

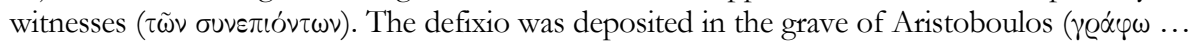

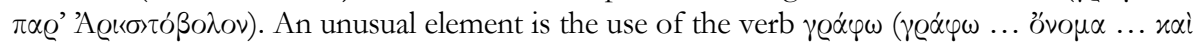

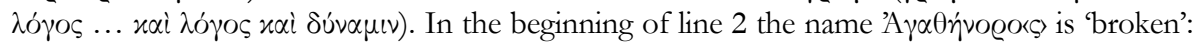
The scribe wrote ANOPO, adding $\Gamma A \Theta H$ between lines 1 and 2; the eds. suspect that this was done on purpose by the scribe, in order to destroy the name of one of his opponents ( $c$. SEG XLIX 322). [This is quite probable: in this way a name that contains $\alpha \gamma \alpha \theta$ ó into a name that conveys $\ddot{\alpha} \omega \varrho o \zeta]$. The other defixiones are addressed against groups of men $(2$, 4 ?) and men and women (3); two tablets are very fragmentary $(5,6)$, another one is illegible (7). The last text (8) is a name inscribed on the lid of a lead box which probably contained a voodoo doll; similar lead boxes have been discovered in Athens and Pantikapaion (for a list see p. 417-420). The authors present an annotated list of defixiones found in the area of the Black Sea (Olbia, Chersonesos, Pantikapaion, South Russia).

12) M. Bărbulescu - A. CÂteia, "Pater nomimos în cultul Hecatei la Tomis", Pontica 40 (2007), p. 245-253 [BE 2008, 369]: Ed. pr. of the epitaph of a man (Roman citizen), who bears

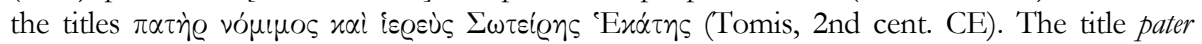
nomimos is attested in the context of the cult of Mithras in Aquileia (ILS 4251) and Sidon (SEG LII 1591-1593), in the latter city also in connection with the cult of Hekate. In Histria, the title was used by the priest of a cult association of Hekate.

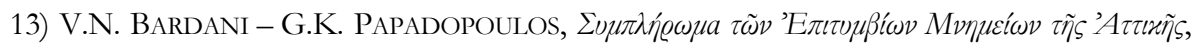
Athens, 2006: The authors present a collection of more than 3,400 grave inscriptions from Athens and Attika (mostly published) that have not been included in $I G \mathrm{II}^{2}$. Afterlife and death: Some grave epigrams are of interest in connection with ideas about death and afterlife. As is often the case in epigrams of the Hellenistic and Imperial period, several epigrams make a distinction between the body and the soul $(1206,1621,1923)$, claiming that the soul has joined

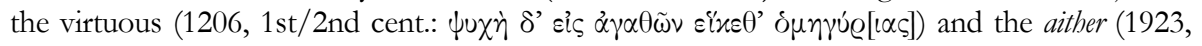

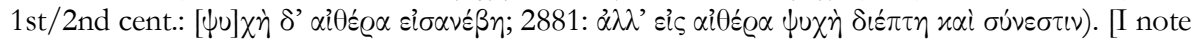
the expression $\alpha \gamma \alpha \theta \tilde{\omega} \nu \delta \mu \eta \dot{\gamma} \gamma \varrho \iota \varsigma$, which alludes to the belief that a privileged position in the

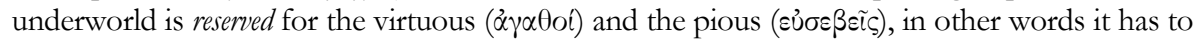


be earned through moral qualities - as opposed to the belief that this can be achieved through initiation and the automatism of a ritual; cf. EBGR 2000, 31.] Naturally, there are references to

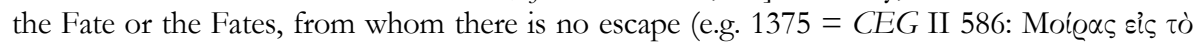

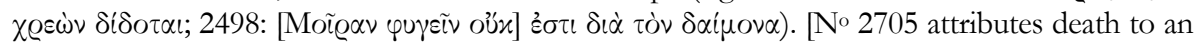

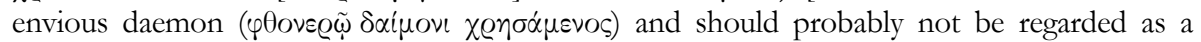
Christian epitaph; on this expression of. infra no 137.] Funerary practices: In an interesting epigram the deceased man is presented asserting that he was buried by the hands of his wife and

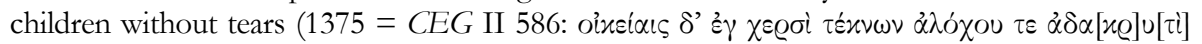

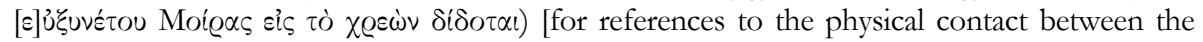
bereft and the deceased during the burial see EBGR 2006, 26].

The epigrams for two individuals who lived an exceptionally long life - a woman who died at the age of 90 (411 = CEG II 592, c. 300) and a man who reached 105 years (821, late 4th cent.) - highlight the fact that they went to their death happy and envied by others (411: $\varepsilon \dot{\jmath} \theta[\alpha] v \dot{\alpha} \tau \omega \varsigma$

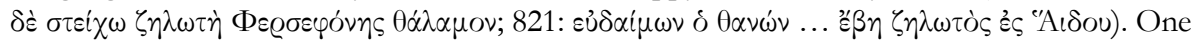
notes the different perspective of the underworld for the two genders: the epigram for the woman designates it as Phersephone's chamber, that for the man as the house of Hades. The epigram for the woman also presents her as confirming that her daughter had carried out the

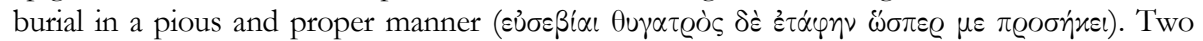
texts offer consolation. The underworld is a place free of grief (2617: 'may that place be free of

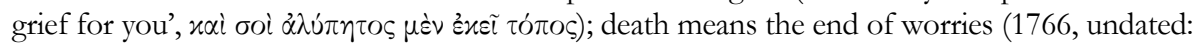

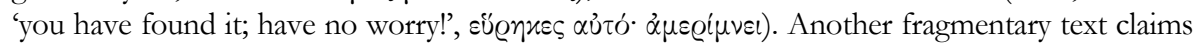
that the love of a husband shall be stronger than death; neither Acheron's cold water nor the drink of Lethe shall reduce his desire; according to the restoration, Persephone herself would

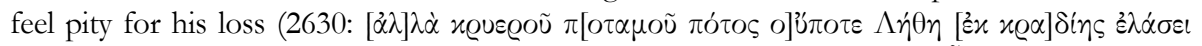

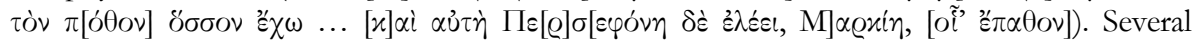
epitaphs were set up for cult officials or religious experts: an epigram for the diviner and soldier Kleiobolos (148 = CEG II 519, c. 375-350); a fragmentary text that mentions a

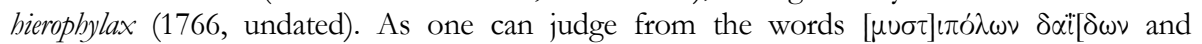
$\mu \varepsilon \gamma \alpha$ @oos in an epigram (2994 = IG III 1393), it must be related to the Eleusinian mysteries. No 2983 may be a dedication to Artemis and not an epitaph. There are numerous boundary

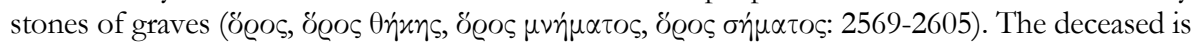
only rarely called heros $(2262,2959)$.

Funerary imprecations: Curses against the violators of graves only appear in Christian epitaphs. II list them here because of their affinity with pagan funerary imprecations (for which see

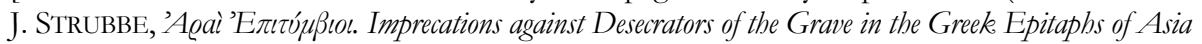
Minor. A Catalogue, Bonn, 1997). № 2747 [IG II $\left.{ }^{2} 13517\right]$ is an interesting case, as the reference

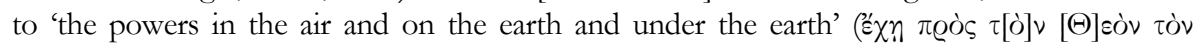

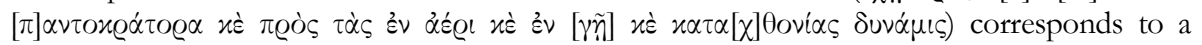

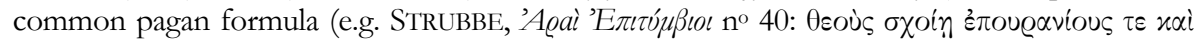

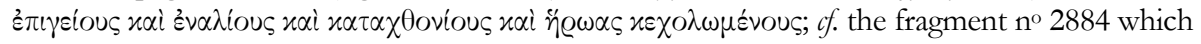

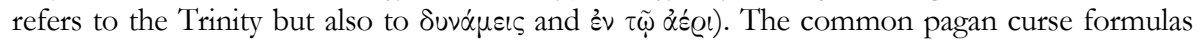

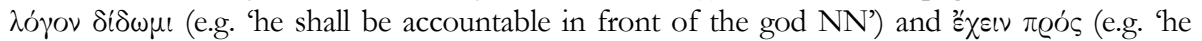
shall face the god NN') were adjusted to the belief in the Christian god (2665: $\lambda$ óyov $\delta \omega \sigma \eta \eta \tilde{\omega}$

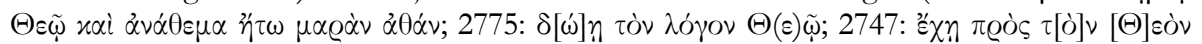

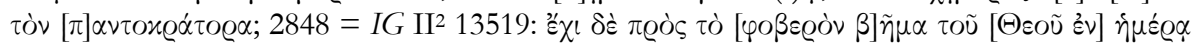

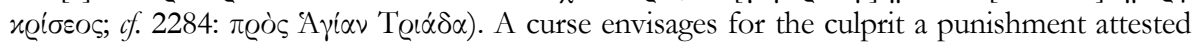

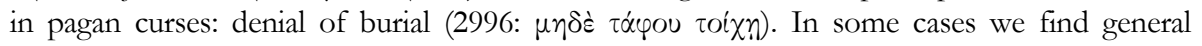

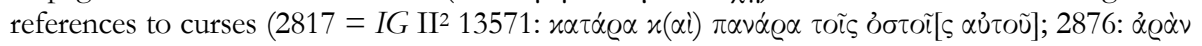

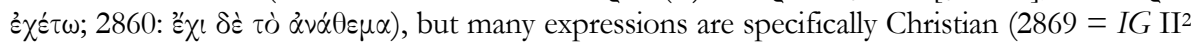




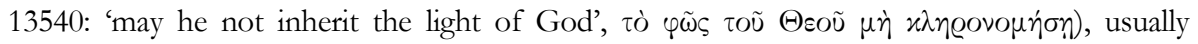
referring to Judas and to the crucifixion $\left(2681=I G \mathrm{II}^{2}\right.$ 13523: 'he shall have Judas' lot and everything shall be darkness for him and God shall destroy him on that day', e' $\chi$ l $\tau \dot{\eta} \nu \mu \varepsilon Q i \delta \alpha \nu$

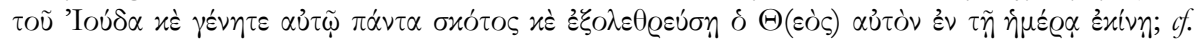

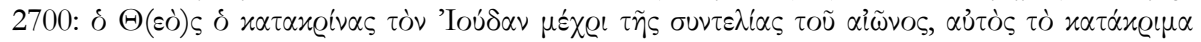

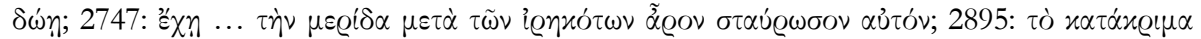

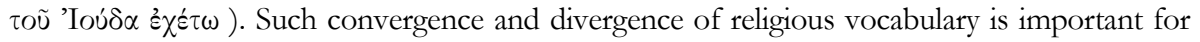
the study of the shaping of religious identities in Late Antiquity.

14) A. Bernabé, "Some Thoughts about the 'New' Gold Tablet from Pherai", ZPE 166 (2008), p. 53-58 [BE 2009, 60]: B. presents a new critical edition of the 'Orphic' tablet from

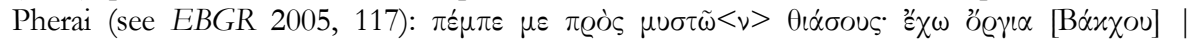

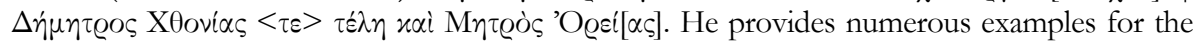

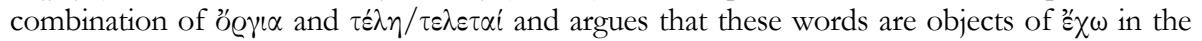
double sense of 'I know/I possess'. He prefers the restoration B $\alpha x \chi O u$, presenting strong arguments for placing this tablet in an Orphic context: the presence of Orphics in Pherai; the use of a gold tablet; the fact that deceased person addresses Persephone (line 1: $\pi \dot{\varepsilon} \mu \pi \varepsilon \mu \varepsilon$ ); the reference to Ai $i \sigma o l$; the association of Orpheus with both Demeter Chthonia and Meter Oreia. The new text adopts the performative schema of many similar tablets: the deceased individual

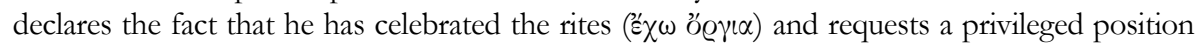
in the underworld.

15) A. BERnABÉ - A.I. JIMÉNEZ SAN CRISTOBAL, Instructions for the Netherworld. The Orphic Gold Tablets, Leiden, 2008 [BE 2009, 62]: Corpus of the known Dionysia-Orphic tablets with a critical edition, translation, commentary, and general discussion of their content and religious context, i.e. Orphic ideas and their diffusion.

16) G. BEVILACQUA - F. FERRANDINI TROISI, "Due amuleti funerari dalla necropoli occidentale di Egnazia", $A S A A 85$ (2007), p. 249-261: Ed. pr. of two gold laminae with amulets found in two separate graves in Egnazia (Apulia, 4th cent. CE). The texts consist of Egyptian magical words and names of Egyptian gods ('il nome grande plethi Moui Sro Pan Ra il grande, re degli

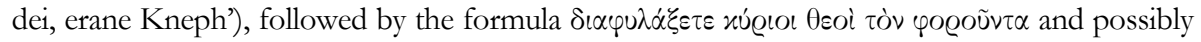
the phrase $\dot{\delta} \mu \tilde{\omega} \nu \tau \dot{\alpha} \delta \dot{v} \delta \dot{\mu} \tau \alpha$. The two texts provide evidence for the diffusion of magical practices, with Egyptian connections, in Apulia.

17) I. BîRZESKU, “Zu den ältesten Steininschriften aus Istros”, Dacia 51 (2007), p. 133-137 [BE 2008, 376]: B. presents revised texts of the earliest dedications from Histria, a dedication by Telon and a dedication to Apollon (I.Histriae 102-103, c. 550-500).

18) J.-F. BOMmelaer, "À nouveau les comptes de Delphes et la reconstruction du temple d'Apollon au IVe siècle av. J.-C.”, BCH 132 (2008), p. 221-255: B. studies the Delphic accounts cooncerning technical and financial aspects of the reconstruction of the temple of Apollon at Delphi in the 4th cent.

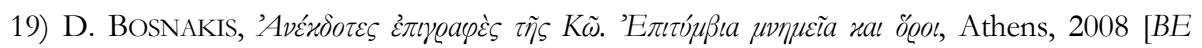
2009, 402-403]: Ed. pr. of 308 epitaphs from Kos [for another large collection of Koan epitaphs see EBGR 2007, 132]. A large number of the new texts are boundary stones of the

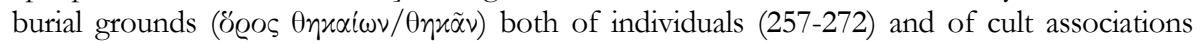
(273-287), typical for Kos (c. 3rd cent. BCE-2nd cent. CE). Usually, the name of the associations ( $\theta i \alpha \sigma o \zeta, \theta \imath \alpha \sigma i \tau \alpha l)$ consists of names deriving from the name of a deity (e.g. Agathodaimonistai) followed by the name of the chairperson (oi oiv + name); in one case the

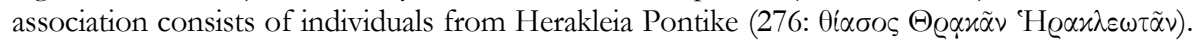
The thiasoi attested in this collection of texts were dedicated to the worship of Agathos 
Daimon (277-279), Aphrodite (280-281), Homonoia (283-285), Nike (282), and Osiris (286), Poseidon (287). In the case of the thiasos of the Aphrodisiasts, the association was chaired by a woman (280-281). From among the other epitaphs, we single out a grave designated as

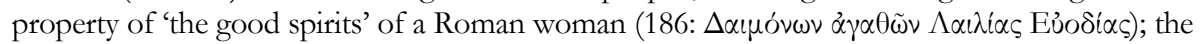

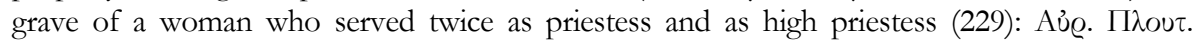

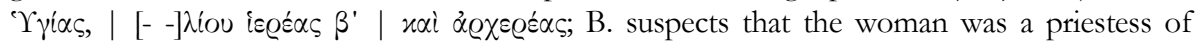
Helios and wonders whether ' $\Upsilon \gamma$ í $\alpha$ is a personal name or the name of the goddess. [Should we

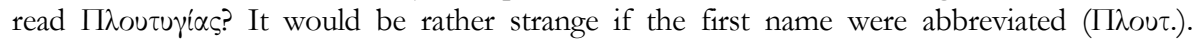
Theophoric names composed of the names of two deities (in this case Ploutos and Hygieia) are not uncommon (e.g. Serapammon).] A man had the personal name Hieratikos (177).

20) D. Bosnakis - K. Hallof, “Alte und neue Inschriften aus Kos II”, Chiron 38 (2008), p. 205-242 [BE 2009, 404]: B.-H. publish or republish inscriptions from Kos. A dossier of letters of Emperor Claudius (25-29), in which his physician C. Stertinius Xenophon is referenced, may be part of a collection of documents concerning this prominent Koan. In the first letter $(25,47 / 48 \mathrm{CE})$ the emperor refers to an embassy from Kos that brought him a decree and informed him about celebrations in his honour either after the supression of a conspiracy or after his return from Britain: 'through what is written in the decree) I recognize the continuous positive attitude that you have towards me not only from the fact that you have

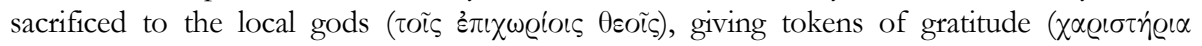
$\dot{\alpha} \pi \circ \delta i \delta o v \tau \varepsilon \varsigma)$ for our rescue, both as a community and privately, dressing in white garments

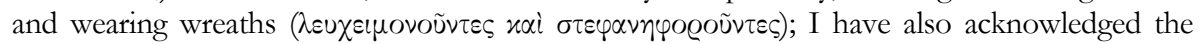
fact that after the contest for the gods you performed for me the most sublime celebrations for

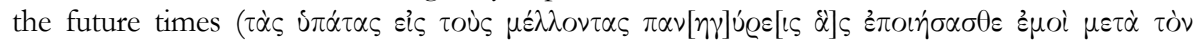
$\dot{\alpha} \gamma \tilde{\omega} \nu \alpha \tau \tilde{\omega} \nu \theta \varepsilon \tilde{\omega} \nu)$, praising the unshaken preservation of our rule, in a manner worthy of the already existing privileges that I grant the people for ever, finding new benefactions for the common good for all the cities that perform sacred celebrations for us ( $\tau \dot{\alpha} \varsigma \varepsilon[\dot{0}] \varepsilon \varrho \gamma \varepsilon \sigma i \alpha \varsigma$

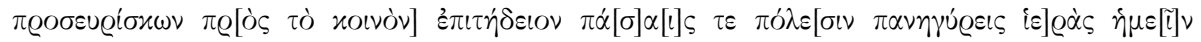

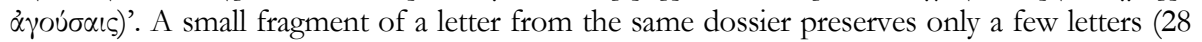
= Iscr. Cos ED 125); the text refers to the freedom of Kos and to the 'sanctuary of the god' (sc. the Asklepieion). Among the other inscriptions we mention an inscription commemorating a gladiatorial event, during which 23 gladiators were killed and one was pardoned (30, 1st cent.

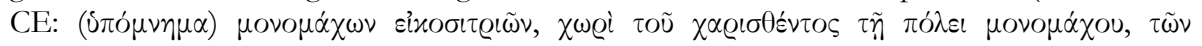

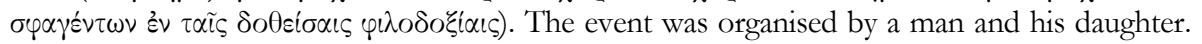
No office is mentioned, and this is in accordance with the fact that in the early Imperial period gladiatorial combats were organised by private individuals. An honorary inscription was set up for a pious woman who occupied numerous priesthoods (32 = Iscr.Cos EV 226, c. 14-37 CE):

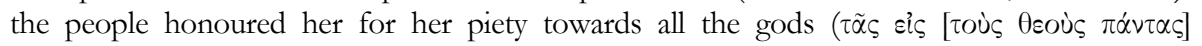

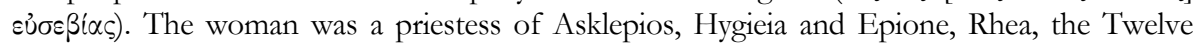
Gods, Zeus Polieus, Athena Polias, and Tiberius, as well as former priestess of Apollon Delios and Apollon Karneios [on Apollon Delios and Artemis Delia see EBGR 2006, 54]. A fragmentary honorary inscription lists among the services offered by the anonymous benefactor the restoration of buildings, possibly after the earthquake of $47 \mathrm{CE}$ (33). The earthquake had damaged the quadriga of Victory and the Emperor and other statues near the sanctuary of Asklepios; the text also refers to the asylia of Kos and the temple of the Augusti. A fragmentary document records an endowment ( $\alpha v \varepsilon$ $\varrho \omega \sigma \iota \varsigma)$ made by Euphrosynos (35, 3rd cent. CE). The money was to be spent for the performance of rosalia on the graves of certain

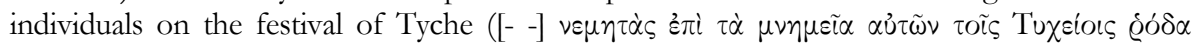

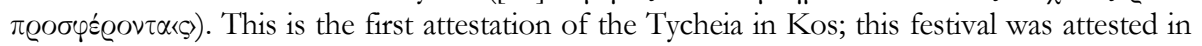
Lampsakos (I.Lampsakos 13). 
21) C. Brélaz - A. Andreiomenou - P. Ducrey, "Les premiers comptes du sanctuaire d'Apolon à Délion et les concours pan-béotien des Delia", BCH 131 (2007) [2009], p. 235-308: Ed. pr. of the first part of an important epigraphic dossier from Dilesi (ancient Delion, on the territory of Tanagra). The dossier consists of three financial documents: the accounts of the agonothetes (a man from Orchomenos) of the Pamboiotian contest of the Delia during the archonship of Theochares (I); undetermined accounts of the same year (II); and a summary of the interest paid by the polemarchoi in a period of 5 years (III). The accounts of the agonothetes list

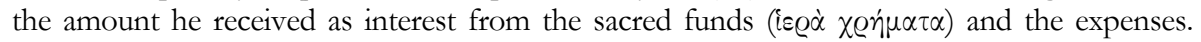
These expenses give us an excellent insight into costs in connection with festivals and contests. Money was spent for a sacrifice to Apollon on the occasion of the procession of the theoroi, followed by a banquet; for a sacrifice during the oath ceremony for the artists, the athletes, and the theoroi; for laurel wreaths, bands, lamps, and torches; for the gilding of crowns; for the

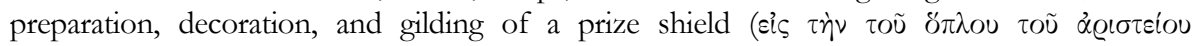
$\pi \alpha \varrho \alpha \sigma \varkappa \varepsilon \cup \eta \dot{v} \nu$; for the asylia of the theoroi, the officials, and the other individuals, to whom the

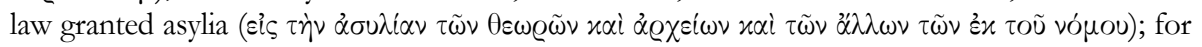
the assistant scribe; for the servants (i்n@é $\tau \alpha$ ); for cleaning the shields used in the race of

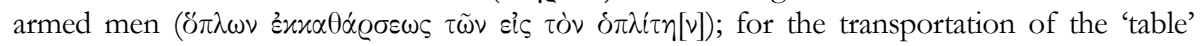

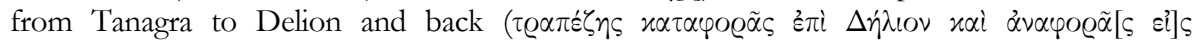

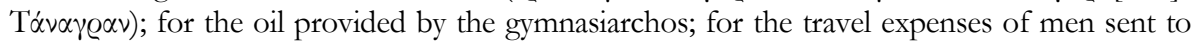
Thebes and Athens to purchase weapons. The text concludes with a short, fragmentary report of the agonothetes, stating that he had provided the crown for the victor in a race of men (stadion?) at his own expense, and that he handed over money (?) to his successor, who had already been elected, and to other men.

22) A.M. Butyagin - A.P. BeKHTER, "Novye nadpisi iz Mirmekija", in Eucharisterion, p. 7281: Ed. pr. of a dedication made to Demeter Thesmophoros by a woman after a prayer

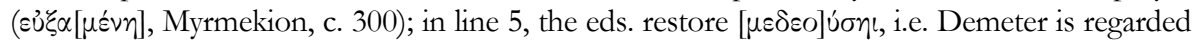
as a ruler of this site.

23) S.G. BYRne, "The Dedication of the Orgeones of Prospalta $I G \mathrm{II}^{2} 2355$ ", in Mikros Hieromnemon, p. 117-132: B. discusses a dedication to Asklepios by the orgeones of the deme of

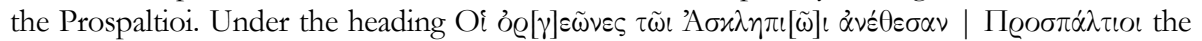
names of 16 men are listed in two columns. As one may infer from the names and patronym-

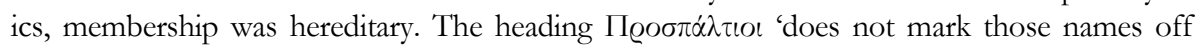
from others of different demes. ... The rubric Пழoб $\pi \dot{\alpha} \lambda \tau \iota$ is used ... to give a label to these particular orgeones, as if to declare that this is the Prospaltian association of orgeones' ( $f$. IG II 2967). Because of the form $\alpha v \varepsilon \varepsilon \varepsilon \varepsilon \sigma \alpha \nu$, instead of $\alpha v^{2} \theta \eta \eta \alpha \nu, B$. dates this text to the 4th cent. He argues that IG VII 33 ([oi $]<\delta>\varepsilon \delta \varrho \gamma \varepsilon \tilde{\omega}<\nu>\varepsilon \varsigma<\tau>\tilde{\omega} \nu \theta \varepsilon \tilde{\omega} \nu$ ), found in Megara, is a similar dedication of orgeones, probably from Eleusis.

24) J.-D. CAhn AG, Basel, Auktion 5. Kunstwerke der Antike, 23. September 2005, Basel, 2005 [SEG LVI 2047]: One of the objects offered for sale is a statuary group representing two women (unknown provenance). An inscription on the base (read by R. TYBOUT in SEG) mentions that these statues were dedicated by a sculptor 'in accordance with the command of

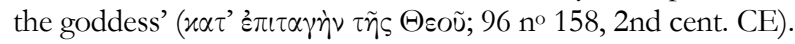

25) M.L. CALDELLI, "Virgilio, Eneide V: I giochi funebri e le realtà sportive”, in G. PACI (ed.), Contributi all'epigrafia d'età Augustea. Actes de la XIII rencontre franco-italienne sur l'épigraphie du monde romain, Macerata, 9-11 settembre 2005, Tivoli/Rome, 2007, p. 91-114: C. places Vergil's description of the funeral contests for Anchises (Aen. V) in the context of the Augustean agonistic culture, focusing in particular on the literary and epigraphic evidence for the Aktia of Nikopolis. 


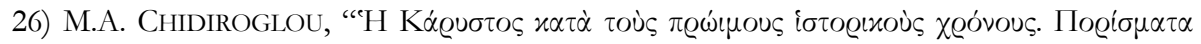

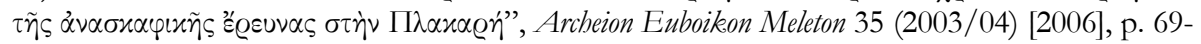
80 [BE 2007, 325; SEG LVI 1037]: C. presents a fragmentary cult regulation copied by D. Keller at Plakari (area of Karystos, Euboia, 4th cent.). [D. KNOEPFLER, BE 2007, 325,

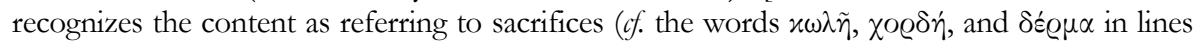
3-6). As I noted in SEG LVI 1037, the text refers to the part of the victim that was given to the priest. One recognizes forms of $\mu$ é@oৎ or $\mu \varepsilon \varrho i \varsigma$ (line 1) and $\delta i \delta \omega \mu$ (line 2), followed by

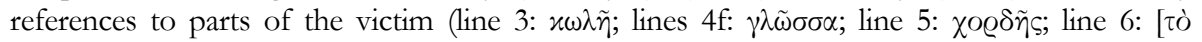

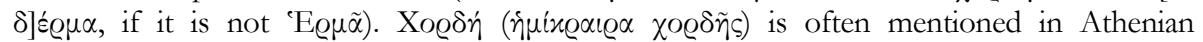

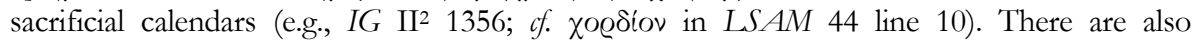

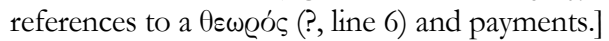

27) CHristie's, London, Antiquities, Wednesday 25 October 2006, London, 2006 [SEG LVI 2044]: We present two inscribed objects offered for sale; the readings are by R.A. TYBOUT (SEG).

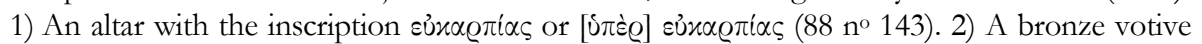
hand with a four-line Greek inscription incised on the palm (89 no 144, 1st/2nd cent.). 3) A

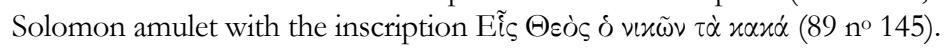

28) CHRIsTIE's, New York, Antiquities, Thursday 7 December 2006, New York, 2006 [SEG LVI 2039, 2058]: The items offered for sale include the following inscribed objects of unknown provenance, mostly amulets. The texts were read by R. TYвout (SEG): 1) An inscribed bronze helmet dedicated in a sanctuary (i $\propto \varrho 0[--]$, c. 550-500, p. 72 no 76). 2) A Chnoubis-

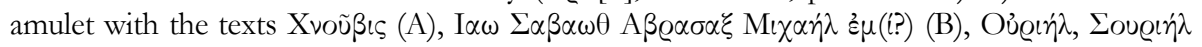
(C; $\left.58 \mathrm{n}^{\circ} 313\right) ; 3$ ) Amulet with AI $\Omega$ and a sequence of vowels (59 no 315). 4) Amulet with the rider Solomon and the text $\Sigma o \lambda o \mu \omega \dot{v}$ and $\sigma \varphi \varrho \alpha \gamma i \varsigma$ $\theta \varepsilon o \tilde{u}$ SSS (59 no 314).

29) K. CuInton, Eleusis. The Inscriptions on Stone. Documents of the Sanctuary of the Two Goddesses and Public Documents of the Deme. Volume II. Commentary, Athens, 2008 [BE 2009, 224]: After a short but very useful introduction to the sanctuary of Demeter and Kore at Eleusis, its administration, the mystery cult, the sacred officials, festivals (Lesser Mysteries, Eleusinia, Proerosia, Haloa, Chloia, Kalamaia), the deme festivals (Dionysia, Thesmophoria, festival of Herakles in Akris), and the imperial cult, C. discusses in detail the texts contained in the first volume (see EBGR 2005, 39) [cf. the remarks of S. FOLLET, BE 2009, 224].

30) K. Clinton, "Preliminary Initiation in the Eleusinian Mysteries", in Mikros Hieromnemon, p. 25-34: Inscribed boundary stones in the sanctuary of the Great Gods in Samothrace

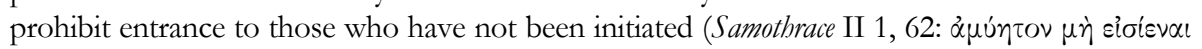
घic tò i̊góv). But since in order to get initiated, one had to enter the sanctuary, the term

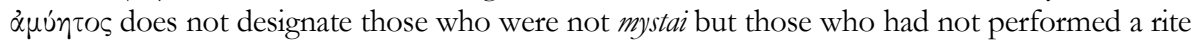
that qualified them for initiation. This 'preliminary initiation' ( $\mu$ únoıৎ) is indirectly attested for the Eleusinian Mysteries. The pilgrims underwent this rite either in the court of the sanctuary of Eleusis or in the Eleusinion below the Acropolis ( $c f$. IG I3 $6=$ I.Eleusis 19 C 20-31 and 4346). The public slaves who cleaned the sanctuary in Eleusis and the men who transported stone from Pentele to the sanctuary had to undergo this myesis in order to be able to enter the sanctuary (I.Eleusis 159 lines 24 and 62; ff. I.Eleusis 177 for myesis of public slaves c. two weeks before the Lesser Mysteries). The rite was carried out by the Eumolpidai or the Kerykes

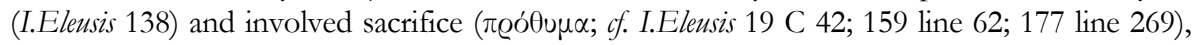
and probably purification, instruction, and the closing of the initiate's eyes, thus providing a foretaste of the experience during the Mysteries. It took place a few weeks before the Greater and Lesser Mysteries. 
31) J. Crouwel et al., "Geraki, an Acropolis Site in Lakonia. Preliminary Report on the 11th Season (2005)", Pharos 13 (2005), p. 3-28 [BE 2007, 32]: C. mentions a stamped tile that refers to Apollon and the inhabitants of Geronthrai (Geronthrai in Lakonia, Hellenistic, p. 14f.). According to C. this tile was from the sanctuary of Apollo (cf. Paus., III, 2, 6-7) [but M. SĖVE, $B E 2007,32$, observes that the letters in line $1([--] \lambda \lambda \omega v[--])$ may be part of a theophoric name; see also infra no 32].

32) J. Crouwel-M. Prent-D.G.J. Shipley, "Geraki, an Acropolis Site in Lakonia. Preliminary Report on the 13th Season (2007)", Pharos 15 (2007), p. 1-16: S. restores the text on a tile found at Geraki (Lakonia) as [Aлó] $\lambda \lambda \omega \nu[o \varsigma] \mid[\Gamma \varepsilon \varrho o] \nu \theta \varrho \alpha ́[\tau \alpha]$ (p. 11-13). This cult epithet is unattested.

33) K.F. DALY, “Two Inscriptions from the Athenian Agora, I 7571 and I 7579”, Hesperia 76 (2007), p. 545-554 [BE 2008, 199]: Ed. pr. of a list of prytaneis from Athens (191/2 CE). The recipients of free meals (aisitor) in the list include, as is common in this period, Eleusinian

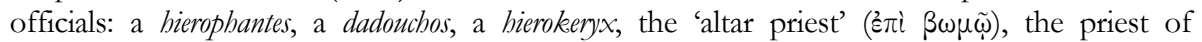
Phosphoroi, and a certain Aurelius (probably Aur. Alkamenes), who is characterized as

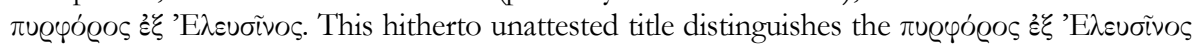

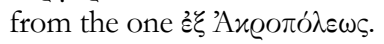

34) A. Dimartino, "Per una revisione dei documenti epigrafici siracusani pertinenti al regno di Ierone II", in C. MiCHELINI (ed.), Guerra e pace in Sicilia e nel Mediterraneo antico (VIII-III sec. a.C.), Pisa, 2006, p. 703-717 [SEG LVI 562, 1103]: D. assembles inscriptions concerning the rule of Hieron II of Syracuse (270-215 BCE). They include the following dedications: of the Syracusans to all the gods (IG XIV 2); of the Tauromenians to Zeus Olympios in Olympia (ISE I 58); of the Syracusans to Zeus Hellanios (Syll.3 428); of Nereis and Gelon to Apollon in Delphi and Zeus in Olympia in honor of the Epeirotan royal house (F.Delphes III.4.235; I O 310); and of a Syracusan king to Demeter and Kore (SEG XXXIV 979).

35) S. DAR - N. KOKKINOS, "The Greek Inscriptions from Senaim on Mount Hermon", Palestine Exploration Quarterly 124 (1992), p. 9-25 [SEG XLII 1408-416]: Ed. pr. of 9 altars from the sanctuary of Senaim, on Mount Hermon, near Caesarea Panias (2nd/3rd cent.) [republished with improvements by J. ALIQUOT, supra no 5 A2-10; we incorporate his remarks in this lemma]. The identity of the god or gods cannot be determined (Zeus, Helios, Sarapis?). An inscription on a limestone altar records that it was dedicated by three men when another

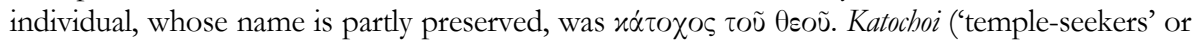
'temple-recluses under a vow') are known to have commissioned and supervised dedications in Syria [ALIQUOT (A2) observes that the katochoi are attested as a separate group than the priests. They were usually wealthy devotees responsible for construction work in sanctuaries. He favours the interpretation of the term katochos as 'one possessed by a god' ('qui est maintenu, possédé')]. A man who served as é $\pi i \tau^{\alpha} \alpha^{\prime \prime} x \tau[\alpha]$ (actuarius militariensis?) made a dedication for the salvation and victory of the emperors M. Aurelius and L. Verus (2) [P.-L. GATIER, BE 1993, 629 , tentatively suggest reading 'A $\propto \tau[\llcorner\alpha]$ (i.e. the local agonistic festival Aktia. This is rejected by ALIQUOT (A3)]. Other dedications were made upon prayer (3: $\varepsilon \dot{\jmath} \xi \dot{\alpha} \mu \varepsilon v o \varsigma)$ or in fulfilment of a

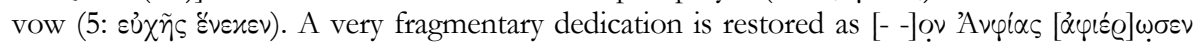

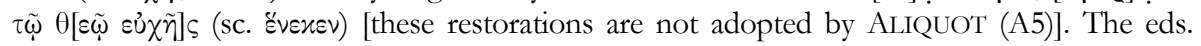
tentatively interpret the text $\mathrm{I} \Delta \mathrm{I} \Delta \mathrm{EO}(8)$ as a dedication to Zeus Idaios ( $\Delta i$ 'I $\left.I \alpha \alpha^{i} \omega\right)$ [this is rejected by ALIQUOT (A9)].

36) F. Daubner, "Der pergamenische Monat Eumeneios", EA 41 (2008), p. 174-180 [BE 2009, 419]: D. argues that the month Eumeneios (IvPergamon 249) does not derive from a king Eumenes, but more probably from Zeus Eumenes. 
37) J.-C. Decourt - A. Tziafalias, "Mythological and Heroic Names in the Onomastics of Atrax (Thessaly)", in E. MATTHEws (ed.), Old and New Worlds in Greek Onomastics, Oxford, 2007, p. 9-20: After presenting an overview of the c. 600 names attested in Atrax in Thessaly, D.-T. briefly mention the theophoric names and focus on names inspired by myths and heroes (rivers: e.g. Peineiodouros; heroes: e.g. Phorbas, Kaineus, Hoplon, Protesilaos, Neoptolemos, Phoinix etc.).

38) N.M. Dimitrova, Theoroi and Initiates in Samothrace. The Epigraphic Evidence, Princeton, 2008: D. presents a thorough study for the evidence of theoroi in Samothrace, including an introduction to the etymology and function of theoroi and the epigraphic evidence for theoroi in general and in Samothrace in particular (p. 9-20). The main part of the book is a corpus of attestations of theoroi (p. 21-74 nos 1-20, 22-25; nos 14-17 and 19 list both theoroi and initiates) and initiates (p. 77-238) in Samothrace. Theoroi: Four of the inscriptions mentioning theoroi are dedications: by theoroi of Patara (21) and Paros (27-28) and by the Thessalian Koinon (26). There are a few inedita. No 11 attests theoroi from Kos, Bargylia, Klazomenai, and the association of Dionysiac artists [of Ionia and Hellespont? (cf. no 10)]. The theoroi mostly came from Thrace, the Aegean islands, and Asia Minor; on the contrary there are only rare attestations of theoroi from Thessaly, Athens, and the Peloponnese. Mystai: The epigraphic evidence for initiates (nos 29-167) is arranged according to their origins. D. discusses the information provided by these texts for the provenance of the initiates (Athens, the Peloponnese, Thessaly, Illyria, Macedonia, Thrace, the Aegean Islands, the west and north Shore of the Black Sea, Sicily and Rome, Asia Minor, Syria, and Egypt); the status of the initiates (mostly men, some women, many slaves and freedmen); the stages of initiation; the existence of an annual festival (no 103; p. 243-249). The evidence consists of records of mystai (30-146) and an epitaph (29). Among the inedita we note no 31 which records initiates from Alexandria (the first attestation of an initiate from this city), Tegea, Thera, Torone, and Aspendos, and no 46 commemorates the initiation of Rhaskos, the son of the Thracian king C. Iulius Rhoimetalkes II, and Queen Antonia Tryphaina, wife of King Kotys VIII of Thrace (c. 40-45 CE), in addition to mystai from Abydos, Odessos, and unknown origin as well as several freedmen. Some of the texts provide information about the context of initiation. One of the initiates from Tralleis was responsible for the announcement of the Pytbia of Tralleis

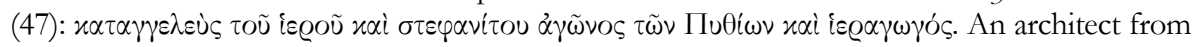
Kyzikos was initiated when the Kyzikenes sent him to Samothrace for some construction

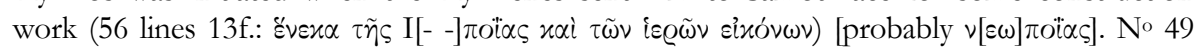
commemorates the initiation of the crew of two ships that had fought against pirates; it also contains an honorary decree for foreign judges; judges are also recorded as initiates in no 62 . Also Roman military personnel was initiated in Samothrace (57). A fragmentary text refers to a historiographos (126, ineditum). In appendices, D. republishes other relevant inscriptions concerning initiates (p. 239-242, 257f.) and theoroi (251-255). These texts include: prohibitions preventing uninitiated individuals from entering the sanctuary $(168=$ LSCG Suppl. 75; $169=$ LSCG Suppl. 75a); an honorary decree for a Ptolemaic governor of Hellespont and Thrace (170); a decree of Odessos concerning the mysteries of Samothrace (171 = IGBulg I $\left.{ }^{2} 42\right)$; a Koan decree mentioning theoroi sent to Samothrace (p. 251 no 1); honorary decrees of Samothrace for a Koan proxenos (p. 251f. no 2), theoroi from Iasos (p. $253 \mathrm{n}^{\circ}$ 3), and poets, who performed in Samothrace (253f. nos 4-5); and inscriptions from Rhodes, Tomis, and Dionysopolis referring to initiates (257f.).

39) N. Dimitrova, "Priestly Prerogatives and biera moira", in Mikros Hieromnemon, p. 251-257

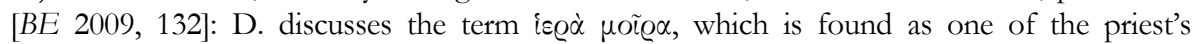
prerogatives in cult regulations ( $L S A M 48,52 \mathrm{~b})$ and sales of priesthoods ( $L S A M 40,44,63)$ in 


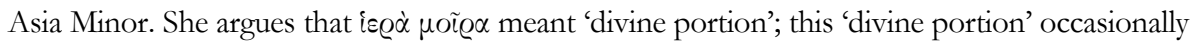
functioned as a priestly perquisite. It denoted the tail or lower back of the victim.

40) L. Dubois, Inscriptions grecques dialectales de Sicile. Tome II, Geneva, 2008 [BE 2009, 559]: Corpus of the dialect inscriptions of the colonies of Euboia (Katane, Leontinoi, Naxos, Stielana), Megara (Selinous), Corinth (Syracuse, Kamarina), Rhodes (Akragas, Gela), as well as the cities in west (Motye, Lilybaion, Iattas, Entella, Segesta, Mytistratos, Sichana, Sipana), and central Sicily (Troina/Engyon, Echetla, Palagonia, Centuripe, Morgantina, Adrano). Most of these texts were also included in R. ARENA's collections summarized in EBGR 1989, 6 and 1993/94, 10. Naxos: A dedication to Enyo (2, late 7th cent.). Leontinoi: A dedication to the Dioskouroi (11, 5th cent.). A vase was donated on the occasion of a funerary banquet $(10,5$ th

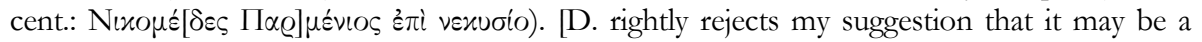
reference to the month Nekysios (EBGR 1996, 232), since this month is not attested in Sicily and month names are not introduced with epi. Since the inscription is written on the rim of a vase, in a circle, it is not clear where it starts. The personal name may be in the genitive: $\varepsilon \pi i$

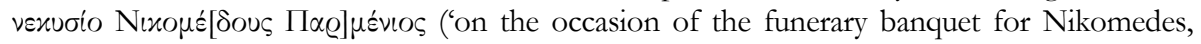
son of Parmenes').] Katane: Dedications to Demeter and Kore (14, c. 300; by a man and his family), Herakles (17.2), and Leukathea (17.2). Selinous: For the well-known regulation concerning purification (18) see EBGR 2004, 74; D. presents a line-by-line commentary. The other texts are curse tablets (26-38), for which see EBGR 2004, 151 and 2005, 16 and 99. Kamarina: Legal documents are dated through reference to the eponymous theokolos (52, 53). A

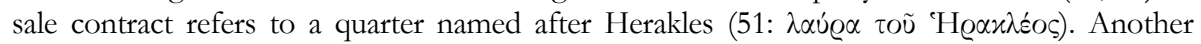
contract concerning the sale of vineyards and the adjacent land excludes some sacred objects

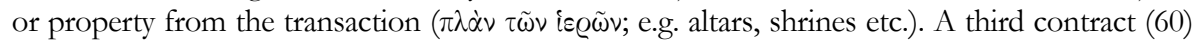
mentions a small temple (vaïoıov) near a potter's workshop. Three curse tablets (61-63, 5th-3rd

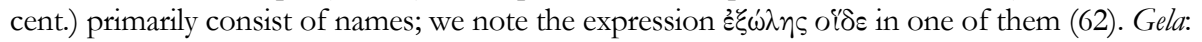
A strigilis was intended as a prize in a contest (74, c. 400: $\tilde{\alpha} \theta \lambda \circ v)$. Akragas: The most interesting

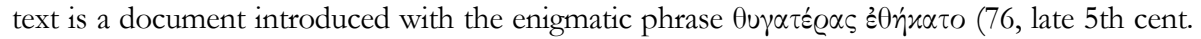
BCE). This was originally interpreted as a dedication of three girls (EBGR 2004, 180) and is now interpreted as an adoption document (EBGR 2005, 107 and A.V. WALSER,

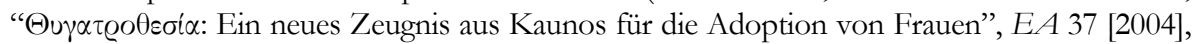
p. 101-106) [but $c f$. my objections in EBGR 2005, 107: the adoption of women was practiced for specific reasons, usually in order to make sure that certain privileges (e.g. priesthoods) remain in a family; one adopts one girl, not three at the same time. In a legal document concerning the adoption of (free) women one expects that their father's name is given]. A

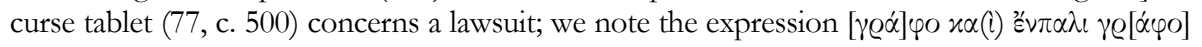
('je les inscris (dans le plomb) et c'est à l'envers que je les inscris'). The nature of a lead tablet with the expression $\pi \alpha \varrho x \alpha \tau i \theta \varepsilon \tau \alpha \iota$... $\pi \dot{\alpha} \varrho \tau \tilde{\omega} \iota$ h $\eta \varrho \alpha \lambda \lambda \varepsilon \tilde{\imath}$ (78, Palma di Montechiaro, 4th cent.) is not certain: curse tablet, manumission record, or deposition of money? Libybaion: For a curse tablet (80) see EBGR 1998, 135. Segesta: A reference to an eponymous hieromnemon (89, c. 250). Mytistratos: Two dedications to anonymous deities (91, 5th cent.). Adrano: A vase was dedicated

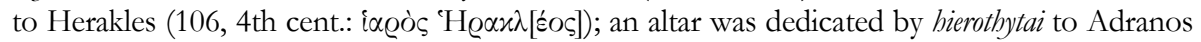
(107, c. 200). Agyrion (area of): Sale contracts are dated with reference to an eponymous priest (110-111, 3rd cent.). Aetna-Inessa: A dedication of unknown date was made by a bronze-smith

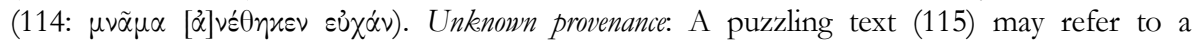
dedication (АПАРХHN $=\alpha \pi \alpha \varrho \chi \eta ் ?$ ?). An inscribed lead tablet seems to be a curse tablet, but

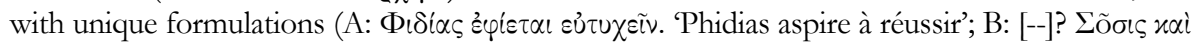

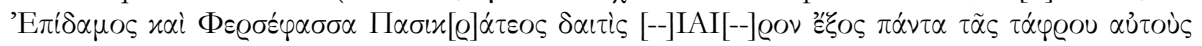

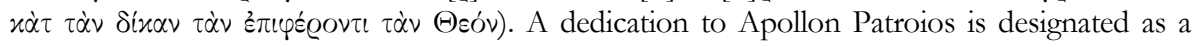
tithe (dekata; 121, 5th cent.) [it is not accurate that 'la consécration d'une dîme ne semble pas 


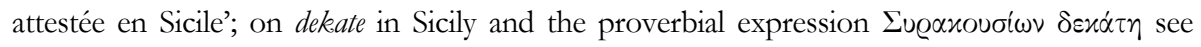
EBGR 2005, 130].

41) N. EHRHARDT, "Der Bürger als Heros: Staatsbegräbnis und Öffentlichkeit in Kyzikos", in Festschrift Schwertheim I, p. 187-196: E. discusses the decree of Kyzikos concerning the funeral of Apollonis (SEG XXVIII 953, c. 25-50 CE) and places it in the context of the attribution of heroic honours to benefactors in the Hellenistic and Imperial period. He discusses in particular the measures taken by this and similar decrees in order to increase public participation in the funeral and the commmoration of the benefactor (closing of temples, attendance of the funerary procession, burial within the city walls, erection of statues, annual commmorative rites).

42) G. Ekroth, "Meat, Man, and God. On the Division of the Animal Victim at Greek Sacrifice", in Mikros Hieromnemon, p. 259-290: Drawing on inscriptions (cult regulations) and iconography, E. studies the practicalities of how the meat of the sacrificial animal was divided and distributed (butchering, choice portions and their recipients, equal portions, the timing and location of the meat's distribution, and the place of the meat's consumption).

43) F. ERTUĞRUL, "Some New Inscriptions from Tralleis and Aphrodisias", EA 41 (2008), p. 87-90 [BE 2009, 441]. Ed. pr. of 5 inscriptions. Tralleis. The people honour a priest of Dionysos Bakchios (1, late Hellenistic/early Imperial period). The cult of Dionysos Bakchios was already attested in Tralleis (I.Tralleis 3). A building inscription commemorates the Asiarch Kydoros, otherwise unattested; he donated a building as summa honoraria for the office of the stephanephoros (2, Imperial period). Aphrodisias: Two statuettes representing an eagle were dedicated to Zeus by Adrastos (4) and Meltine (5) in fulfilment of their vows. [For a similar statuette dedicated to Zeus Nineudios see SEG LIV 1037 = EBGR 2004, 43; the two new statuettes were probably also dedicated to Zeus Nineudios. Meltine must be the same woman as a certain Melitine, who made another dedication to Zeus Nineudios on behalf of her son

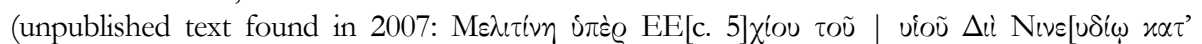

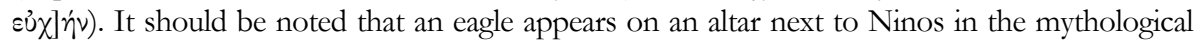
reliefs of the civic basilica at Aphrodisias. Local mythographers associated Ninos with the early name of Aphrodisias, Ninoe, which in its turn is connected with the epithet of Zeus Nineudios.]

44) R. Étienne - F. Prost, “Claros, les modèles delphiques au pays des Létoïdes”, Arkeoloji Dergisi 12 (2008.2), p. 75-87: The authors discuss the development of the cult and the oracular practices in Klaros and the shaping of a local cultic profile in the context of Greek religion and as a response to the cult of Apollon in other sanctuaries. They briefly discuss the activity of Timonax (mid-sixth century), probably the first priest of the sanctuary (p. 83f.). They argue that the cult of Apollon presents a synthesis of different Apollonian traditions referring to the myths of his birth and his functions as an oracular god and as a patron of music. There is no evidence for oracular activity earlier than the Hellenistic period. In this context, they briefly present two unpublished inscriptions: a record of the visit of hymnodoi from Hadrianopoulis (p. 81 note 33) and an important decree of the Ionian Koinon concerning the re-organisation of the festival of the Klaria and the participation of the Ionians (3rd cent.). The decree refers to the problems caused for the pentaeteric Klaria by the wars and to Apollon's wish to see his

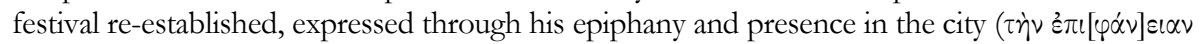

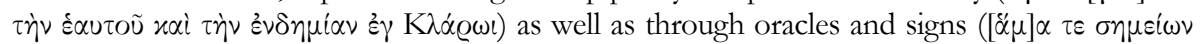

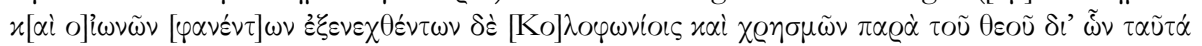

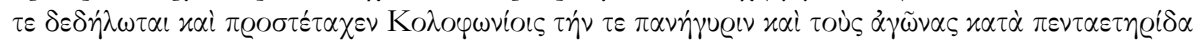

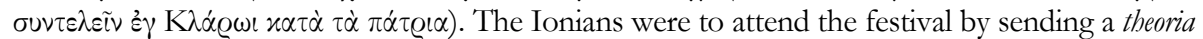
every four years and participating in the customary sacrifice to Apollon Klarios and Artemis Klaria [on the development of the cult in Klaros see also infra no 47 ]. 
45) E. FABricotTi, “Arulette di Cirene”, in Cirene e la Cirenaica, p. 267-302 [BE 2008, 601]: F. presents small altars from Kyrene (Imperial period), among them altars dedicated to Sarapis and Isis (7), Demeter and Kore (8), and Iatros and Iaso (9).

46) M. FACELLA - E. WINTER, "Neue Inschriften für Iuppiter Dolichenus aus dem östlichen Mittelmeerraum", Festschrift Schwertheim I, p. 217-228: Ed. pr. of one Greek and two Latin dedications to Iupiter Dolichenus. The fragmentary Greek text (1, from Dülük Baba Tepesi near Doliche) is a dedication to Theos Epekoos Dolichenos by a group of individuals after a prayer ( $\varepsilon \dot{\jmath} \xi \dot{\alpha} \mu \varepsilon v o \imath)$. A Latin text from the same site is addressed to Iupiter Optimus Maximus in fulfilment of a vow. The second Latin text (to Iupiter Optimus Maximus Dolichenus), from Zela, is a dedication pro salute of an emperor.

47) J.-L. Ferrary, "Les apports du dossier des mémoriaux de délégations de Claros dans les Fonds Louis Robert", CRAI (2008), p. 1377-1404: F. surveys the inscriptions that commemorate the visits of delegations of foreign cities to the sanctuary of Apollon in Klaros (c. 105-35 $\mathrm{CE}$ ) and gives an overview of their contribution to the study of the cult. The inscriptions mention the names of the main cult officials: the priest of Apollon and the thespiodos (both serving for life), the annual prophet and his secretaries. The thespiodos is attested for the first time around $130 \mathrm{CE}$ and from $181 \mathrm{CE}$ he is mentioned before the priest; in the two last records, the thespiodos for life Ti. Iulius Nereus changes his title and uses the title bypophetes. It seems that the thespiodos, who served for life was the true successor of the original bypophetes, who came from Smyrna in the Hellenistic period, when the oracular practice started; on the contrary, the prophetes was selected on an annual basis from among the elite families and his prestige was based on social position, not divinatory inspiration. F. suspects that the position of the thespiodos was upgraded under Hadrian or Antoninus Pius and finally assumed the old title of the hypophetes. The delegations came from cities in Asia Minor (especially recent foundations and cities in areas that were Hellenized in relatively late times) and Crete, and less frequently from Achaia, Macedonia, Thrace, and the east and north coast of the Black Sea. Regular visits are attested especially for Laodikeia on Lykos, Chios, Phokaia, and Herakleia Salbakis. Of course, one has to consider the fact that the epigraphic commemoration of a visit was not obligatory. The participation of choruses of young men (from Akmonia, Amaseia, Aphrodisias, Chios, Herakleia Salbakis, Hierapytna, Ikonion, Laodikeia on Lykos, Lappa, Phokaia, and Tabai) was very important; the singing of hymns must have been requested by the god through an oracle, possibly as an expression of gratitude. The choruses of young men, some of which are designated $\alpha \mu \varphi \imath \theta \alpha \lambda \varepsilon i \varsigma$ है $\varphi \eta \beta o \iota$ or $\dot{\mu} \mu \nu \omega \delta o$, were accompanied by adults (chorus masters, teachers, paidonomoi, supervisors, heralds, choregoi); the visit to the sanctuary and the singing of hymns played an important part in the education of the youth. One of the choregoi from Chios, T. Flavius Stratonikos Megenor, was a descendant of Homer (Homerides). In some cases, the memorials of visits refer to the consultation of the oracle and an initiation

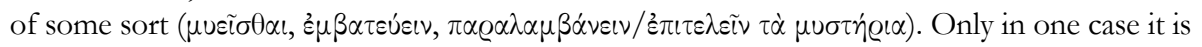
mentioned that a chorus (sent from Lappa on Crete) was also initiated, due to the theopropos'

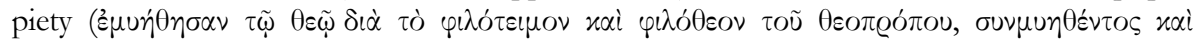
$\alpha \tilde{\tau} \tau O \tilde{u})$. The term $\varepsilon \mu \beta \alpha \tau \varepsilon u ́ \varepsilon \iota \nu$ must denote the entering of the subterranean part of the sanctuary and the performance of rites; these mysteries may be a recent innovation (2nd cent. CE?), possibly the result of competition among sanctuaries. F. discusses also the eras used in the dating formulas and the honorary titles of the cities.

48) S. Follet - D. Peppas-Delmouzou, "Inscriptions du Musée épigraphique", BCH 132 (2008), p. 473-553: The authors present 39 texts, both inedita and published texts in the Epigraphical Museum in Athens, whenever revisions and joints of fragments permit new restorations. A fragmentary decree mentions the priest of Zeus Eleutherios and Homonoia of 
the Hellenes (1, late 1 st cent. BCE/early 1st cent. CE). A bieraules is mentioned in a fragmentary document $\left(7,2\right.$ nd cent. CE). A list of recipients of free meals (10; part of $I G \mathrm{II}^{2}$ 1808) includes a bierophantes (late 2 nd cent. CE). A revised agonistic inscription honors a victor in a chariot race at the Eleusinia (12, 2nd/1st cent.). A list of victories of a herald (14, 2nd cent. CE) is very fragmentary, but one recognizes victories in the agonistic festival Antoneia and in contests in Sparta and in Asia. A victor from Ephesos made a dedication (15, Imperial period). An honorary inscription for Septimios Euodos of Smyrna, a bieroneikes (16, Imperial period), mentions the fact that he was the agonothetes of a pentaeteric contest of boys and of another fifty or sixty sacred contests. A fragmentary building inscription mentions a priest (21, 1st cent. $\mathrm{BCE} / \mathrm{CE}$ ). The authors republish three funerary epigrams. No 35 is the epigram of a foreigner who came to Athens, to the land of pious people, serving as the priest of a goddess, perhaps

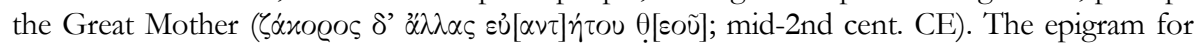

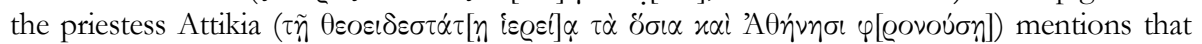
she was buried in the place of her ancestors in Karia; on her cenotaph in Athens she received a

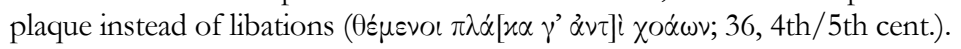

49) J. FOURNiER - P. HAMON, "Les orphelins de guerre de Thasos: un nouveau fragment de la stèle des braves”, BCH 131 (2007) [2009], p. 309-381: After the discovery of a fragment belonging to a Thasian decree concerning public funerals and sacrifices for the Agathoi, the war dead (LSCG Suppl. 64, c. 360-350), the authors publish the entire document. The new fragment shows that this regulation was a decree and not a law and that it dealt also with privileges awarded to their orphans. The Agathoi were honored with a heroic sacrifice (perhaps during the

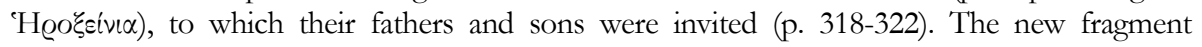
contains regulations concerning the support offered to the orphans of the war dead.

50) J.L. Garcia-Ramon - B. Helly - A. Tziafalias, "Inscriptions inédites de Mopseion",

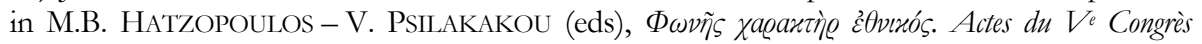
International de dialectologie grecque (Athènes 28-30 septembre 2006), Athens, 2007, p. 63-103: Ed. pr. of 8 dedications and 7 honorary decrees from the Thessalian city of Mopseion. The dedica-

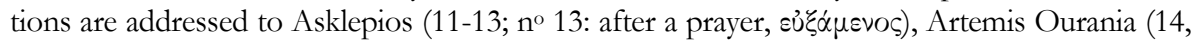

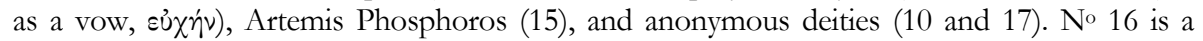

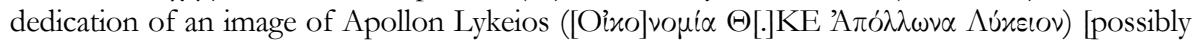
$\theta[\tilde{\eta}] \varkappa \varepsilon$ ('set up')]. The relief shows a female figure with a torch and a phiale (left) and a male figure with a double axe. Two of the citizenship grants (4 and 6$)$ mention that the recipient

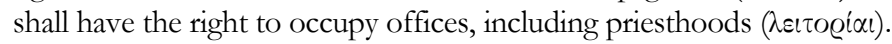

51) S. GIANNOBILE, "Una preghiera cristiana da Reggio Calabria contro l'emicrania, il mal di testa e l'oftalmia”, ZPE 167 (2008), p. 135-143: G. republishes a lead tablet from Reggio Calabria (7th/8th cent. CE; cf. L. D’AMORE, “Una preghiera esorcistica da Reggio Calabria (VII-VIII secolo)", MedAnt 7.2, 2004, p. 751-770), which contains an invocation of the Triad for the protection of the bearer from evil, migraine, head-ache, impure spirit ( $\pi \tilde{\alpha} \nu \dot{\alpha} x \dot{\alpha} \theta \alpha \varrho \tau o \nu$ $\pi \nu \varepsilon \tilde{u} \mu \alpha)$ and inflamation of the eyes.

52) K. GÖRKAY, “A Building Inscription from Erythrae: A Temple or Sacred Chamber to Dionysus Propator, Antoninus Pius, and His Sons”, in Festschrift für Elmar Schwertheim I, p. 269275 [BE 2009, 27]: A new fragment of I.Erythrai 132 permits a better reconstruction of this inscription (Erythrai, $161 \mathrm{CE})$. It commemorates the dedication of a bieros oikos to Dionysos Propator, Antoninus Pius, Lucius Verus, and Commodus by a priest of Dionysos and a second individual at their expense. G. interprets the epithet propator as referring to a paternal association between the god and both the Dionysiac artists and the imperial family (perhaps traced back to the support offered by Hadrian to the Dionysiac artists). Hadrian was worshipped as 
Neos Dionysos and his visit to Erythrai in 123/124 CE was celebrated by the city with the agon Hadrianeia Epibateria (I.Erythrai 60).

53) M. GonZales, "New Observations on the Lindian Cult-Tax for Enyalios (SEG 4.171)", ZPE 166 (2008), p. 121-134 [BE 2009, 398]: G. republishes and translates the Lindian decree that concerns the payment by all soldiers of a 1/60-tax on their salary to Enyalios (SEG IV $171=$ LSCG Suppl. 85). Following W.K. Pritchett's interpretations of o[i $x \alpha] \sigma \tau \varrho \alpha \tau \varepsilon[\dot{\omega} \omega] \nu \tau \alpha \iota$ ह่ $x$

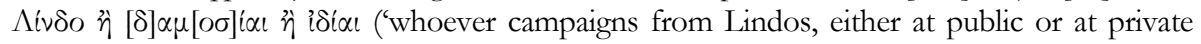
expense'), G. argues that the text envisages soldiers paid by the state $([\delta] \alpha \mu[o \sigma] i \alpha \iota)$ and soldiers paid privately ( $(\delta i \alpha \iota)$; this decree should be seen in the context of Rhodian military euergetism. [The aim of the decree was to make sure that all soldiers paid a due to Enyalios; for its proposer, it was irrelevant who sponsored their salary: the state or a benefactor. On the contrary, what was relevant was that soldiers employed by others than the Lindian community would not evade this taxation. This is why I prefer the traditional interpretation: 'whoever participates in a public or private military expedition setting out from Lindos'. The text makes a distinction between soldiers participating in campaigns of the community and mercenaries.] G. also studies the topography of the shrine of Enyalios and the cult of this god, especially the sacrifice of a boar, a dog, and a kid.

54) Gorny \& Mosch, Giessener Münz̧handlung. Auktion 150. Kunst der Antike, 11. Juli 2006, Giessen, 2006 [SEG LVI 2041-2042]: The inscribed objects offered for sale include a dedication to Leukothea after a prayer ( $\varepsilon \dot{\jmath} \xi \dot{\alpha} \mu \varepsilon[\operatorname{voc}] ;$ unknown provenance, 4th/3rd cent., 117 no 308; text read by R.A. TYBOUT in SEG).

55) GoRny \& Mosch, Giessener Münz̧andlung. Auktion 154, Kunst der Antike, 12. Dęember 2006, Giessen, 2006 [SEG LVI 2045]: The objects offered for sale include the following (texts read by R. TYBOUT in SEG). 1) A votive relief of unknown provenance (2nd/3rd cent., 123 no 315). It was dedicated to the Fair Maidens ( $x \alpha \lambda \alpha i \varsigma$ xó@ $\alpha \iota \varsigma)$ by two women in fulfilment of a vow

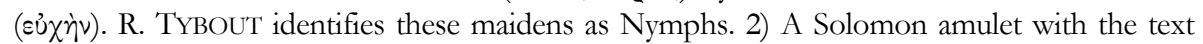

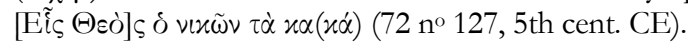

56) P. Gouw, "Hadrian and the Calendar of Greek Agonistic Festivals. A New Proposal for the Third Year of the Olympic Cycle", ZPE 165 (2008), p. 96-104: The letters of Hadrian from Alexandreia/Troas provide valuable information concerning the organisation of agonistic festivals during his reign (see EBGR 2007, 111). G. proposes a new interpretation of the passage that refers to the festivals that took place in the last two years of the periodos. According to the ed. pr., the Panathenaia took place in July/August of the third year whereas the Pythia and the Isthmia took place in the fourth year of the periodos. G. presents a different reconstruction of the sequence of festivals in the third year: Panathenaia in Athens (spring), Koina Asias in Smyrna (mid-April), Koina Asias/Augousteia in Pergamon (late May), Hadrianeia in Ephesos (early July), Pythia in Delphi (late August), Isthmia in Corinth (autumn).

57) F. GRAF - S.I. Johnston, Ritual Texts for the Afterlife. Orpheus and the Bacchic Gold Tablets, London-New York, 2007 [BE 2009, 298]: The authors present 39 Orphic tablets (Greek text and translation) and a thorough study of their content and religious context. Inter alia, they summarize the history of research and discuss the relevant myth of Dionysos, the eschatology behind the tablets, and the initiation rites. In an appendix, they present inscriptions from Olbia that have been associated with the Orphic circle (IGDOP 92, 94, 95), col. I of the Gurôb Papyrus 1, and the edict of Ptolemy I concerning Dionysiac initiations (late 3rd cent.).

58) E. GRZYBEK, “Rhodische Inschriften”, ZPE 165 (2008), p. 67-83 [BE 2009, 399]: Ed. pr. of two honorary inscriptions from Rhodos (early 1st cent.). According to the first text the cult

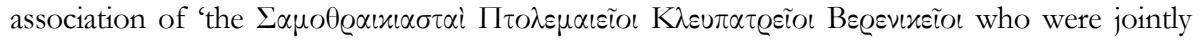


initiated in the mysteries of Samothrace together with the archon Andronikos' honoured a certain Apollodotos. The association's name implies that it was founded in honour of the Ptolemaic royal family (probably of Ptolemy IX, Kleopatra IV and Berenike III, c. 116-80). At least an additional seven associations of Samothraciasts existed in Rhodes: $\Sigma \alpha \mu o-$

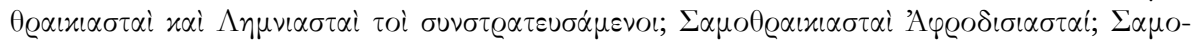

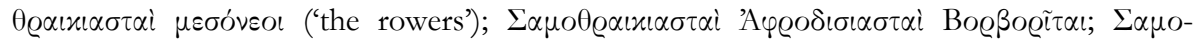

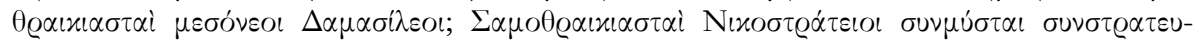

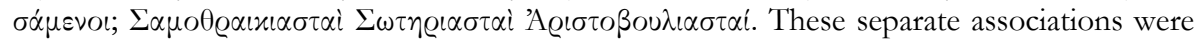
defined according to different criteria, such as the occupation of their members, the worship of an additional deity, their different founders, and the joint initiation of their members in the Samothracian mysteries. Apollodotos is known also from a list of the members of an association who had donated gold crowns and silver masks (MAIURI, Nuova Silloge 27a); Apollodotos' presence in this association suggests that the association was dedicated to the worship of the Samothracian Gods. The second honorary inscription was set up for Apollodotos' father who served as choregos of the pyrrbiche-dance and who had won a competition at the Halieia.

59) W. GÜnther, "Pan im 'Hain des Phoibos'. Zu einem Inscriftenfund aus Didyma”, in R. BIERING - V. BRINKMANN - U. SCHLOTZHAUER - B.F. WEBER † (eds), Maiandros. Festschrift für Volkmar von Graeve, Munich, 2006, p. 105-110: Ed. pr. of an interesting dedicatory epigram from Didyma (Miletos, 2nd/3rd cent.). It commemorates the dedication of a statue to Pan

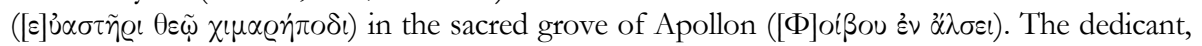

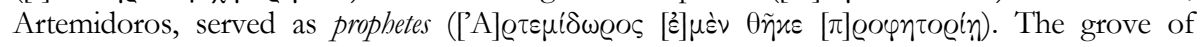
Apollon at Didyma is mentioned by Strabo (14.1.5; cf. MERKELBACH-STAubER, SGO I 84:

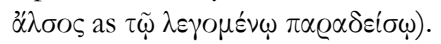

60) W. GÜNTHER, "Der Gott als Erbe - eine neue Inschrift aus Didyma", Chiron 38 (2008), p. 111-116 [BE 2009, 432]: Ed. pr. of an honorary inscription from Miletos. A certain Melanthios was honored for bequething his property to 'the god' and the people $\left(\varkappa \alpha \tau \alpha \lambda\left[\iota \pi{ }^{\prime}\right] \nu \tau \alpha\right.$

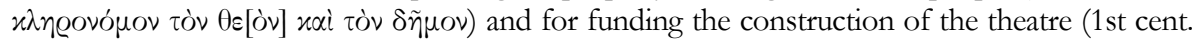
CE). A similar phenomenon, i.e. leaving one's property to the divine patron of a city, is attested in Ephesos (for Artemis Ephesia: I.Ephesos 612, 692, 731). The divine recipient must be Apollon Didymeus, since we know from Ulpian (FIR A II 285 cap. 22.6) that Apollon Didymeus was excluded from restrictions concerning sanctuaries as recipients of bequests.

61) A. Hajdari - J. Reboton - S. ShPuZA - P. CABAnes, "Les inscriptions de Grammata (Albanie)", REG 120 (2007), p. 353-394 [BE 2009, 604]: The authors present an overview of their research at Grammata (Illyria), where c. 100 graffiti have been recorded. These graffiti, from the 3rd cent. BCE to the Byzantine period, were written by sailors. The ancient graffiti address the Dioskouroi (and in a few cases Isis) as protectors of sailors. In an appendix 25 graffiti are presented. These graffiti usually consist of the formulaic expression घ̇ $\mu \nu \eta \dot{\sigma} \sigma \eta \eta \pi \alpha \varrho \dot{\alpha}$

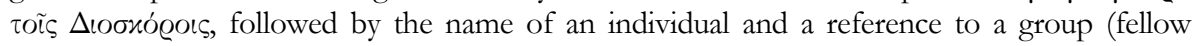
slaves, fellow soldiers, family members) with or for whom the commemorative inscription was written.

62) K. HALlOF, Inscriptiones Graecae. Voluminis IV edito altera, fasciculus II. Inscriptiones Argolidis, Fasciculus II. Inscriptiones Aeginae Insulae, Berlin, 2007: This IG volume contains the inscriptions of Aigina (746-1075) and pierres errantes found on this island (1076-1239). We only summarize the content of the Aiginetan inscriptions. On the inscription that mentions Zeus Pasios (1061) see infra no 134. Myths: An honorary decree for Attalos I refers to the kinship of Aiakos and Herakles. Dedications: to Aphea (*1023, 1024-1035), Athena (755), Dionysos (*763), Herakles (1068), the Nymphs (*1069), Pan (*1036), Zeus and Athena (765, by soldiers), Zeus, Athena, 
and Artemis (767), and anonymous deities (756-759, *761, 762, *766, 770; unclear: 764). Several dedications are connected with the heroic cults of Thebasimachos (754), Ion (769), and

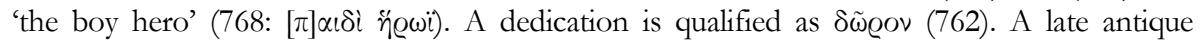
epigram, inscribed on the base of a statue of Pan, is an interesting piece of evidence for late paganism (786, $359 \mathrm{CE})$. Festivals: A series of inscriptions (835-847, 3rd cent. CE) commemorated banquets $(\delta \eta \mu о \theta o v v \dot{\sigma} \sigma \alpha)$, to which the sponsors invited the 'sacred pentapolis' (835:

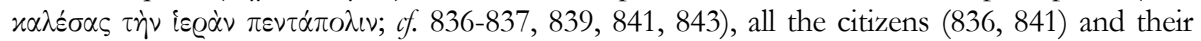
wives (841), and many slaves $(835,841)$, and made the customary donations to the council (838). Announcements were made during the dramatic contests at the Attaleia, Eumeneia, and Nikephoria (749), Dionysia (749-750), Herakleia (750), and Rhomaia (750). The grave epigram for the boy Themistokles mentions the fact that he had won an agonistic festival (933: $\pi \alpha \tilde{i} \delta \alpha$ $\left.\alpha \varepsilon \theta \lambda \circ \varphi o_{\varrho} \circ v\right)$. There are also references to a beorte (751) and a sacrifice $(* 752)$ in unclear contexts. Sanctuaries: Two inventories list cult objects and dedications in the sanctuaries of Mnia and Auxesia (787, late 5th cent.) and Aphea (1037). A building inscription in the sanctuary of Aphea commemorates the construction of an oikos, an altar, the ivory parts of a statue

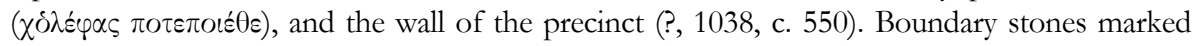
precincts of Athena (792-797), Apollon Patroios (*789), Apollon and Poseidon (798-801), Zeus (*791), Zeus Hellanios (1055-1057), and anonymous gods (788, *790, 802-804). It is unclear whether an inscribed stone mentioning Aphrodite Epilimenia was a boundary stone (or an anchor?, 1005). Ruler cult: The Attaleion is mentioned in an honorary decree for a Pergamene officer (749 line 46). The recipient of a dedication who is called $\alpha \dot{\varphi}$ ' 'H $\lambda$ íou véos

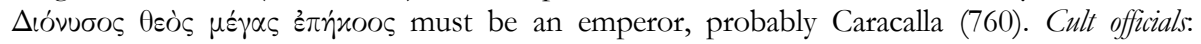
agonothetes (782), priest of Aphea (1038). Cult associations: Three epitaphs mention thiasitai (968) and thiasoi $(971,972)$ among those who offered funerary crowns. Funerary cult. A funerary

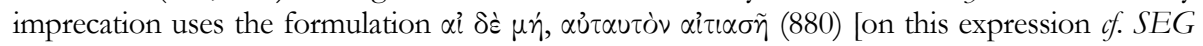
XXVI 1225; I.Ephesos 568; I.Tralleis 245]. An epigram for a boy refers to the inescapable power

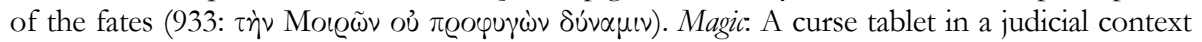
(*1012, 5th/4th cent.) is fragmentary, but one recognizes a bistoriola: 'just as Hephaistos bound ... and as Zeus, son of great Kronos, bound Prometheus with force and might ...', in the

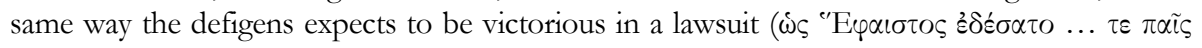

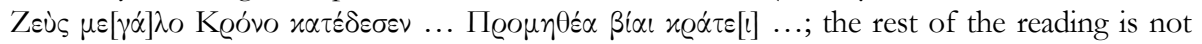
clear, probably because of scribal errors. J. Curbera (apud IG) plausibly suspects that this is what the scribe intended to write: $\dot{\omega} \varsigma$ "H An amulet (1011, Late Antiquity or later) mentions Abrasax, Iao, and the seven angels.

63) K. HALLOF, “Ein Dekret aus Kyzikos?”, in Festschrift für Elmar Schwertheim I, p. 309-311: A re-examination of epigraphic fragments from Kos reveals that they belong to a single opisthographic stele containing decrees concerning the asylia of Kos and the expansion of the agon of the Asklepieia (SEG LIII 852+853; cf. EBGR 2003, 18). Six decrees on side B were issued by cities in Asia Minor, visited by the architheoros Hippotas; these cities include Kalchedon, Kios, Kyzikos (?), and unknown Ionic cities. This sequence reflects the itinerary followed by the theoroi. Three decrees on side A were issued by Aeolic cities. H. presents the text of the decree that can be attributed to Kyzikos.

64) J. HAMmerstaedT - M.F. SMith, "Diogenes of Oinoanda: The Discoveries of 2008”, EA 41 (2008), p. 1-37 [BE 2009, 471]: Ed. pr. of new fragments of the inscription containing excerpts of the philosophy of Epicure from Oinoanda. In one of the fragments (NF143) the Delphic oracle is criticized with reference to the oracle given to Croesus: 'Why does he (Apollo) give oracles to any who want them against those who have committed no sin, either

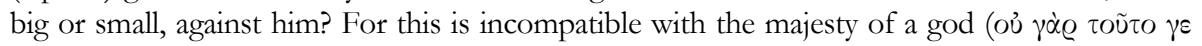

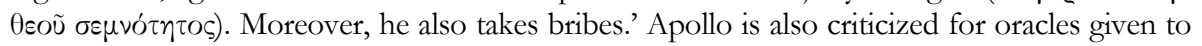


Archilochos, but only the beginning of the relevant passage is preserved. Another fragment (NF155) preserves a maxim, probably composed by Diogenes and expressing the view that the world was not created by a divine creator and is perishable: 'Although Plato was right to acknowledge that the world had an origin, even if he was not right to introduce a divine craftsman of it, instead of employing nature as its craftsman, he was wrong to say that it is imperishable.'

65) P. HAmon, "Kymè d'Éolide, cité libre et démocratique, et le pouvoir des stratèges", Chiron 38 (2008), p. 63-106: In a study dedicated to the office of the strategoi in Kyme, H. presents an improved edition of a decree concerning this office (see infra $\mathrm{n}^{\circ} 108$ ). In lines $9 \mathrm{f}$. he restores

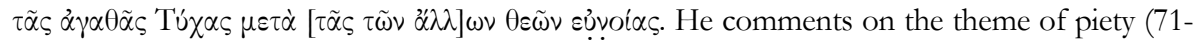
74; cf. the invocation of Zeus Heraios, Zeus Basileus, Zeus Homonoios, Homonoia, Dike, Epiteleia ton Agathon in the reconciliation decree of Mytilene: SEG XXXVI 750). The gods

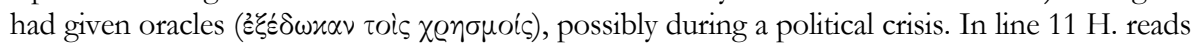

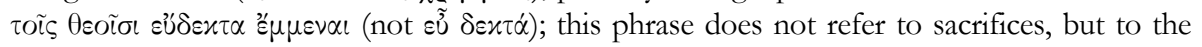
favourable reception of the decree by the gods.

66) A. Herda, Der Apollon-Delphinios-Kult in Milet und die Nenjabrsprozession nach Didyma. Ein neuer Kommentar der sog. Molpoi-Satzung, Mainz, 2006: H. presents a critical edition and a thorough commentary of the cult regulation of the Milesian molpoi (LSAM 50; Milet I.3.133). He argues that the rites of the molpoi, rites of very ancient origin, were written down in the late Archaic period (c. 540 or 525) and underwent several revisions until the late Hellenistic period (c. 200). According to his interpretation, the largest part of the inscription treats rituals of the festival of Apollon, which started on his sacred day (the 7th of Taureon) and continued to the 10th of the month. This festival was the New Year's festival in Miletos, which included the inauguration of the new aisymnetes, the oath of the representatives of the tribes, sacrifices performed by the stephanephoroi, i.e. new and the retiring asymnetes. In connection with this festival, the young men of Miletos completed their 'initiation cycle' and were accepted into the citizen-body, performing choral contests. After these rites for Apollo Delphinios on 10th Taureon a procession from Miletos to the sanctuary of Apollo in Didyma took place. [For some criticism and a more detailed summary see my review "The Molpoi Inscription: Ritual Prescription or Riddle?”, Kernos 23 (2010), p. 375-379.]

67) A. Hermary, "Un nouveau vase inscrit de Kafizin”, CCEC 36 (2006), p. 63-72 [BE 2008, 118; SEG LVI 1830 ter]: More than 300 inscribed vases were found in the sanctuary of the Nymphs at Kafizin on Cyprus (T.B. MITFORD, The Nymphaeum of Kafizin. The Inscribed Pottery, Berlin, 1980). They are connected with the rituals of an association. H. publishes a new inscribed vase dedicated by Onesagoras, who is known from several other dedications $(224 / 3$ $\mathrm{BCE})$. The vase is decorated with alternating bearded heads and branches or small trees. The

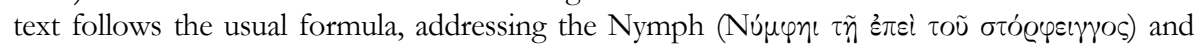

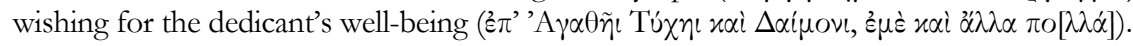

68) A. Hermary, "L'offrande de la Parienne Krinô à l'Artémis Délienne”, in E. Simantoni-

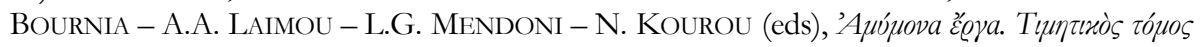

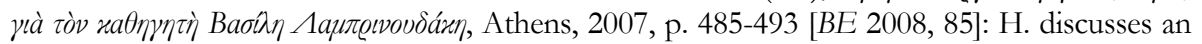
inscription from Delos (I.Délos 53, 4th cent.) recording the dedication of a statue by Krino of Paros to Artemis Delia. Krino fulfilled a promise made by her father ( $\pi \alpha \tau \varrho o ̀ \varsigma ~ i \pi \circ \sigma \chi \varepsilon \sigma i \eta \eta$,

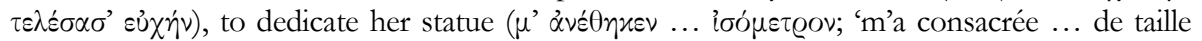

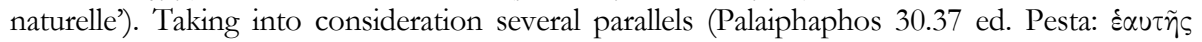

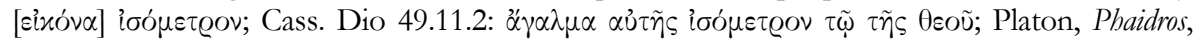

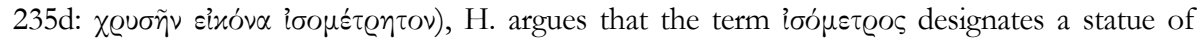
exactly the same size as Krino. He observes that the vertical arrangement of the inscription 
imitates the arrangement of inscriptions on Archaic columns or pillars supporting statues (e.g. I.Délos 15) and adduces a contemporary statue of Artemis Delia dedicated by Areis of Paros (IG XII 5, 211) as an example of an archaising dedication [on Apollon Delios and Artemis Delia see EBGR 2006, 54]. The remains of Krino's feet on the plinth show that she was represented in an archaising posture, with one supporting leg and the other slightly bent. In Athens, the thesmothetai who violated a law were expected to dedicate a statue of their size in Delphi (Plut. Solon 25.3). It is not clear whether the promise made by Krino's father was connected with a wrongdoing. [In cases of wrongdoing, the wrongdoer, the dedicant, and the individual whom the image represents are one and the same. It is more probable that Krino's father vowed to dedicate a statue in his daughter's size if she successfully faced a disease or another crisis.]

69) P. HERRMANN - W. GÜNTHER - N. EHRHARD, Inschriften von Milet. Teil 3. Inschriften n. 10201580, Berlin, 2006: This volume presents 561 inscriptions from Miletos, including many inedita. Many of these texts are of great religious interest. For the honorary inscription for C. Iulius Epikrates (1131) and its relation to the imperial cult see EBGR 1994/95, 166. Cult regulations: Many cult regulations included in $L S A M$ are republished: a cult regulation concerning sacrifices $(1217=L S A M 43)$; decrees concerning priestly perquisites $(1219=L S A M 44$; $1220=L S A M 45 ; 1221=L S A M 46)$; a regulation concerning the sale of the priesthood of Dionysos (1222 = LSAM 48); a regulation concerning the cult of Artemis Boulephoros Skiris $(1225=L S A M 47)$. Three fragments consisting of a few letters $(* 1215)$ are part of the Archaic sacrificial calendar (LSAM 41). Among the new cult regulations, most of which are very fragmentary, the most important text is a decree concerning the foundation of a sanctuary and the establishment of a new cult upon an oracle (*1224, early $3 \mathrm{rd}$ cent.). The people were to provide the necessary funds for a sacrifice and an agersis, probably collection of gifts (lines 6-8); these expenses were to be included in the budget for the month Anthesterion. A small fragment mentions the Nymphs (*1216). A decree concerns the cult of Poseidon Helikonios (1218, 437/6 BCE), another fragmentary decree pertains to the priesthood of another god (Dionysos?, *1223). It is not clear whether a small fragment that mentions Artemis $(* 1437)$ is part of a cult regulation.

Myths: An honorary inscription for Julian mentions the fact that Miletos was the 'nourisher of

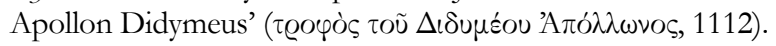

Dedications: A man is honoured for dedicating bowls to Apollon Termintheus in Myous (1029). Dedications are addressed to: Aphrodite (1280-1281, *1282-*1283), Aphrodite in Oikous (1279), Aphrodite Ourania (*1285), Apollon (*1237, a tripod; *1238), Apollon Auleites (*1226), Apollon Didymeus (*1227-*1231), Artemis Kithone (1239, a perirhanterion), Artemis Lochie (*1240), Athena (1272, by a victorious athlete; 1273-1274, *1275), Athena Assesia (1276-1278), Demeter (*1289), Demeter Argasis (*1288), Dionysos $(* 1291)$, Dionysos and Artemis $(* 1292)$, Dionysos and the Muses $(* 1293$, by a victor at the Mouseia in Thespiai),

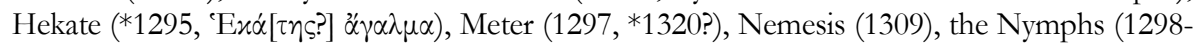
1300), Poseidon Asphaleios (*1317), Theos Hypsistos (*1255), Zeus (*1264?), Zeus Helios (*1261), Zeus, Hermes, and the Olympian gods (*1263), Zeus Labraundos (*1267), Theoi Pantes (*1313), Egyptian gods (Boubastis: *1301; Horus Apollon Harpokrates epekoos:

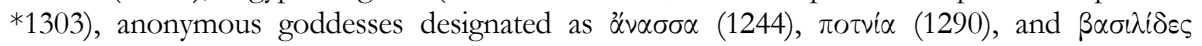
( $* 1305$, possibly Demeter and Kore: a woman dedicated a megaron), and a god designated as $\beta \alpha \sigma \iota \lambda \varepsilon \dot{s} \zeta \ddot{\alpha}^{2} \alpha \xi(* 1304$, the autochthonous Anax and king Asterios?); the recipient is not known in several cases $(* 1314, * 1316, * 1318, * 1319, * 1321-* 1322)$. The cause of the dedication is sometimes mentioned: fulfilment of a vow (Ẻ் $* 1283, * 1288, * 1289, * 1304,1309, * 1321)$, offering of a tithe (1279: $\delta \varepsilon x \alpha \dot{\tau} \tau)$, and expression of

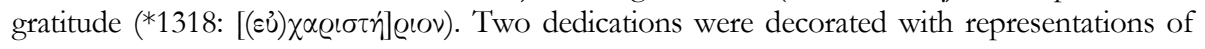


ears in relief, an allusion to the willingness of the god to listen to a prayer $(1303,1320)$. Altars were erected for Aphrodite Ourania (*1284), Apollon Didymeus (*1232), Apollon Didymeus and Artemis (*1233), Apollon Didymeus Soter (*1234-*1236), Apollon Didymeus Soter and

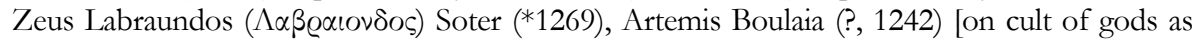
boulaioi see EBGR 2006, 57], Artemis Pyth(e)ie (*1241), Artemis Pythie, Hadrian, and Zeus

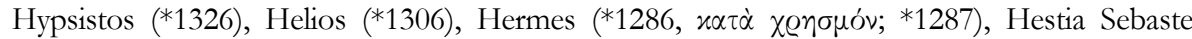
(*1307), Isis (*1302), the Kairoi (*1308), Poseidon Asphaleios (*1294, $x \alpha \tau \dot{\alpha} \chi \varrho \eta \sigma \mu o ́ v)$, Tyche

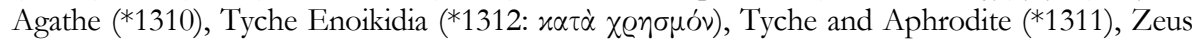
Soter, Leto, Apollon, and Artemis (*1245), Zeus Soter (*1246-*1247), Zeus Aitherios Soter and Apollon Didymeus (*1248), Zeus Apa[-- $(* 1249)$, Zeus Apotropaios (*1250), Zeus

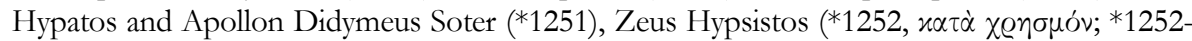
*1253), Zeus Kataibates (*1256), Zeus Keraunios Soter (*1257), Zeus Kronion (1258), Zeus Labraundos (*1265-*1266), Zeus Labraundos and Zeus Lepsynos $(* 1270$, $\alpha \varphi i \delta \varrho \cup \mu \alpha)$, Zeus Larasios and Hera (*1271), Zeus Megistos Helios (*1260), Zeus Olympios Pisaios (*1259), and an anonymous god (1315). We notice an unusually large number of oracles (of Apollon at Didyma) requesting the erection of altars for the cult of various gods ( $\varkappa \alpha \tau \dot{\alpha} \chi \varrho \eta \sigma \mu o ́ v: * 1252$, $* 1268, * 1286, * 1294, * 1312)$. In one case the inscription provides more information (*1268). Poseidonios erected an altar upon an oracle ( $\beta \omega \mu$ ò $\varkappa \alpha \tau[\grave{\alpha}] \chi \varrho \eta \sigma \mu o ́ v)$ fulfilling a vow to the

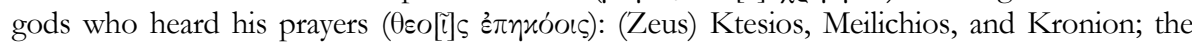
name of Zeus Labraundos ( $\Lambda \alpha \beta \varrho \varepsilon v \delta \circ \varsigma)$ was added later to this list. The $\Delta i o ̀ \varsigma ~ ' E \lambda \pi i \delta \omega \nu \beta \omega \mu$ ' (*1262) may be an altar of 'Zeus of the Hopes' or 'the Hopes of Zeus' [rather of 'Zeus and the Hopes'; as N. EHRHARD points out, there is a dedication for Elpides Agathai in Miletos (Milet I.7.286). The cult of some personified emotions (Phobos, Eros) is attested]. A relief has labels of the represented figures: Kourotrophos, Leto, Apollon, and Artemis (1296).

Festivals: An inscription found in Kos contains the Milesian decree concerning the upgrading of the Didymeia to a 'crown contest'. The decree mentions the consecration and asylia of Miletos and its territory because 'of the union of Zeus and Leto that took place in this site and because of the god's oracles'; an embassy was to be sent to Kos in order to invite the Koans to the festival (1052, c. 210). A letter of Marcus Aurelius and Commodus confirms the promotion of an existing context (probably the Megala Didymeia Kommodeia) to the rank of an eiselastic contest $(1075,177 \mathrm{CE})$. A decree honouring an athlete, probably a winner at the Olympic games, is an interesting piece of evidence for the material rewards of victorious athletes; he received a crown worth 50 Dareikoi (*1022, c. 350) [cf. EBGR 2007, 112]. Agonistic inscriptions (1363-1370, of. 1443-1444) mention the following festivals: Isthmia (*1363), Nemea, Heraia, Sebasta in Neapolis, Koina of Asia in Laodikeia, Eleutheria in Plataia, Didymeia, and Pythia in Tralleis (*1365), Pythia, Aktia, Balbilleia in Ephesos, Kaisareia in Isthmos, Aspis in Argos, Koina of Asia in Pergamon (*1366, a boy wrestler who later turned into a pankratiast); Pythia, Kapitolia (1367-1370). Honours were announced at the Dionysia in Miletos $(* 1026, * 1030, * 1033,1038,1039)$. A small fragment of an imperial letter seems to refer to privileges of the Dionysiac artists $(* 1079)$. An Athenian decree honours the members of a Milesian delegation (architheoros, theoroi, 1038, 2nd cent.).

Sanctuaries: Public documents were set up in the sanctuary of Apollon Delphinios (1023, 1055 and Apollon Termintheus in Myous (*1030, 1040). For a temple inventory (1357) see EBGR 1988, 63. Two further temple inventories from the sanctuary of Apollon Didymeus list clothing items and metal objects (*1358-*1359).

Ruler cult: A decree concerns the creation of a priesthood for Eumenes II and provides for the election of a committee which would draft the conditions for the sale of the priesthood (1040, c. 158). An altar for Arsinoe Philadelphos (*1323) is to be added to the abundant evidence for her cult. As regards the imperial cult, Drusilla was identified with Aphrodite (*1095) and 
Hadrian received numerous dedications, in which he is identified with Zeus Olympios (*1327$* 1331,1338, * 1342-* 1343)$ and Zeus (1337) and honoured as saviour (soter), oikistes, and benefactor $(* 1324-* 1326,1327, * 1328-* 1334,1335, * 1336,1337-1338, * 1339,1340, * 1341$, $* 1342, * 1344)$; in some cases he received dedications jointly with the local gods, Apollon Didymeus $(* 1333, * 1347, * 1349)$ and Artemis Pythie (*1346; cf. 1326). The emperors, to whom three other dedications were made $(* 1350-1352 ; * 1352$ jointly with Apollon) cannot be identified. For priests of the imperial cult see infra. There is evidence for the organisation of gladiatorial combats and venationes in connection with the imperial cult (1141; of. 1371-1378).

Rituals: A decree concerning taxes contains prescriptions for the oath ceremony: 'they shall stand in front of the altar and they shall be sworn by the high priest and the magistrates who

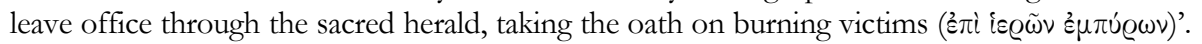
Apollon Didymeus and Caesar Augustus are invoked in the oath (1044, 1st cent. BCE/CE). An honorary inscription for prytaneis (1425) lists the services that they performed, including

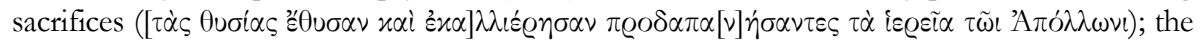
text also mentions a ir@ò $\pi \alpha \tilde{\iota} \varsigma$, a slave owned by the sanctuary. A procession is mentioned in a small fragment (*1457). A decree concerning isopolity with Amyzon (found in Amyzon, Hellenistic) mentions a prayer addressed to Apollon Delphinios and the other gods in his

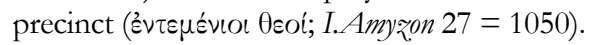

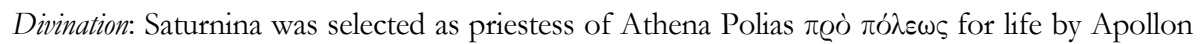

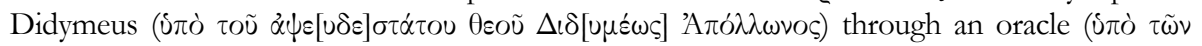

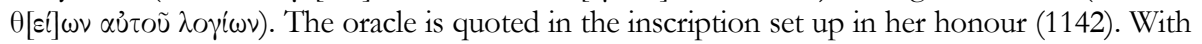
its 15 hexameters, it is the longest metrical oracle from Didyma; it refers to Athena's birth, highlights her importance as protector of citadels and the arts, and recommends the selection of a married woman of noble birth as her priestess. This text is of interest for its reference to the reliability of Apollon's oracles ( $\dot{\psi} \psi \varepsilon[0 \delta \varepsilon] \sigma \tau \dot{\alpha} \tau o u ;$ cf. SEG XL 956; I.Didyma 83). For four other oracles, published recently (1353-1356), see EBGR 2002, 41.

Priests and cult officials: These inscriptions attest to numerous priesthoods and religious functions, very often connected with the cult of Apollon in Didyma. Priesthoods: priest of

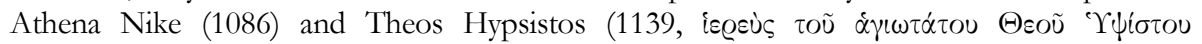
$\left.\sum \omega \tau \tilde{\eta} \varrho \circ\right)$ ); priestess (propolos, of Artemis Boulaia?, 1242); priestess for life of the Kouretes (*1384); high priest of the civic imperial cult $(1130,1141, * 1460)$; high priestess of the civic imperial cult $(1142, * 1160)$; high priest of Asia/Asiarches (1126, 1127, 1131, 1136, 1142, 1146, $* 1147, * 1431)$. Other functions: agonothetes of the Megala Didymeia Kommodeia (*1143, *1152; cf. *1426; agonothetes and panegyriarches: $1145, * 1151, * 1162, * 1431$ ?); amphithales and eisagogeus of the Megala Didymeia Kommodeia (1140; the amphithales cut the branches from the sacred tree for the winners of the contest; the eisagogeus introduced the competitors); bydrophoros of Artemis Pythie $(* 1177, * 1178, * 1384, * 1427)$; hypochrestes of the oracle of Apollon Didymeus (1145, $* 1174)$; kotarchos (i.e. priest of the Kabeiroi, *1174), prokitharistes and pyrphoros of Apollon Delphinios (1140) [on prokitharistes see EBGR 2006, 3]; prophetes (*1143, *1151, *1174); prophetes

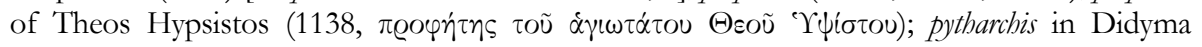
$(* 1292)$. There are several instances of accumulation of priestly offices: 1131, 11401143 , *1151, *1174. Apollon served as stephanephoros (1056). Associations: Apellas, a prokitharistes of

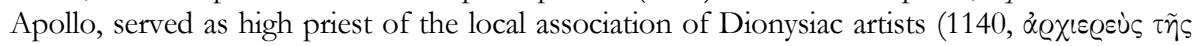
$\tau \circ \pi \varkappa \tilde{\eta} \varsigma$ $\sigma u v o ́ \delta o u)$. A boundary stone marked the temenos of the Xynchidai, a family group or an association $(* 1385)$.

Varia: An unusual text is a list of epithets of Zeus, perhaps from a gymnasium (1395); the

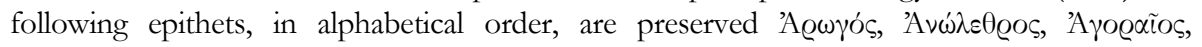

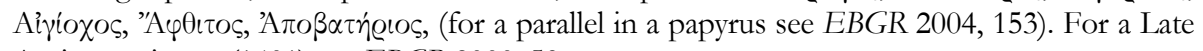
Antique epigram (1401) see EBGR 2000, 53. 
70) G.H.R. HorsLey, The Greek and Latin Inscriptions in the Burdur Archaeological Museum, London, 2007: Corpus of inscriptions preserved in the Museum of Burdur (Pisidia). We do not list the inscriptions that we have already summarized in EBGR 1992, 31 (21); EBGR 1999, 52 (dedications to Rider Gods); EBGR 2000, 79 (10 = 104d; 12 = 104e); EBGR 1994/95, 98 (dedications to the Dioskouroi); new texts are marked with an asterisk; all texts date to the

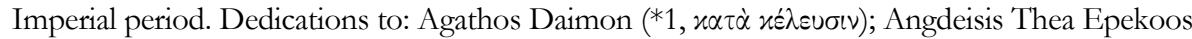
(2, by a priestess); Apollon (3-4, *5, *6, 7, *8, 9-12, *13, 17, *18), Apollon at Perminous/of the Perminoundeis (14, 15; cf. EBGR 2000, 79), Apollon and Hosion kai Dikaion (*19), Artemis epekoos (20, by a sacred slave, bierodoulos), Asklepios epekoos (*23, a statue of his mother, Koronis), Demeter and Kore, kyriai $(* 24$, by a didaskalos) [the dedicant does not have a patronymic, possibly a slave], Dionysos $(* 25$, by a couple serving as priests; $c$. 114$)$, the Dioskouroi (26-35; nos 36-45 are anepigraphic; 31: epekooi; enangelioi: 32; soteres. 33, 34), Hagnai Theai (48-49, both by the same retiring priest), Hera epekoos ( $* 50$, by a hierodoulos; $* 51)$, Herakles $(* 52, * 53,54-57,59-62, * 63,64-65, * 66,67-82$; in nos $79-83$ Herakles is called $\theta \varepsilon o ̀ \varsigma$ 'H@ $\alpha \lambda \lambda \tilde{\eta}$;; $\mathrm{n}^{\circ} 58$ is anepigraphic), Herakasbos (83; a merging of Herakles and Kakasbos?), the Twelve Gods (46; 47 is anepigraphic), Hermes (*84, by a mason; *85-*86; 87-88 are anepigraphic), Hermes epekoos (89), Hosios Dikaios (*90, by a slave and his daughter), Hosios kai Dikaios (*91-*93), Kakasbos (94, *95, 96-102); a statue of Asklepios was dedicated to an anonymous god (*22). Three dedications were made upon divine command: $x \alpha \tau \dot{\alpha} x \varepsilon \dot{\lambda} \varepsilon v \sigma \iota \nu \tau \tilde{\omega} \nu$

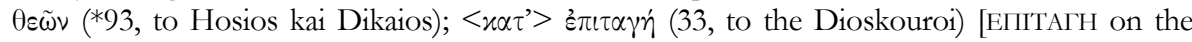

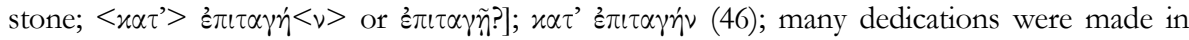
fulfilment of a vow: sủxท́: 4, 15, 80, *86; sủxท́v: 7, *8, 10-12, *13,14, *18, *19, 20, *24, 26-32, $34, * 50, * 51-* 53,54-57,59-62, * 63,64-65, * 66,67-77,79,81-83, * 85, * 90-* 93,94, * 95,96-102$;

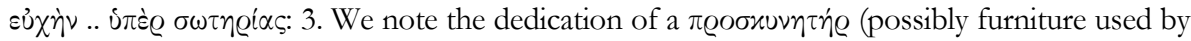
worshippers to prostrate themselves), a table for offering ( $\varrho \alpha \dot{\alpha} \varepsilon \zeta \alpha \nu)$, and wine mixing-bowl

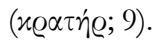

71) S. HuBER, “Un mystère résolu : Athéna sur l'Acropole d'Érétrie”, $A K 50$ (2007), p. 121 128 [BE 2008, 266]: In a report on excavations on the Acropolis of Eretria, H. mentions the discovery of a limestone statuette of a lion (of the "Cypro-Ionian" type). An inscription on the

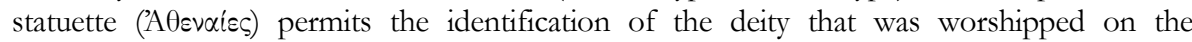
Acropolis as Athena (127).

72) J. Hupe, "Überlegungen zu den Statuenweihungen des Posideos an Achilleus und rhodische Gottheiten aus Neapolis Scythica", Eurasia Antiqua 9 (2003), p. 281-301 [SEG LV 849 bis]: H.

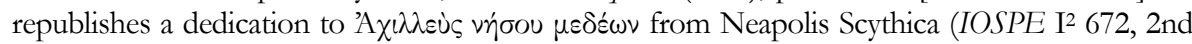
cent.). The dedicant, Posideos, is known as the sponsor of bronze statues dedicated to Zeus Atabyrios (IOSPE I2 670), Athena Lindia (IOSPE I² 671), and Rhodos (SEG LV 849 ter) in Neapolis, and to Aphrodite Euploia (IOSPE I ${ }^{2} 168$ ) in Olbia. Posideos' preference for Rhodian

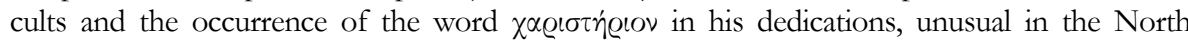
Pontic area, support the assumption that he originated in Rhodes or the Rhodian Peraia. As a member of the Rhodian aristocracy of traders, he entertained contacts with Olbia, where he was awarded citizenship. Because of his military experience in fighting against pirates, he was recruited by a Skythian dynast (King Skilouros?) to fight against the Satarchaioi (IOSPE I² 672).

73) S. ISAGER - L. KARLSSON, "A New Inscription from Labraunda. Honorary Decree for Olympichos: I.Labraunda no. 134 (and no. 49)", EA 41 (2008), p. 39-52 [BE 2009, 47]: Ed. pr. of a large fragment of a stele from Labraunda, which joins an already published small fragment (I.Labraunda 49, c. 150-100). The stele contains an honorary decree - probably of Mylasa - for Olympichos, a Karian dynast in the late 3rd cent., establishing a commemorative anniversary for the restoration of freedom and democracy and introducing his cult. The beginning of the 
text is lost and only the section containing the honors is preserved. A bronze statue group was to be erected in the 'sacred agora' (restored), depicting Demos crowning Olympichos. Opposite this statue group an altar was to be erected 'similar to the one for Maussollos in the sanctuary of Zeus Labraundos. In his honor a procession and a sacrifice shall be performed

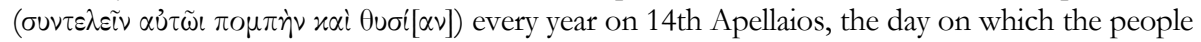

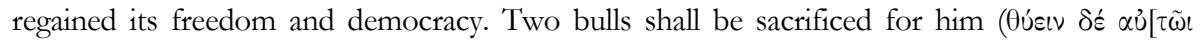
$\tau \alpha \dot{\varrho} \varrho 0]$ us $\delta \dot{o} o$ ) and the priests, the winners in crowned contests and the board of magistrates shall participate in the banquet $(\varepsilon \dot{\omega} \omega \chi \varepsilon \tilde{\tau} \sigma \theta \alpha)$. The priests shall take care of the sacrifice and the banquet ( $\theta$ oiv $\left.^{\prime}\right)$, and the treasurers shall make the expenses from the common revenues. A

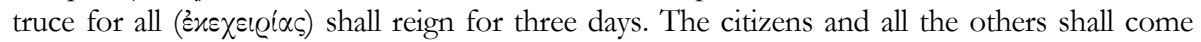

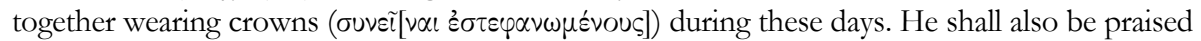
in a hymn during the quadrennial Taureia in the same way as for the city founders ( $\tilde{\mu} \mu \nu \varepsilon \tilde{\varepsilon} \sigma \theta \alpha \mathrm{l}$

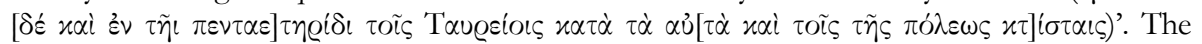
honors for Olympichos were to be announced during the athletic contest in honor of Zeus Osogo and the decree was to be set up in the sanctuary of Zeus Labraundos and in another location.

74) A.I. IvanchiK, “The First Steps of Olbian Epigraphy. An Unknown Manuscript of Egor Köhler", in Eucharisterion, p. 182-213 (in Russian) [BE 2008, 398]: Based on notes of Egor Koehler for $C I G$, now kept in the $I G$ archive in Berlin, I. publishes a fragmentary dedication to Apollon Prostates by a board of generals from Olbia (Imperial period, p. 209-212) and republishes a similar dedication of a silver statue of Nike (c. 220 CE; SEG XLVI 948 bis:

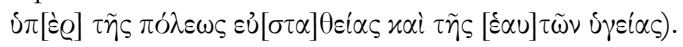

75) A.I. IVANTCHIK, "Une nouvelle proxénie d'Olbia et les relations des cités grecques avec le royaume scythe de Skilouros", in Une koinè pontique, p. 99-110 [BE 2008, 399]: I. presents a new edition of a proxeny decree of Olbia for a man from Smyrna (c. 150-100), combining three fragments (I.Olbia 27; SEG XXXI 712). Stephanos and his descendants were granted access to the council and the assembly immediately after the discussion of matters pertaining

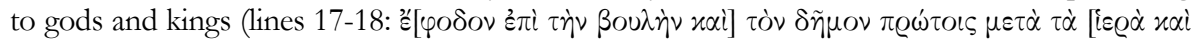
$\beta \alpha \sigma i \lambda(x \dot{\alpha}])$ and the right to offer sacrifices on the same altars as the citizens (lines 19-20: $\theta 0$ ev

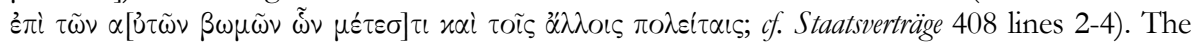
decree was published in the sanctuary of Apollon.

76) A. IVANTCHIK - V.V. KRApivina, "Nouvelles données sur le collège des agoranomes d'Olbia", in Une koinè pontique, p. 111-123: Ed. pr. of a dedication made to Hermes Agoraios by the board of agoranomoi for the well-being of the city and for their own health (i் $\pi \dot{\varepsilon} \varrho \tilde{\eta} \varsigma$

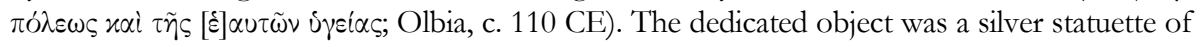
Nike. A second dedication by a board of magistrates is only partly preserved (c. $165 \mathrm{CE}$ ).

77) A.I. IVANCHIK, T.L. SAmojlova, "Sinkreticheskie kulty greko-egipetskikh bogov v Tire", in Bosporskë fenomen 2, p. 150-156: Ed. pr. of a dedication to Sarapis, Isis, and Anoubis and the synnaoi theoi (Tyras, 2nd/1st cent.). The authors discuss the evidence for the cult of the Egyptian deities at Tyras.

78) A.I. IVANTCHIK - V.P. TOlstikOv - A.V.KovalChuK, “A New Funerary Epigram from Pantikapaion”, VDI 260 (2007.1), p. 107-117 (in Russian) [BE 2008, 425]: Ed. pr. of a funerary epigram from Pantikapaion (1st cent. BCE/CE). The deceased person, a twenty-year-old man,

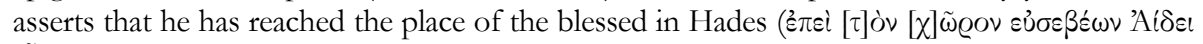
$[\tilde{\eta}] \lambda \theta \alpha ; c f$. IOSPE I 226 and CIRB 131).

79) C.P. JonEs, “Augustus and Panhellenes on Samos”, Chiron 38 (2008), p. 107-110 [BE 2009, 407]: A small fragment from Samos (IG XII.6.440) inscribed with a dedication to Thea Rhome 
and another deity or individual (line 1) and making reference to the Panhellenes (line 2) is a dedication to Augustus and not to Hadrian. Although Samos could have been a member of the Hadrianic Panhellenion, joint dedications to Dea Roma and another individual usually involve Augustus. Before Hadrian's Panhellenion, the league of various regions in central Greece (Boiotians, Euboians, Lokrians, Phokians) used the term Panhellenion as its name. The Panhellenes are also mentioned in an honorary inscription of Kolophon for Augustus (SEG XLVIII 1593, c. 30-27). J. argues that the Samian inscription was dedicated to Dea Roma and the later Augustus some time after the battle of Actium. In the inscriptions from Kolophon and Samos the term Panhellenes possibly designates the league of the Greeks of the province of Asia. They honored Octavian in Samos, one of his favorite places, which in this period unsuccessfully petitioned him to receive freedom (this privilege was granted later).

80) C.P. JonEs, “A Hellenistic Cult Association”, Chiron 38 (2008), p. 195-204: J. republishes a decree of an association issued after the death of the association's priestess (see EBGR 2007, 66). According to his translation of the opening phrase of the document ('the association of hero-worshippers who gather for Harpalos, Athenodoros, Menodote, and Zotas'), the decree was issued by an association dedicated to the heroic cult of these individuals. After her death, the priestess Stratonike was to join the group of the recipients of the rites. The word $\alpha \pi$ of $\varepsilon \omega \sigma \iota \varsigma$ is used in this text as an indication of the fact that the priestess has now joined the gods, rather

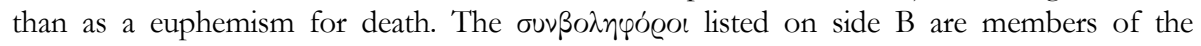
assocation who made contributions (not 'bearers of sacred symbols').

81) D.R. Jordan, “An Athenian Curse Tablet Invoking Palaimon”, in Mikros Hieromnemon, p. 133-144 [BE 2009, 177]: Ed. pr. of a lead curse tablet from Athens (late 4th cent.), the first Athenian defixio known with certainty to have been found in a shrine, that of Polykrates and Palaimon. Defixiones deposited in sanctuaries have been found elsewhere, mostly in sanctuaries of Demeter (Selinous, Rhodes, Mytilene, Knidos, Morgantina, Corinth). It was found rolled up and pierced with a nail. The text is written sinistrorsum. Two operations were envisaged: the first is analogical, in which the tablet itself was to represent the intended victims (backward spelling, piercing the tablet with a nail), the second is an appeal for vengeance for

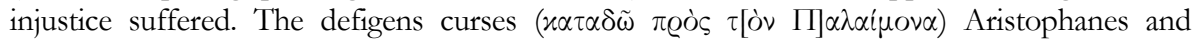
another seven men in the context of a lawsuit. 'I beseech you, o Palaimon: become a punisher of those whom I have listed for you, and to the judges let them seem to speak unjust things, and for the witnesses may what they do be useless. And bind their hands, tongue, soul, and their works, for unjust things they both do and say. Acting unjustly, may then (Aristophanes)

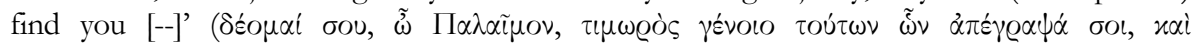

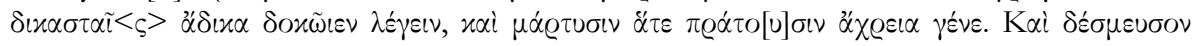

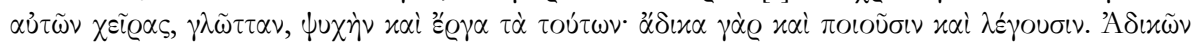

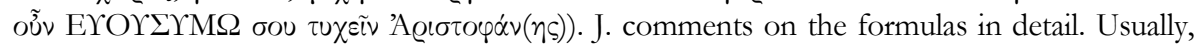

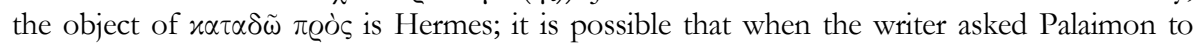
become his avenger, he was evoking the verb $\pi \alpha \lambda \alpha i \omega$ ('to wrestle'). The sanctuary of Palaimon was visited by the Sidonians; the defigens might have been a Sidonian himself. J. points to the affinity of this text with 'prayers for justice'.

82) D.R. Jordan-J. Curbera, "A Lead Curse Tablet in the National Archaeological Museum, Athens”, ZPE 166 (2008), p. 135-150 [BE 2009, 178]: One of the most famous and longest curse tablets, an Athenian defixio of the 4th cent. listing the names of almost one hundred individuals, has been associated with political conflicts in Athens (E. ZIEBARTH, "Neue Verfluchungstafeln aus Attika", SB Berlin 33 [1934], p. 1023-1027). However, the earlier editions were not accurate ( $c f$. D.R. JORDAN, "A Survey of Greek Defixiones Not Included in the Special Corpora", GRBS 26 [1985], p. 164 no 48). J.-C. present an improved new edition 
with detailed prosopographical commentary. The study of the prosopography shows that the traditional date around 323 BCE should be corrected (c. 345-335). Of the 98 individuals cursed, 30 are known Athenians, including both individuals known to have supported Demosthenes as well as some of the orator's opponents; consequently, a political motivation cannot be determined. In lines 119-123 four $\lambda \alpha \varkappa \alpha \dot{\alpha} \sigma \tau \varrho \alpha$ and a $\lambda \alpha \varkappa \alpha \sigma \tau \eta \dot{s}$ are cursed (i.e. individuals who performed fellatio) [see now S.C. HuMPHREYs, "A Paranoiac Sycophant? The Curse Tablet NM 14470 (D. R. Jordan and J. Curbera, “ZPE” 166, 2008, 135-150)”, ZPE 172 [2010], p. 85-86]. If these terms were not used merely in an insulting way, they may point to the particular occasion that originated the curse, possibly a conflict in an upper-class private club. The other victims include four women, two metics, and seven persons with professional designations (a painter, a secretary, and five traders). The text is written on both faces of a lead tablet. The curse formula $x \alpha \tau \alpha \delta \tilde{\omega}, x \alpha \tau$ $49)$ is written in larger letters that run across the top of the tablet; under this line the names of the cursed individuals are arranged in columns. This layout, known from official inscriptions, is connected with the known magical practice of using symbols of authority of the real-life world.

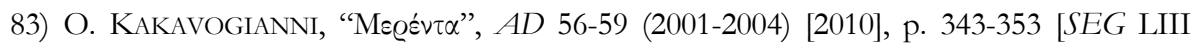
210]: Ed. pr. of a dedication to Zeus Phratrios by his priest found in a shrine of this god

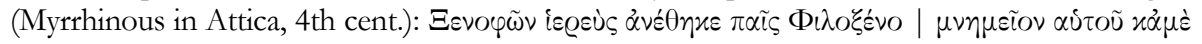

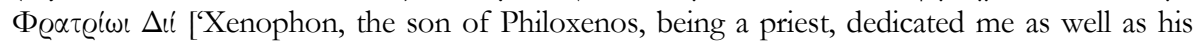
memorial to Zeus Phratrios'; the dedicated object was one of several dedications by Xenophon in commemoration of his service as a priest'].

84) M. KANTIRÉA, Les dieux et les dieux augustes. Le culte impérial en Grèce sous les Julio-claudiens et les Flaviens. Études épigraphiques et archéologiques, Athens, 2007 [BE 2008, 202; 2009, 297]: K. studies the early phase of the imperial cult in Greece (Athens, Peloponnese, Boeotia, Delphi, Lokris, Phokis, Thessaly, Keos). She discusses the historical background and predecessors of the imperial cult, i.e. the Hellenistic ruler cult and the cult of Roman generals as a response of Greek cities to benefactions (p. 21-39). The main part of the book is dedicated to the introduction of the cult of Augustus, its connection with the traditional pantheon of Greek cities, and the establishment of a dynastic cult during the Julio-Claudian era (41-84); the development of cultic honours under the Flavians (p. 84-87); the part played by the imperial cult in the urban space (sanctuaries, temples, dedications; p. 89-158); and the role of the elites in the development of the imperial cult (p. 159-193). In appendices she presents a selection of important epigraphic sources, a prosopography of 100 individuals connected with the imperial cult, and a list of imperial statues. Several tables list the monuments for emperors and members of the imperial family, joint dedications for emperors and gods, evidence for the assimilation of emperors and members of the imperial house with gods, agonistic festivals dedicated to emperors, honorary inscriptions for individuals involved in the imperial cult, and honorary inscriptions for emperors.

85) M. KANTIRÉA, “Le culte impérial à Chypre : relecture des documents épigraphiques", ZPE 167 (2008), p. 91-112: K. gives an overview of the imperial cult in Cyprus, focusing on the office of the high priest, the association of the imperial cult with traditional deities and cult places, the cult of the emperor in the gymnasium, and family relations between high-priests.

86) K. KARILA-COHEN, "La Pythaïde et la socialisation des élites athéniennes aux II et I Ier siècles avant notre ère", in J. COUVENHES - S. MILANEZI (eds), Individus, groupes et politique à Athènes, de Solon à Mithridate, Tours, 2007, p. 365-383 [BE 2007, 205]: A study of the prosopography of the Athenian lists of participants in the Pythais in 138/7, 128/7, 106/5 and 98/7 shows the predominant participation of members of elite Athenian families. This pilgrimage was an 
important factor in elite display and the creation of social identity [for an earlier article by the same author on the same subject see EBGR 2005, 76].

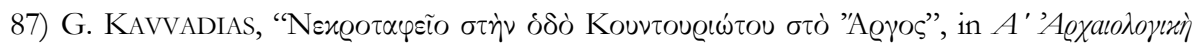

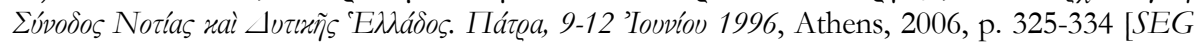
LIII 298 bis]: Ed. pr. of an interesting grave inscription for the athlete Demophilos (329-331 $\mathrm{n}^{\circ} 8$; Argos, 1 st cent. BCE/CE). The inscription was engraved on a memorial erected at public

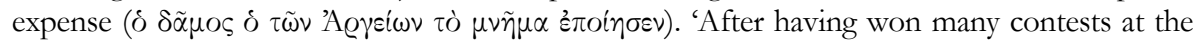
Nemeia, he considered it better to die in the stadium than to quit'. The memorial closes with a dialogue between Hades and the Sun. Hades says, 'I have never seen such a young man', and

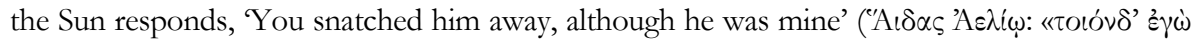

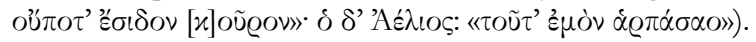

88) D. KNOEPFLER, Apports récents des inscriptions grecques à l'histoire de l'antiquité, Paris, 2005 [SEG LV 564bis]: In his inaugural lecture in the Collège de France, $\mathrm{K}$. discusses numerous new epigraphic finds, including a Boiotian inscription (p. 73-87), originally published by C.C. Vermeule III, Sculpture in Stone and Bronze in the Museum of Fine Arts, Boston. Additions to the Collections of Greek, Etruscan and Roman Art, 1971-1988, Boston, 1988, p. 27f. K. rejects an early Hellenistic date and shows that this text is not a dedication by an ambassador of the Arkadian Koinon but rather a decree of the Boiotian Koinon (c. 369/8). The relief in the pediment represents the boy Herakles strangling the snakes sent by Hera; a panel under the pediment is decorated with a representation of the Dioskouroi and Athena Alea; their names are inscribed on the upper frame of the panel; a lower panel is decorated with the prow of a warship. These images suggest that the honoured individual, the Lakonian Timeas, was a man from Therapne, where there were sanctuaries of both the Dioskouroi and Athena Alea. Therapne liberated itself from Spartan domination in 369/8, during Epameinondas' campaign in Lakonia; the combats took place near the sanctuary of Athena Alea and the house of the Tyndaridai (Xen., Hell. 6.5.27-32). A Theban garrison was established for several years at the harbour in Gytheion. The warship represented in the lower relief panel is not the Argo (as suggested by Vermeule), but a warship [cf. infra no 103].

89) D. KNOEPFLER, “Amarynthos 2007. Bilan et perspectives”, $A K 51$ (2008), p. 165-171: K. reports the discovery of a small marble fragment during a Swiss excavation west of the hill Paliochora in Amarynthos (near Eretria). Only the letters [--] vv $\theta[--]$ survive, probably part of the place name ( $\varepsilon^{2} \vee A \mu \alpha \varrho u v v \theta \omega$ ? $)$. This discovery favours the identification of this site with the famous Artemision of Amarynthos. A lead weight with the name of Artemis (IG XII 9, 893) has also been found west of the hill.

90) C. KoKKInIA, "The Inscriptions of Boubon: a Catalogue”, in C. KoKKINIA (ed.), Boubon: The Inscriptions and Archaeological Remains. A Survey 2004-2006, Athens, 2008 [BE 2009, 470]: K. presents a catalogue of 102 inscriptions found in Boubon and its vicinity ( $f$. EBGR 1998, 187). For no 1 see EBGR 2007, 97, where a different restoration of the clause concerning the treatyoath is suggested. Ruler cult: Numerous texts, mostly honorary inscriptions on bases of statues of emperors and members of the imperial family, were found in the Sebasteion (6-22). An

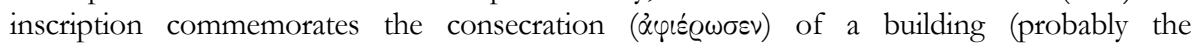
Sebasteion) to Nero through the governor Licinius Mucianus (9). Also a dedication to Drusus (4) is connected with the imperial cult. The civic emperor cult was served by a priest and a

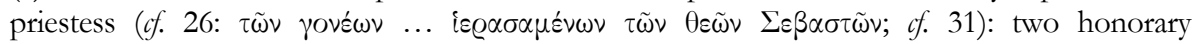

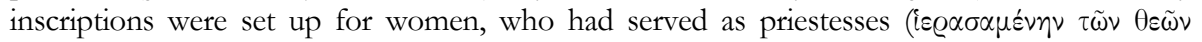
$\left.\sum \varepsilon \beta \alpha \sigma \tau \tilde{\omega} v\right)$ together with their husbands (23: three times; 28). There are indirect references to the provincial emperor cult: three honorary inscriptions mention the fact that the honoured individuals were relatives of Lykiarchai $(24,26,27)$ [on the identity of Lykiarches and high 
priest see EBGR 2006, 42]. A former Lykiarches served as an agonothetes of a local agonistic

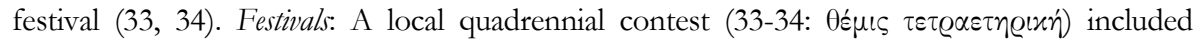
competitions in wrestling (men) and pankration (boys). A former Lykiarches served as agonothetes. The offering of banquets during festivals is mentioned in the honorary

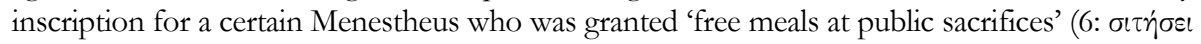

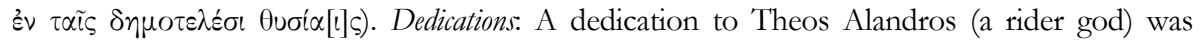
made in fulfilment of a vow (101). A board of agoranomoi dedicated a statue (andrias) to a god, after their term in office, in accordance with the promise they had given (71) [as summa honoraria?]. A similar dedication of agoranomoi (72) suggests that the addressee was Ares (72: Megistos Theos Ares). Funerary cult, afterlife: An epitaph mentions the obligation of a man's

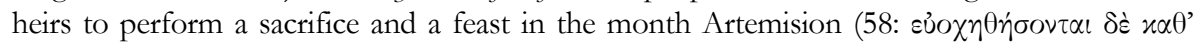

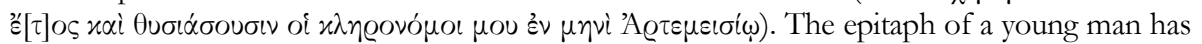
the standard phrase 'it is not bad to die, for this is what destiny has designed, but to die prematurely and earlier than one's parents' $(38=$ GVI $1665=$ MERKELBACH - STAUBER, SGO IV $\left.\mathrm{n}^{\circ} 17 / 2 / 1\right)$. The unique feature of this text is, however, that the standard phrase is presented as the oracular pronouncement of a certain Kerellaios, a chief diviner: Aủe. Eủ $u \chi \chi^{\prime}[-$

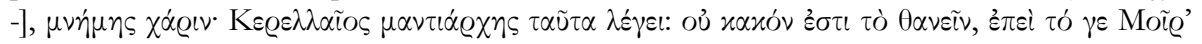

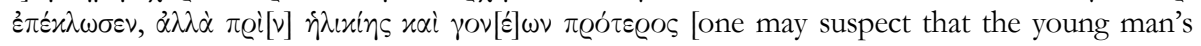
relatives consulted an oracle after his death and received this response]. Another epitaph offers consolation through the stereotypical phrase 'I was, I have been, I am not, I do not care',

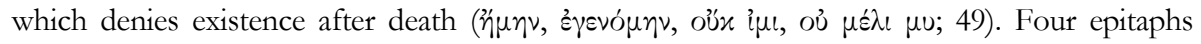
mention the erection of funerary altars ( $\beta \omega \mu$ óc: 66, 80, 84, 93).

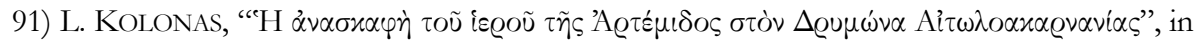

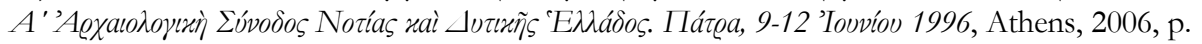
493-498 [SEG LVI 609-6011]: K. presents inscriptions found in a deposit in a sanctuary of Artemis at Drymonas (territory of ancient Alyzia). The base of a dedication was re-used and inscribed with a Hellenistic text that prohibits throwing bones in the sanctuary ( $\mu \dot{\eta} \dot{\alpha} \pi 0 \sigma \tau \varepsilon \dot{\varepsilon \varepsilon \nu}$

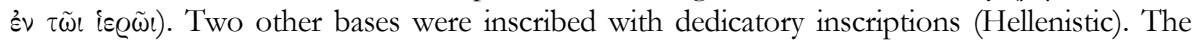
first records a dedication made by a woman to Epikrateia, i.e. Artemis Epikrateia (an unattested epithet). Only the name of Artemis can be recognized in the other.

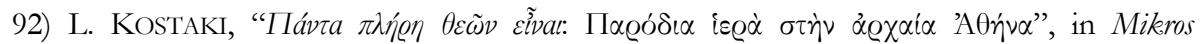
Hieromnemon, p. 145-177 [BE 2009, 152]: K. studies a very interesting and rather neglected aspect of the religious topography of Athens: the existence of small shrines, heroa, sanctuaries, and precincts on streets, incorporated into the urban setting, near houses (e.g. IG $\mathrm{I}^{3} 426$ lines 66-69) and workshops as well as near the city walls (6th-5th cent.). Such sanctuaries are attested through literary sources, inscriptions (especially boundary stones, e.g. SEG XXIV $58+$ XXVI 52), and archaeological finds. They were often under the responsibility of families, phratries, and cult associations. Such sanctuaries include the Melanippeion, Eileithyion, Eurysakeion, Bouzygion, Anakeion, Hyakinthion, the sanctuary of Kodros, Basile, and Neleus, and shrines of Herakles, Zeus Phratrios and Athena Phratria, and Apollon Agyieus.

93) A.V. KovalchuK, “Cherepitsa s imenem Afrodity iz Kep”, in Bosporskë fenomen 2, p. 314316 [BE 2008, 421]: Ed. pr. of six stamped tiles from Kepoi (North Shore of the Black Sea,

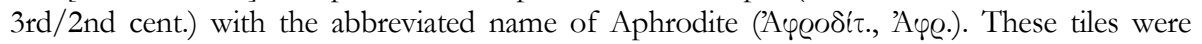
used in a temple of Aphrodite, which may be identified with a building excavated in 1963.

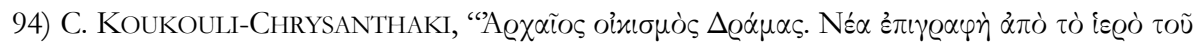

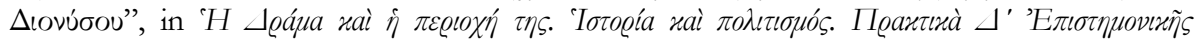

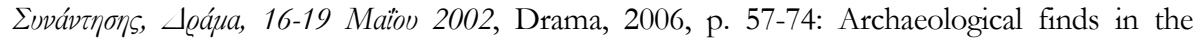
modern town of Drama point to the existence of a sanctuary of Dionysos, in use from the 5 th 
cent. BCE to the Imperial period. Its exact location is not known. An inscription found in

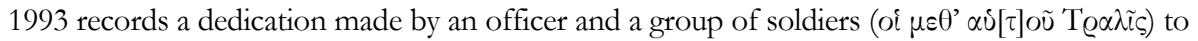

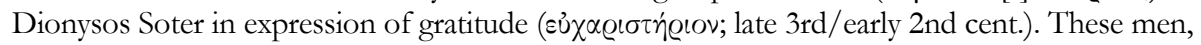
members of the Thracian or Illyrian tribe of the Tralleis, must have made the dedication after a battle.

95) P. KRENTZ, “The Oath of Marathon, not Plataia?”, Hesperia 76 (2007), p. 731-742: A stele at Acharnai, set up by a priest in the 4th cent., contains an oath that has traditionally been interpreted as the oath sworn by the Athenians (and the Greeks) before the battle at Plataiai, 'when they were about to fight against the barbarians' (Lykourgos, 1, 18 and Diod., XI, 29, 3). Pointing to differences between the reports of the literary sources on the oath of Plataiai and the text of the inscription, $\mathrm{K}$. argues that this oath is the one sworn by the Athenians before the battle of Marathon. The explicit mention of Sparta and Plataia, the pledge to bury the dead where they would fall, the reference to 'fellow-fighters' and not to allies, as well as to taxiarchoi instead of lochagoi, and the pledge to destroy only Thebes make better sense in the context of the Battle of Marathon.

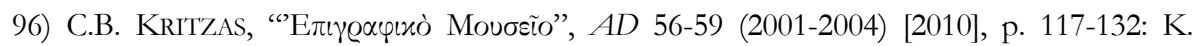
presents the text of a long funerary epigram from Athens (2nd/3rd cent., p. 120). Apollonios, a man who practiced justice and wisdom, followed advise given to him in a dream and by

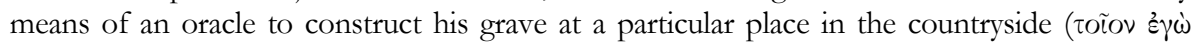

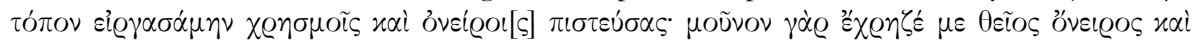

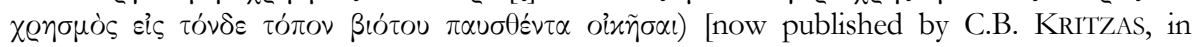

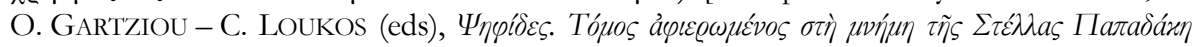

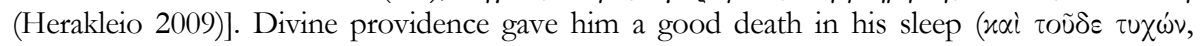

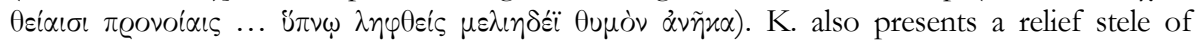
unknown provenance (Megaris or Attika) dedicated by a woman to Ino (3rd cent., p. 123).

97) S.D. LAMBERT, "Aglauros, the Euenoridai and the Autochthon of Atlantis", ZPE 167 (2008), p. 22-26 [BE 2009, 186]: L. discusses a new Athenian decree (see infra no 106) that mentions rites connected with the dressing of a statue (Athens, c. 150). While G. Malouchou attributed this decree to the genos of the Euenoridai, L. favours its attribution to the city of Athens: the fragmentary text refers to rites to be performed by various people, not necessarily all of them by the Euenoridai; the vestment of Athena was a polis matter ( $c$. IG $\mathrm{II}^{2}$

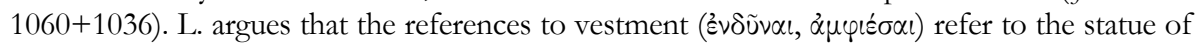
Athena and not to the statue of Aglauros, and that some aspect of the ritual took place in the sanctuary of Aglauros (perhaps during the rite of the Kallynteria). The Euenoridai must have been a traditional Attic genos, named after Euenor, an autochtonous inhabitant of Atlantis (Plato, Kritias 113c-d). In Plato's Atlantis myth, Euenor corresponds to Kekrops and his daughter Kleito, with whom Poseidon begat five pairs of twin sons, to Aglauros. The Euenoridai had some relationship with the Salaminioi, who supplied the polis priestess of Aglauros and Pandrosos, and the Praxiergidai, responsible for the vestment of Athena's statue; the Praxiergidai and the Euenoridai may have been jostling for a position in connection with cults on the Acropolis. If Aglauros was served both by a priestess and a priest, the priest in lines $5 \mathrm{f}$. may be her priest, supplied by the Euenoridai.

98) S.D. LAMBERT, "Polis and Theatre in Lykourgan Athens: the Honorific Decrees", in Mikros Hieromnemon, p. 53-85: A special assembly took place in Athens in the theatre of Dionysos after the City Dionysia in Elaphebolion. L. republishes ten honorific decrees that were passed by this assembly in 332-322 (IG II ${ }^{2} 345+$ add., 346, 347, 351+624, 372+add., 551; SEG XXVI 76-77; XXXV 71; XXXVI 149). Although the subject of the fragmentary decrees 
is not always clear, it seems that all of them honour men, Athenians and foreigners, for their services to the festival (artists, poets, benefactors etc.).

99) V. LAMBRINOUDAKIS, "Interrelations between the Aegean and the Levant during the Late Classical Period: The Case of Two Inscriptions from Naxos", in N.C. STAMPOLIDIS (ed.),

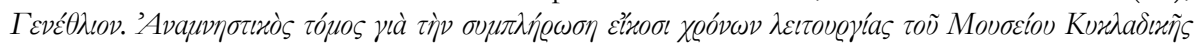
TÉxv but originally from Rheneia (c. 300). A Levantine association ( $\sigma \cup v \theta \imath \alpha \sigma i \tau \alpha l)$ set up the epitaph for one of its members

100) N. LANÉRÈs, "L'éphèbe au serpent de Magoula. Propositions pour la relecture d'une inscription archaïque laconienne", REG 121 (2008), p. 1-16: A fragmentary stele from Lakonia (IG V.1.457, late 6th cent.) with a representation of a young man and a snake is a dedication to the Dioskouroi ([$\Delta \Delta \iota \sigma]$ xó@oı, i.e. dative dual).

101) M.L. LAZZARINI, "Aiòn: eternità e memoria. Due chiodo bronzei iscritti della piana

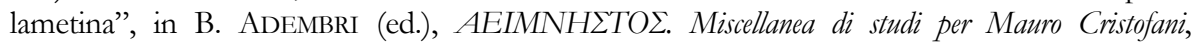
Florence, 2006, p. 150-153 [SEG LVI 1117]: Ed. pr. of two inscribed bronze nails (Lamezia Terme, 4th/3rd cent.). The small nails $(2 \mathrm{~cm})$ were bent; the word $\alpha i \tilde{\omega} v o \varsigma$ was circumscribed around the lower surface of the nailhead. These objects should be distinguished from magic nails attested in the Imperial period. L. interprets them as grave gifts intended to symbolize the permanence of death and associates them with Orphic ideas.

102) N.A. LejPunskaja - A.S. Rusjaeva, "A Private Museum in Olbia of Pontos", Bosporskie issledovanija 11 (2006), p. 108-126 (in Russian) [BE 2009, 368; SEG LVI 905-907]: Ed. pr. of three vases with graffiti and a statue of an enthroned Muse found together in a monumental house with an altar, located in the northern part of the lower town of Olbia (4th/3rd cent.). As can be inferred from these graffiti, this building served as a shrine of the Muses. One of the vases is inscribed with the word Mouseion (3). The other two name Apollon, Helios, Plouton, Poseidon, the Muses, Nike, and Theos (1); Mneme, Eros, the Muses, and Polymedon (the dedicant?; 2). [A. AvraM, BE 2009, 368, points out that a Mouseion was founded in the same period in Histria (I.Histriae 1 line 15)].

103) E. MACKIL, “A Boiotian Proxeny Decree and Relief in the Museum of Fine Arts, Boston and Boiotian-Lakonian Relations in the 360s", Chiron 38 (2008), p. 157-194 [BE 2009, 260; SEG LV 564 bis]: M. studies a stele with an honorary decree of the Boiotian Koinon for Timeas [see supra no 88]. She discusses in detail the relief (p. 165-171) and the historical context. According to her interpretation, Timeas was not a perioikos from Therapne but a Spartan, possibly exiled from Sparta. The text may date to the period of the Boiotian shipbuilding program of c. 365-363.

104) I.A. MAKarov, "The Bosporos, Thrace and Tauric Chersonesos in the First Quarter of the 1st Cent. CE”, VDI 263 (2007.4), p. $62-69$ (in Russian) [BE 2008, 410]: Ed. pr. of a dedication from Chersonesos in Tauris on behalf of the Thracian king Kotys VIII to gods designated as theoi epekooi (12-19 CE). The dedication is likely connected with the marriage of the Bosporan king Aspourgos (of whom the city was then a protectorate) to Gepaipyris, probably a sister of Kotys VIII.

105) C.G. MALACRINO, "Il santuario di Eracle Kallinikos epi limeni e lo sviluppo del porto di Cos in età ellenistica”, NAC 35 (2006), p. 181-219 [BE 2007, 25; SEG LVI 982]: The author studies the architectural development of the harbour area, focusing on the sanctuary of Herakles. A sanctuary of Aphrodite Pandemos and Pontia had been previously founded here, probably in connection with the synoikismos of 366. The construction of a new fortification wall in the late 4th cent. allowed space for the foundation of a temenos of Herakles near the sanctuary of 
Aphrodite. The earliest attestation of this cult is a sacrificial calendar (PH 39; Iscr.Cos ED 140;

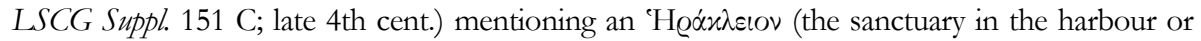
the sanctuary founded by Diomedon?) and a second sanctuary of Herakles at Ko[ví $\alpha \lambda \lambda]$ ov. In the 3rd cent. part of a stoa served as a propylon of the sanctuary. After the earthquake of 198 (Iscr.Cos ED 178), reconstruction in this area resulted in its monumentalization. The sale of the priesthood of Herakles Kallinikos (Iscr.Cos ED 238) is attested in the early 2nd cent. In the late 2nd cent. there is evidence for two sanctuaries of Herakles Kallinikos, one in the agora (z $\pi i$

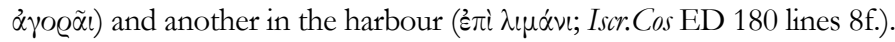

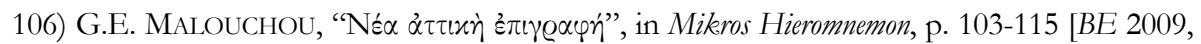
185]: Ed. pr. of a fragmentary decree from Athens (mid-2nd cent.). The text concerns ritual

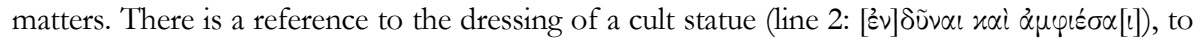
the sanctuary of Aglauros (line 3), the hitherto unattested genos of the Euenoridai (line 4), a prayer (line 3: $x \alpha \tau \varepsilon[0 \chi-?])$, a priest and sacrifices on behalf of the council, the people, and the land's produce (lines 4-6), and to Hestia (line 8). M. suggests that all these rites were performed in the area of the Aglaureion [see the comments of S.D. LAMBERT, supra no 97].

107) F. MALtomini, "Due nuovi testi di magia rurale”, ZPE 164 (2004), p. 159-183 [BE 2009, 489]: Ed. pr. of two lead tablets from Asia Minor (Bithynia?, now in a private collection) with an invocation of the Christian god to drive away disease from humans and harmful insects from the fields. The first text applies 'analogical magic'. Just as the ocean and the springs have water, the sun chariots, the heaven stars, and the moon waves, so should the owner's vineyards

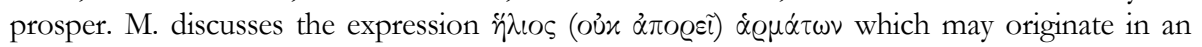
older pagan magical text. The second text is fragmentary. In an appendix M. presents a very useful list of 20 magical texts that promote the fecundity of the fields.

108) G. MAnganaro, "Doveri dello stratego nella Kyme eolica, a regime democratico, nel III sec. a.C.”, EA 37 (2004), p. 63-68 [SEG LIV 1229; BE 2005, 396]: Ed. pr. of a fragmentary inscription from Kyme (3rd cent.) concerning the office of the strategoi and the protection of

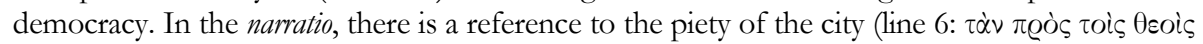
$\varepsilon \dot{v} \sigma \varepsilon \varepsilon \varepsilon(\alpha \nu)$. The freedom of the city is attributed to divine protection (lines 9-10: $\sigma[0] \nu \alpha \nu \tau \iota-$

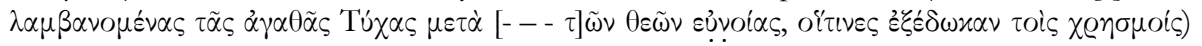
[for an improved restoration see supra $\mathrm{n}^{\circ} 65$ ].

109) C. MAREK, Die Inschriften von Kaunos, Munich, 2006: M. presents a corpus of the inscriptions of Kaunos, which also includes a collection of the literary and epigraphic testimonia for this city, and a study of its topography, history, and institutions. Many texts are of religious interest. New texts are marked with an asterisk. We single out several significant inscriptions. A

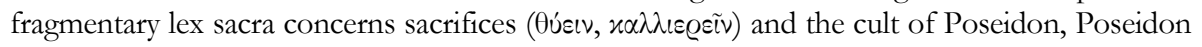
Asphaleios, Themis, Artemis, Apollon $(31=L S A M$ 87, late Hellenistic or early Imperial period). A decree of the synodos of the Euxineis, probably a village (33, Hellenistic), aimed at

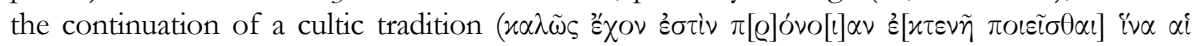

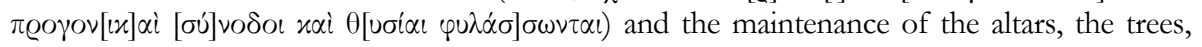
and a hut ( $\left.x \alpha \lambda \cup \beta \beta_{\varsigma}\right)$. The responsibility was assigned to the bierokeryx (for the altar), the dikastai, i.e. probably the magistrates of the village (for the hut), and volunteers (for planting of trees and for taking care of trees for five years). Upon successful fulfilment of this service, these individuals were to be crowned during the annual gathering at the festival Katasporia (a fertility festival). Individuals were encouraged to donate money, from 30 to more than 500 drachmai; the larger the amount the greater the honour. The honours started with the annual crowing of the sponsor at the Katasporia; a larger amount added a golden band to the crown; an even larger amount made this honour hereditary, and the donor was annually honoured during two festivals (the Katasoria and another festival); finally, for a still larger amount the annual heredi- 
tary crowning at the two festivals was supplemented with double portions of the sacrificial meat. A dossier of documents concerns the participation of Kaunos in the mysteries of Samothrace $(* 28,1$ st cent. CE). The dossier consists of a fragmentary honorary decree of Samothrace (one recognizes the word $\theta \varepsilon \omega$ gi $^{\alpha}$ ) and a decree of Kaunos concerning the election of hieragogoi, who were to lead a group of young men to a pilgrimage to Samothrace. One of the best known documents of Kaunos is an endowment aiming at relieving traders from customs and taxes (35, c. 117-138); inter alia the traders were freed from a donation to

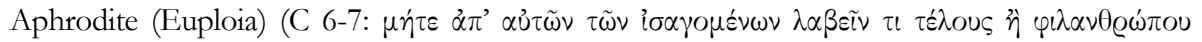

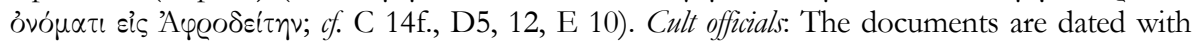
reference to the eponymous priest $(* 4, * 6,19,28, * 37,39, * 40, * 41,56)$. Other cult officials: priests of Nike and Zeus Olympios (*73), Dea Roma (*92,*96), Zeus Polieus and Leto $\tau \tilde{n}$

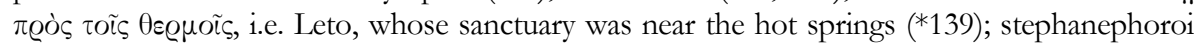
of the god Basileus $(36, * 139,142)$. The hieragogoi were responsible for leading pilgrims to the sanctuary of Samothrace $(* 28 ; * 8)$. Sanctuaries: Official documents were published in the sanctuary of Apollon (*10, 20,*34), which served also as a bank (*34 lines 10f.). An inscription commemorates the foundation of a sanctuary of Zeus Xenios and Meter (75, Hellenistic?:

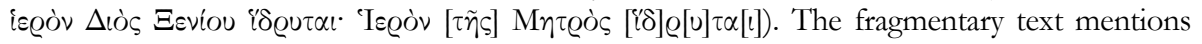
thiasitai and a dream $\left([x] \alpha \theta^{\prime}\right.$ ó $\left.\varrho \mu \alpha\right)$. Dedications: Several dedications were made to the Egyptian gods, often upon divine command: to Isis ( $* 66$, Hellenistic; $x \alpha \tau \dot{\alpha} \pi \varrho o ́ \sigma \tau \alpha \gamma \mu \alpha)$; Sarapis, Isis, and the Theoi Adelphoi, i.e. Ptolemy II and Arsinoe (*67; $x \alpha \tau \dot{\alpha} \pi \varrho o ́ \sigma \tau \alpha \gamma \mu \alpha)$; Sarapis $(* 68,69, * 70)$, Sarapis and Isis by former priests $(* 71, * 72: \chi \alpha \varrho \iota \tau \dot{\eta} \varrho \iota v)$. In three cases the dedicants were former priests (*70-*72; the priest in $\mathrm{n}^{\circ} 72$ is that of Sarapis). Other dedications are addressed to the god, i.e. Basileus (*45, 5th/4th cent.); Zeus Xenios (*74); an anonymous god (*79); to the gods $(55,58, * 59, * 73)$. Dedications were made by magistrates (58), the winner in an equestrian contest at the Delia (61) and at the Nemea (63), and a tragic poet who won a victory at the pentaeteric festival for Leto and Dea Roma (62). The dedicated objects include a baetyl $(* 80)$. Honorific statues were dedicated to the gods (46-53, *92): of the Hekatomnids (46-48); of members of the family of Protogenes (49-53, early 3rd cent.; 49: $\pi \tilde{\alpha} \sigma \iota \dot{\alpha} \theta \alpha \nu \alpha \dot{\tau} \tau o \iota$; 50: Oj̉e $\alpha v i \delta \alpha(\varsigma)$. Inscribed altars attest the cults of Apollon (57), Ge (*78), Zeus Soter (*76), Zeus Hedraios and Ge (*77, Imperial period; Zeus Hedraios is known in Patara). Ruler cult. An altar attests the cult of Arsinoe Philadelphos (54); Ptolemy II and Arsinoe were also worshipped together with the Egyptian gods (*67). The imperial cult is indirectly attested through references to the high priest of the imperial cult $(35, * 140)$ as well as to priests and priestesses of the Augusti (*140bis, 141, 142,*143); there is also a reference to the high priests of the Lykians $(* 137)$. In one case $(* 140 \mathrm{bis})$ it is stated that a woman served as priestess of the

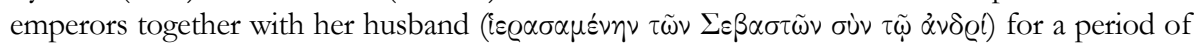
four years $(\varkappa \alpha \tau \dot{\alpha} \pi \varepsilon v \tau \alpha \varepsilon \tau \eta \varrho i \delta \alpha)$. Festivals and contests. The local benefactor Agreophon served as

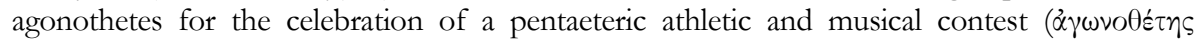
$\gamma \varepsilon v o ́ \mu \varepsilon v o \varsigma$ हैv $\left.\pi \varepsilon v \tau \alpha \varepsilon \tau \eta i^{\prime} \delta \iota ; 30\right)$. An individual made an endowment for the organisation of a musical agon $(* 34,111 \mathrm{CE})$. An inscription contains a list of victors in musical festivals; only the name of the (local) Ptolemaia can be recognized (*37, Hellenistic). Honours for Kaunian judges sent to Smyrna were to be announced at the Dionysia in Smyrna (17-18) and the mousikos agon in Kaunos (19, Hellenistic); two inscriptions attest the honour of prohedria during contests $(* 90, * 102)$. Divination: The Kaunians sent Menodoros of Imbros to the oracle of Apollon in Grynos to receive instructions concerning the propitiation of the gods in order to

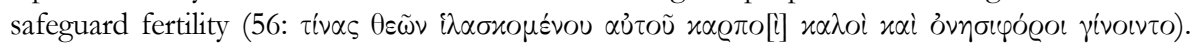
The oracle recommended the worship of Apollo and Zeus Patroios (Hellenistic). Associations:

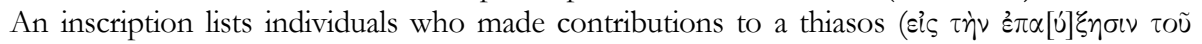
$\theta_{\iota}[\alpha \sigma o u] ; 39$, Hellenistic). Myths: Two tribes were named after mythical figures: Kranaos $>$ Kranais and Rhadamanthys $>$ Rhadamanthis $(64, * 65)$. Funerary cult: A long decree concerns the 
public funeral of Agreophon, a local benefactor, and his burial in the gymnasium (30, late 1st cent. CE).

110) G. Marginesu, Gortina di Creta. Prospettive epigrafiche per lo studio della forma urbana, Athens, 2005 [BE 2007, 28; SEG LV 989]: M. summarizes the archaeological and textual evidence for the early history of Gortyn and discusses in detail the inscriptions, which provide information concerning the formation and development of the polis, its topography, the organization of public space, including the sanctuary of Apollon Pythios (Пúfıv). Inscriptions of religious significance include a regulation concerning funerals (I.Cret. IV 46; p. 68f.) and a document concerning the establishment of freedmen in a location (Latosion) named after Leto (I.Cret. IV 78; p. 70-74). In an appendix, M. republishes with an Italian translation the most important texts, on which his study is based.

111) M. MARI, "The Ruler Cult in Amphipolis and in the Strymon Valley", in Thrace in the Graeco-Roman World, p. 371-386: M. discusses the evidence for ruler cults in Macedonia, Thrace, and Thasos (on p. 385, there is a list of the relevant epigraphic testimonia). M. argues that Philip II received a cult in Amphipolis already in his lifetime. The identity of a King Philip, who according to several inscriptions was recipient of a cult, is debatable (Philip II or Philip V). Observing that the epithet soter was usually attributed to a living king for recent services and taking into consideration the letterforms of the relevant inscriptions, M. suggests that Antigonos Soter in Oreskeia (SEG XLVIII 812) probably is Antigonos Doson rather than Gonatas; the Philippos Soter in inscriptions from Maroneia (I.Thrac.Aeg. E186), Nikiti (SEG L 606), and Thasos (Recherches -- Thasos II no 405) is Philip V.

112) N. Markov - Z. Velichkov, "Late Antique Bone Amulet from Serdica", Archaeologia Bulgarica 11 (2007.2), p. 45-49 [BE 2008, 97]: Ed. pr. of a bone amulet found in the theatre of

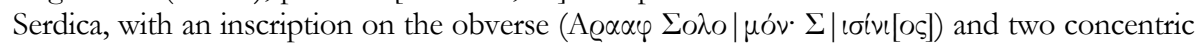
circles (a pair of eyes?) on the reverse.

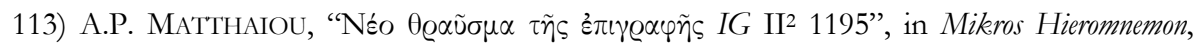
p. 87-102: Ed. pr. of a small fragment of a demotic decree (Athens). M. shows that it is part of a stele with the last lines of an Athenian decree and a decree of the deme of Kollytos (LSCG $38=$ IG II2 $1195+620+$ SEG XLIV 42; cf. EBGR 1993/94, 241 and 268), of which M. presents a new critical edition. Contrary to what was hitherto thought, the demotic decree is not a cult regulation and does not concern a sacrifice to Agathe Tyche (the invocation $\alpha \gamma \alpha \theta \tilde{n}$ $\tau u ́ x \eta$ was misunderstood). Eukadmides proposed to vow to the gods and heroes a procession and a sacrifice if the undertaking of the deme would come to a good end; he also proposed to offer a bloodless sacrifice ( $\pi$ ó $\pi \alpha \nu \alpha, \pi \varepsilon \lambda \alpha \nu$ ć) to the gods and heroes annually, starting with the year after the archonship of Hegemon (327/6). The subject of the decree is not very clear; the demotai were asked to offer loans, possibly in order to face a shortage of grain.

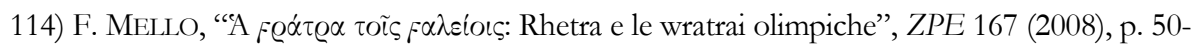

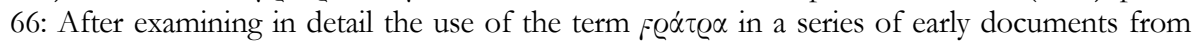
Olympia (IvO 2, 7, 9, 16; SEG XLII 373) and in [later] literary sources, M. argues that the term designates oracular responses and not agreements.

115) L. MigeotTe, "Téménè dèmosia", in P. Brillet-Dubois - E. Parmentier (eds),

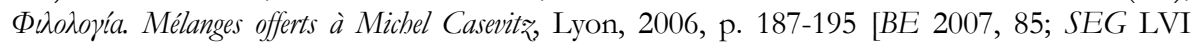
2125]: Collection and discussion of inscriptions that record donations by individuals jointly to

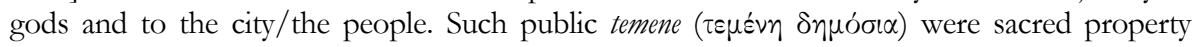
managed by the city.

116) E. Miranda, "Iscrizioni dalla Caria nel Museo di Denizli-Pamukkale”, PP 60 (2005), p. 379-391 [SEG LV 1410-1411]: Ed. pr. of the following inscriptions from Attouda (Imperial 
period): 1) An epigram in honour of an athlete who won a victory at the local Pythia ( $\sigma \tau \varepsilon \dot{\varphi} \rho \mu \alpha$ l Пoi $\theta \imath^{\prime}$ ध $\mu \tilde{\eta} \varsigma \pi[\alpha] \tau \varrho^{\prime} \delta o \varsigma ;$ p. 388f.); 2) an honorific inscription for a victor in the pankration in an agonistic festival (389f.).

117) S. Mitcheld, "The Treaty between Rome and Lycia of 46 BC (MS 2070)", in R. PINTAUdI (ed.), Papyri Graecae Schoyen, Florence, 2005, p. 165-258 [BE 2006, 143; SEG LV 1452]. Ed. pr.

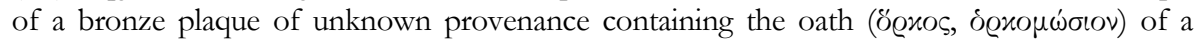

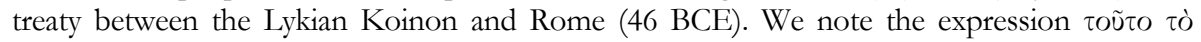

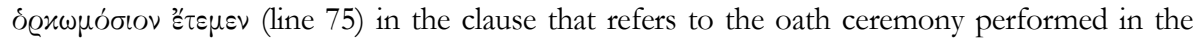
presence of representatives of the two parties; the Roman representatives were probably fetiales.

118) A. Moreno, "Hieron: The Ancient Sanctuary at the Mouth of the Black Sea", Hesperia 77 (2008), p. 655-709: M. gives an overview of the history and topography of the sanctuary at Hieron (entrance of the Black Sea) and collects the relevant testimonia. They include a regulation concerning the sale of the priesthood of the Twelve Gods (I3 $=$ I.Kalchedon $13=$ LSAM 2, 3rd cent.); a dedication made by the crew of a Koan warship (I5 = I.Kalchedon 15, 82 $\mathrm{BCE}$ ); and a dedication to Zeus Ourios (I6 = I.Kalchedon 14).

119) I.S. MOYER, "Notes on Re-reading the Delian Aretalogy of Sarapis (IG IX.4 1299)", ZPE 166 (2008), p. 101-107 [BE 2009, 396]: On the basis of letterforms, M. dates the Delian aretalogy of Sarapis (IG XI.4.1299) to the late 3rd or early 2nd cent. and makes minor editorial suggestions. As regards lines 43-46, M. modifies Wilamowitz's conjecture and reads $\alpha \nu \tau \imath-$

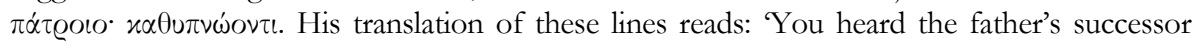
praying at night to put a brazen image in the temple, and to finish it well: for having appeared to him as he slept in his bed, you ordered him to fulfil his obligation.' One of the major themes of this poem is the hereditary succession of the priests of the Sarapieion.

120) T.H. NiELSEN, "A Note on the Bronze Bull of Aleatis from Nemea (= SEG 11, 292)", ZPE 167 (2008), p. 73-74 [BE 2009, 228]. A bronze votive bull dedicated in Nemea (SEG XI

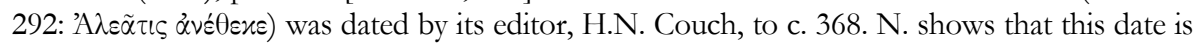
based on the misinterpretation of the personal name Aleatis as an ethnic, and the erroneous view that Alea was affected by the synoecism of Megalopolis in 368 (Paus. VIII, 27, 3, where the name Alea has been corrected to Asea). Consequently, there is no evidence for cult activity in Nemea between the destruction by fire in c. 415 and the rebuilding around 330.

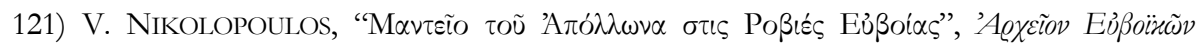

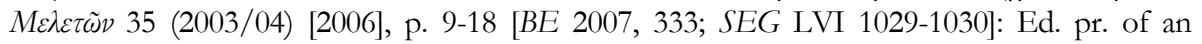
important inscription (2nd/1st cent.) found at Rovies, in the territory of Histiaia (Euboia), at the site of a sanctuary of Apollon. It is the first manumission in the form of a dedication of a slave to a deity from Euboia. A man dedicated a female slave to Apollon Selinaios, obliging her to

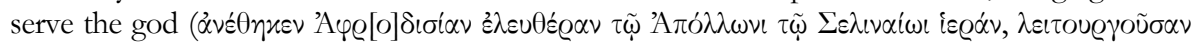

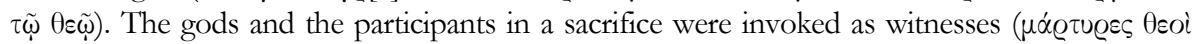
x $\alpha i \theta \tilde{u}[\tau \alpha l])$. N. identifies the site as the oracle of Apollo Selinountios, mentioned by Strabo (X, 1, 3). The epithet of the god derives from oénıvov (celery), not Selinous, and might indicate a possible chthonic character for this cult. Another small fragment mentions a priestess.

122) J. NOLLÉ, "Die Inscriften”, in D. BERGES, Knidos. Beiträge zur Geschichte der archaischen Stadt, Mainz, 2006, p. 60-62: N. presents eight inscriptions found in the sanctuary of Apollon Karneios at Emecik (Old Knidos). In two of them, on a terracotta statuette (1, 7th/ 6th cent.) and on a dish (2), the verb $\alpha v^{\prime} \theta \eta \chi \varepsilon$ is preserved. The most important find is a fragmentary cult regulation $(5$, c. $150-100)$ prescribing the payment of dues $(\dot{\alpha} \pi \alpha \varrho \chi \alpha i)$ by those who offered sacrifices. The amount depended on the victim: half an obol for most victims, one obol for a

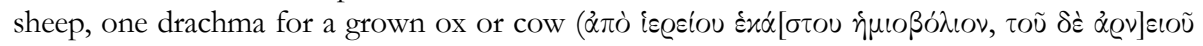




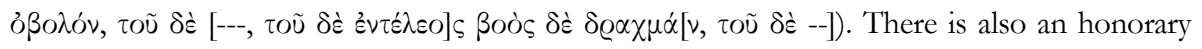
inscription for C. Iulius Theopompos $(7=$ I.Knidos 701) and a list of contributors (8, Imperial period). For a dedication by a prophetes (6) see EBGR 2000, 14.

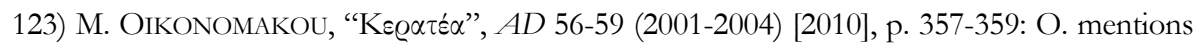
the discovery of a kantharos with a graffito on its base (Keratea, near Athens, 4th cent.) [I read BAXXHON $=$ B $\alpha x \chi \tilde{E} \tilde{O}$ ] $]$.

124) M. OlLER GUZMÁN, "Quelques remarques à propos de deux nouvelles dédicaces à Thétis et Achille trouvées à Apollonia d'Illyrie”, ZPE 167 (2008), p. 75-80 [BE 2009, 291]: The author discusses two dedications to Achilles and Thetis from Apollonia (EBGR 2007, 24). He points out that the joint cult of Achilles and Thetis is rare (I.Erythrai 201 and IOSPE I2 142). She rejects the possibility that the two dedicants were mother and son. The hitherto unattested

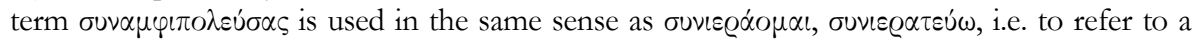
woman who was associated with the priesthood of a man, usually their husband or another male relative. Adducing evidence for the cult of Thetis in Leukas (IG IX $\left.{ }^{2} 1,1238\right)$, of the Nereids in Korkyra (Schol. Apoll. Argon., 1217-1219) and in Corinth (Paus., II, 1, 7-8), and of Amphitrite at Penteskouphia (IG IV 210-300), O. suspects that the cult of the Nereids and Thetis, associated with that of Achilles, originates in Corinth and was transferred from there to the Corinthian colonies.

125) I.A. PApangelos, "H $\sum \dot{\alpha} \varrho \tau \eta ~ \tau \tilde{\eta} \varsigma ~ \sum \imath \theta \omega v i \alpha \varsigma ”$, in Ancient Macedonia VII, p. 715-726 [BE 2008, 341]: Ed. pr. of a dedication by two magistrates (Sarte, Chalkidike, late 6th cent.).

126) N. Papazarkadas - P. Thonemann, “Athens and Kydonia: Agora I 7602”, Hesperia 77 (2008), p. 73-88: P.-T. republish a fragmentary Athenian decree concerning the relations between Athens and Kydonia (SEG LIII 140, late 3rd cent.). The decree refers to the kinship between the two cities, which P.-T. attribute to the mythical traditions according to which both Ion and Kydon, the eponymous heroes of the Ionians and Kydonia respectively, were regarded as sons of Apollon.

127) R. PARKer, "A Festival that Moved, and Other Problems Relating to Skirophorion", in Mikros Hieromnemon, p. 35-39: According to Lysias 26 (382 BCE), the sacrifice to Zeus Soter was offered on the last day of the Athenian year, the 30 Skirophorion; on that day a court could not be summoned. And yet, inscriptions attest more meetings of the assembly for 30 Skirophorion (after c. 350) than for any other day of the Athenian year. One cannot assume that this was a small-scale sacrifice that did not prevent meetings of the assembly, since the 'skin sale records' (IG II 1496 lines 88f. and 118) reveal the very large scale of the sacrifice to Zeus Soter. It is more probable that the date of the sacrifice moved, as the cult of Zeus Soter developed in the 4th cent. In IG II 1496 line 120 P. suggests the restoration [है ${ }^{2}$ Avaxi] $\omega \nu$ [on this festivals cf. EBGR 2007, 62].

128) A. Patay-Horvath, “A Laconian Bronze Disc from Olympia”, Peloponnesiaka 27 (2006), p. 283-302 [BE 2009, 231]: Ed. pr. of an inscribed bronze disc from Olympia (6th cent.), made by Hermesios the Lacedaimonian and dedicated by the Aiginetans [see infra $\mathrm{n}^{\circ} 129$ ].

129) A. Patay-Horvath, "Eine beschriftete Bronzescheibe aus Olympia", Tyche 22 (2007), p. 123-140 [BE 2009, 231]: P.-H. interprets the bronze disc found in Olympia [see supra no 128] as belonging to the statue of an athlete.

130) N.A. Pavlichenko, “A New Inscription from Hermonassa", in Bosporskï fenomen 2, p. 304-306 [BE 2008, 420]: Ed. pr. of a dedication made to Apollon for the well-being of King Pharnakes II (Hermonassa, c. 63-47). The dedication was made by Ma, 'priestess of the 
goddess', in fulfilment of a vow. 'The goddess' [sc. Ma] is mentioned in some inscriptions in Bosporos (e.g. CIRB 976 and 1005).

131) F. Persolja, "L'espansionismo selinuntino di VI secolo alle luce delle testimonianze epigrafiche e letterarie", ZPE 167 (2008), p. 113-118: A cippus marking a sanctuary of Herakles, set up by Aristylos at Monte Castellazzo di Poggioreale (M. GuARDUCCI, "Nuove note di epigrafia siceliota arcaica", $A S A A$ 27-28 [1959-60], p. 272-275) should be seen as evidence for the territorial expansion of Archaic Selinous.

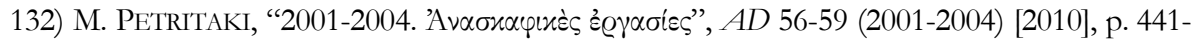
457: A fragmentary dedication to Asklepios was found together with fragments of statues of boys and girls in Piraeus, near the Asklepieion (4th cent., p. 445).

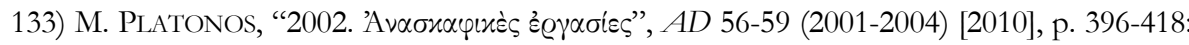
P. mentions the discovery of a fragmentary inscription in the area of two rural sanctuaries in Acharnai (p. 405, 4th cent.). The text records the fact that a certain Dionysios crowned an individual in accordance with a decree of the demos; the honoured man had planted trees in a

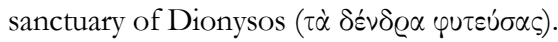

134) I. PolinskaYA, "On the Aiginetan Cult of Zeus Pasios. A New Edition of SEG XI 2", in Mikros Hieromnemon, p. 211-227: P. republishes an inscribed architectural block from Aigina (SEG XI 2, 5th cent.), which names Zeus Pasios. The use of the verb $\pi \varepsilon \delta \alpha \varphi \varepsilon ́ g \varepsilon v$ (i.e. $\mu \varepsilon \tau \alpha \varphi \varepsilon^{\prime} \varrho \varepsilon(\nu)$, probably in the context of a prohibition, suggests that this text was a regulation forbidding the removal or transportation of an object.

135) C. PRÊTRE, “'Erreurs' de graphie involontaires et volontaires dans les inventaires déliens : de la création d'hapax à l'usurpation d'identité", Tekmeria 8 (2003-04), p. 85-101 [BE 2007, 417; SEG LV 891]: Based on a study of unique and rare terms in the Delian inventories, P. argues that the administrators aimed at displaying the sanctuary's reputation by using foreign words

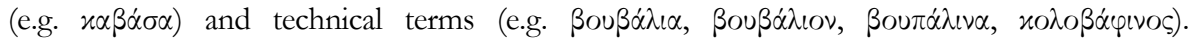

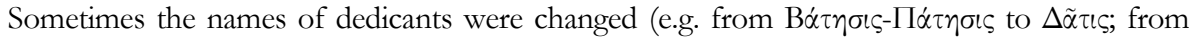
'A $\mu \varepsilon เ v(\dot{v} \delta \alpha \varsigma$ to 'E $\pi \alpha \mu \varepsilon i v \dot{\omega} v \delta \alpha \varsigma)$ in order to increase the sanctuary's glory through reference to famous dedicants.

136) A.D. RIZAKIS, Achaïe III. Les cités achéennes: épigraphie et histoire, Athens, 2008 [BE 2009, 229]: R. presents an overview of the history and institutions of the cities of Achaia and (re)publishes the inscriptions of Aigai, Aigeira, Aigion, Donoussa, Dyme, Keryneia, Leontion, Olenos, Pellene, Pharai, Rhypes, Tritaia. Dyme: Leges sacrae: A regulation concerning the festival of Demeter (Damatria) did not allow women to wear expensive gold jewellery, purple clothes, and make-up ( $6=L S C G 33$, 3rd cent.). Cults: Aphetos, Aphrodite, Anyalios, and Artemis were regarded as protectors of Dyme (7, Hellenistic). The funerary epigram for the mythical hero Polystratos, a companion of Herakles, inscribed in the Hellenistic period, is an interesting testimony for heroic cult (22, c. 200). A gymnasiarchos made a dedication to Hermes and Herakles (8, 2nd/1st cent.). A dedication to Stata Mater (9) and Venus Augusta (10) date to the period of the Roman colony. A theokolos dedicated a bronze bowl during his term in office (11, 4th cent; other references to theokoloi: 2, 3, 5). Honorary statues were dedicated to the gods $(12,13,50)$. Public documents were inscribed in the sanctuary of Apollon (1). Sacrilege: A document (2) records the condemnation to death of individuals who stole sacred objects

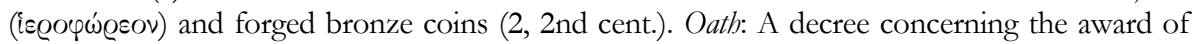

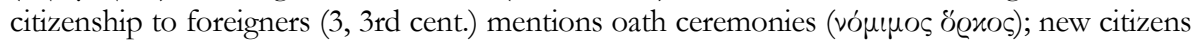
had access to the office of the theokolos. Festivals: Several Latin texts commemorate the magistrates who were responsible for the organisation of ludi (19, 20). Ruler cult. A dedication to Augustus by a libertus (14). 
Pharai: A former gymnasiarchos made a dedications to Hermes and the Dioskouroi (62*, 2nd

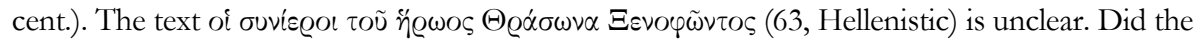
members of an association of hieroi (бuvirgot) dedicate a statue of a deceased member of the association (heros), or were they members of an association of bieroi dedicated to the cult of a heros? A fragmentary Latin text mentions a sacerdos (64).

Rhypes: The dedication to Artemis Faovtia (113, early 5th cent.), patron of the winds (?), was presented in EBGR 2004, 213.

Aigion: A small fragment preserves part of a treaty oath between the Achaian League and

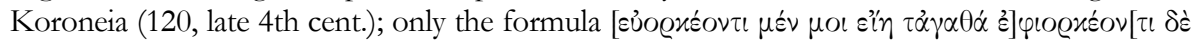
$\tau \dot{\alpha} \nu \alpha \nu \tau i \alpha]$ is preserved. A document concerning the delimitation of territory mentions a sanctuary of Nikeia, i.e. Victory (lines 1, 5, and 6) which was located on the frontier (121, c. 250). Dedications to: Aigeus (122, a bronze jug, c. 450-440); an anonymous deity (123); Isis (124, an incense-burner, as $\delta \tilde{\omega} \varrho o v, 2 \mathrm{nd} / 3 \mathrm{rd}$ cent.). The statue of a victor in a race in the age class of the boys at the Sylleia and the Hemeresia in Lousoi was dedicated to the gods (125, c. 74-79). The Achaian general Kykliadas made a dedication to the gods after a victorious

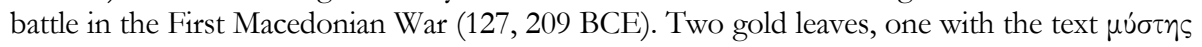
(148, Hellenistic), the other with the names of two mystai (149), have been attributed to the Orphic-Dionysiac mysteries.

Aigeira: A dedication to Asklepios (171) and to an anonymous deity (172). A tile with the stamp biera (183) must have been used in a sacred building.

Donoussa: Four votive pinakes were dedicated to the Nymphs (185, c. 540-500).

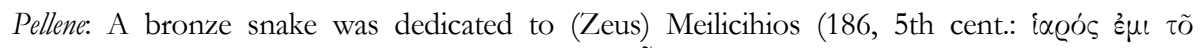

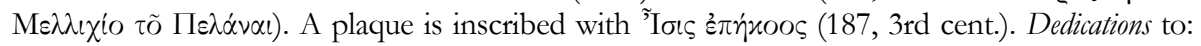

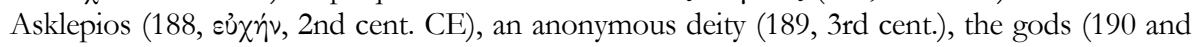
192, honorary statues, 3rd-1st cent.).

137) P. RoEsch †, Les inscriptions de Thespies. Édition électronique mise en forme par G. ARGOUD, A. Schachter et G. VotTÉRO, Lyon, 2007 [revised edition: 2009] [BE 2009, 257]: This electronic corpus of the inscriptions of Thespiai is structured in 12 Fascicules. With its more than 1300 texts, the corpus provides an excellent panorama of religious life in Thespiai. Cult matters: Two decrees mention in the preamble that they concerned a 'sacred matter' ( $\pi \varepsilon \varrho i$ i $\alpha \varrho \tilde{\omega})$. One decree honours judges sent to Delphi (30 line 4), the other concerns the donation of land to the Muses (54 line 29). A fragmentary decree deals with sacred matters, including a sacrifice (43 bis, 3rd/2nd cent.). Dedications: On the dedicatory epigram of Hadrian to Eros (270) see EBGR 2004, 102. Dedications are addressed to Agathos Daimon (220-221); Aphrodite Euekoos (222); Apollon (224-228), Apollon Ptoios (223); Artemis (229-231), Artemis Agrotera (233-234), Artemis Eileithyia (236-248, 250, 251), Artemis Eileithyia and Lochia (249), Artemis Hegemone (235), Artemis Soteira (253), Artemis and Athena (232); Asklepios (254); Athena (255); the Daimones (329); Demeter (256), Demeter Achaia (257), Demeter Prostasia (258), Demeter Eleusinia and Kore (259; cf. 260), Demeter and Herakles (261), Demeter and Hermes (262); Dionysos (263, 344, 369-371); the Dioskouroi (264-266; 265: by a merchant; 266: by a limenarches); Eileithyia (252); Eros (269-271); the Eumenides (272); Helikon (273); Herakles (276, 276 bis, 277, 278-279), Herakles Leuktriades (277 bis), Herakles and Hermes (280); Hermes (281-283 bis, 284); the Homonoia between Thespiai and Athens (331, 2nd cent. CE); Megale Meter (285, *286); the Muses (274, 275?, 287-314, 377, 387, 397; 312, 400-402, 404-

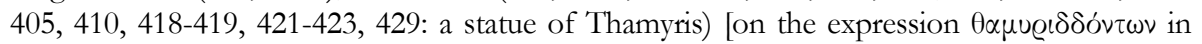
312 see SEG LV 562]; Pan (315); Poseidon (316); Themis (320); Zeus Karaios (323), Zeus Ktesios (324), Zeus Meilichios (325), Zeus Meilichios and Meiliche (326-327) [for such divine dyads (e.g. Pan-Pasa) see EBGR 2006, 97], Zeus Olympios (321); the gods (328); anonymous 
gods (322, 332-340; 322: a group of statuettes of Zeus, Mnemosyne, and Apollon); the Egyptian gods (317-319); heroes: heros Kastorides (267), heros Kolon and Herois (330), Prokles (268). A large group of dedications consists of honorary statues dedicated to the gods, usually by family members (341-343, 345-348, 350-351, 353-354, 358, 367-368, 374, 388, 396, 399, 403, 406, 411-412, 414, 416, 420, 436). Images of individuals were dedicated by their respective fathers or mothers to Artemis Eileithyia (236, 242-252). Other dedicated objects

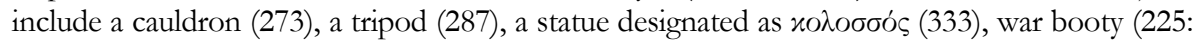
a lance), and an ė $\pi i$ irov@ov (237). Very often dedications were made by cult officials during or immediately after their term in office: a priestess $(240,242,334)$, a priest $(255,325,327,412)$, a former priestess $(227,235,238-239,249,320,335)$, a former priest (232), a former agonothetes (328), a board of hierarchai (329), a bierophantes (260), by magistrates $(266,282)$. A priest of Zeus Aithrios made a dedication to another deity: Athena (255). An epimeletes of the festival Herakleia dedicated a temple to Demeter Eleusinia and Kore from the festival's revenues (259: ¿̇ò $\pi \varrho \circ \sigma o ́ \delta \omega v$; on the connection between Demeter and Herakles $c f .261)$. An agonothetes of the Erotideia dedicated a statue of Eros and the door of the pronaos; he also repaired the sanctuary (269). A freedman and his wife dedicated statues of Isis and Harpokrates, a base, doors, altar, and the barrier of the precinct (319). An important group of dedications consists of statues of Mnemosyne and the Muses accompanied by epigrams describing their properties (289-301, 1st cent. CE). Occasionally, the motive of the dedication is stated: fulfilment of a

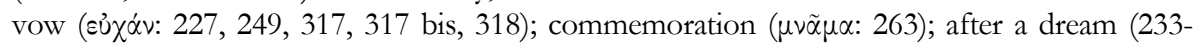

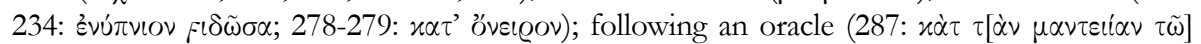

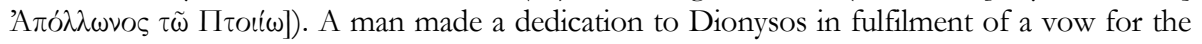

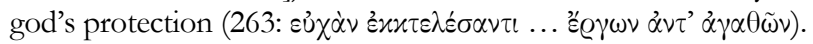

Cult officials: Lists of magistrates and other inscriptions attest numerous cult officials. Priesthoods: priest of Artemis (32), the Muses (156, 161, 165-167, 169-172, 175; cf. 1247), Zeus Aithrios (255), Zeus Meilichios (325), unknown gods (232, 327, 412, 426, 1237); priestess of Charops (354), Demeter (1134, 1338), Demeter Achaia (379), Dionysos (367; cf. 369), Isis (393), unknown gods $(227,235,238-240,242,249,320,334-335,353)$; high priest (374). Other cult officials: aethlothetas of the Muses (84), agonarchos (84, 283), agonothetes (328), agonothetes of the Mouseia (84, 156, 159-161, 165-167, 169-172, 175-178, 180, 184, 358-359, 361, 376, 377, 405), agonothetes of the Erotideia (269, 358-359, 360 bis, 374, 376, 377, 405), epimeletes naon ('supervisor of the temples', 84), epimeletes of the Herakleia (259), bierarches (53-55, 228, 329; responsible for the leasing of public and sacred land: 53-55), bierarches of the Mouseia (175), bieromnemon (84), bierophantes ex Eupatridon (260) [the office reveals an influence from the Eleusinian cult; of. 259: Demeter Eleusinia], grammatistes hieron ('scribe of the sanctuaries', 84), prophetes (223), pyrphoros at the Mouseia (156, 165, 167, 169-172, 176-177, 180, 184), theoros (84),

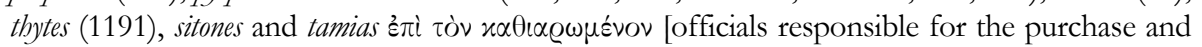
management of grain with sacred money?] (84), tamias of the sanctuary of the Muses (55 line 21: $\tau \alpha \mu i \alpha \varsigma \tau \tilde{\alpha} \nu \mathrm{M} \omega \sigma \alpha \dot{\alpha} \omega \nu)$, tamias hieron (84). The priestesses of Demeter/Demeter Achaia served for life $(379,1138)$. The iteration of an office is attested a few times (for a priestess: 235; for an agonothetes: 405). An honorary inscription for a priestess commemorates the fact that her

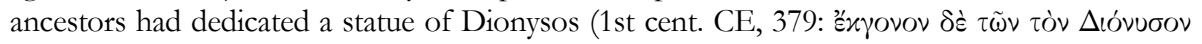
$\dot{\alpha} \nu \alpha \theta \varepsilon \dot{\varepsilon} \tau \omega \nu)$ [her statue was probably dedicated near the statue of Dionysos; for a reference to the dedication of an ancestor see supra $\mathrm{n}^{\circ}$ 1]. A former priest of the Muses endowed 4,200 drachmas for the funding of the sacrifice of a cow during the pentaeteric Mouseia (54). A former priestess was honored by her family for her piety and modesty (354).

Festivals and contests. Numerous inscriptions provide information concerning the organisation of the Mouseia (152-185): a decree concerning the re-organisation of the festival (155); acceptance letters and decrees (152-154, 156-158); accounts (159); lists of victors (161-185); and dedications 
of victors (204-207). The lists and dedications of victors show the transformation of the festival with the addition of new disciplines under the influence of political events (in particular the expansion of Rome) and its connection with the imperial cult. Similar evidence exists for the Erotideia (186-193: lists of victors) and the Pamboiotia (201-203: dedications of victorious teams). Honours were announced at the Mouseia (34) and the Erotideia (34). The Herakleia are attested through a dedication of the epimeletes of the Herakleia (259; $f .215)$. Two other festivals are attested: Panamia and Thoia (215). An honorary epigram commemorates the foundation of an agonistic festival $(362,2 \mathrm{nd} / 3$ rd cent.). A funerary epigram for a young man commemorates

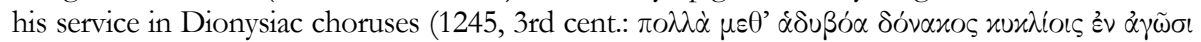

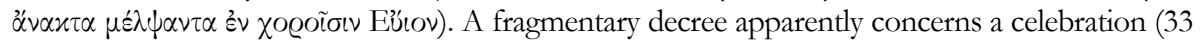

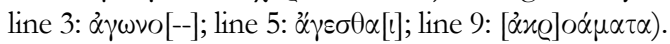

Sanctuaries: Two inventories list sacred property in the Heraion (38, early 4th cent.) and an unknown sanctuary (39). Several documents deal with the leasing of sacred land: land belonging to the sanctuary of Herakles, sacred land (i̊gò có $\mu$ os), a Nymphaion (48, 3rd cent.); land belonging to the Muses (54-55), and to Hermes (54, late 3rd cent.); a Nymphaion (56). Citizens and foreigners (58-61: Philetairos of Pergamon) donated land to the Muses (54-55, 5861), Hermes (61), Agathos Daimon (66-67), and Dionysos (68-71). Money donated by Ptolemy IV was used for the purchase of sacred land of the Muses (62). The leasing document of a garden donated to the Muses stipulates that an area of 100 feet around the sanctuary of Zeus Meilichios [already existing in this garden] should remain uncultivated (55 lines 27f.). Boundary stones marked the land of sanctuaries of Agathos Daimon (66-67), Dionysos (68-71), Theos Tauros, i.e. the deified T. Statilius Taurus (72-80), the Augusti (81), an anonymous deity (63), and a cult association of worshippers of the Muses (65) [see EBGR 2004, 17]. Manumissions

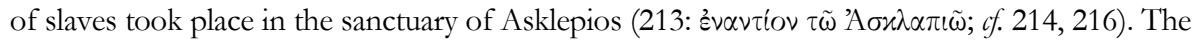
gods guaranteed the freedom $(213,215)$; the manumitted slave took an oath, which invoked Asklepios and promised to fulfill the obligation of paramone, serving their master until his death (213). One of the texts mentions an interesting rite: When the master died, the manumission became effective through a declaration on his grave (214: $\dot{\alpha} \pi[0] \varkappa \alpha \varrho \cup \xi \dot{\alpha} \tau \omega$ ह่ $\pi \dot{\imath} \tau \tilde{\omega} \mu \nu \dot{\alpha} \mu \alpha \tau O \varsigma)$.

Imperial cult. A boundary stone marked the area of the sanctuary of the Augusti (81). Inscriptions connected with the imperial cult include dedications to Hadrian (435), Theoi Sebastoi and their house (426: a porticus and a building somehow associated with the bouleuterion), and the Gens Augusta and Roma (427: a porticus). Cult associations: A decree of an association (synodos) honours a pious ( $\varphi(\lambda o ́ \theta \varepsilon o \varsigma)$ man for his services to the association $(35,1$ st cent.). On an association

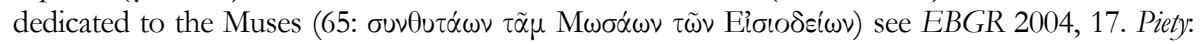
A woman who served as priestess of Isis made a donation for the festival of another god: Dionysos (Imperial period). The grave epigram for Kallityche bitterly complains that the Muses did not listen to the prayers of her father, who was a priest $(1247,2$ nd cent. CE: Moũoal $\delta$ '

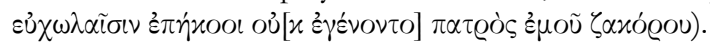

Funerary cult and afterlife: In numerous epitaphs the deceased individual is called heros/ herois (747, 841, 937, 1053-1054, 1151, 1152, 1154-1155, 1157-1169, 1172-1206, 1224-1226, 1233-1236). A manumission record obliged the freedman to crown the grave of his former masters on the

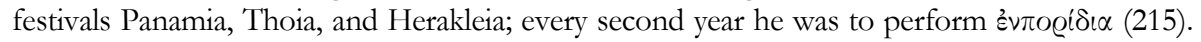

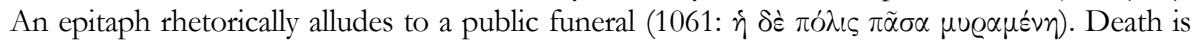

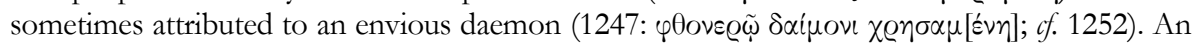
epigram for a man of letters, a certain Herodes [possibly Herodes Atticus; see SEG LV 564], states that he has joined the Muses as the tenth in their rank (1246, 2nd cent. CE: $u \cup x \dot{\eta} \delta^{\prime} \varepsilon^{\prime} v$

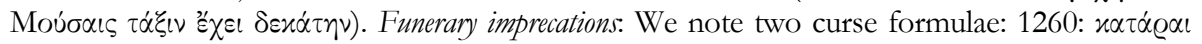

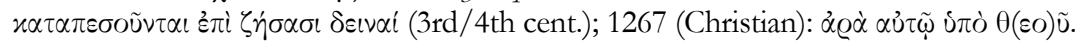


138) M.Ç. ŞAHIN, "New Inscriptions from Stratonikeia and its Territory”, EA 41 (2008), p. 5381 [BE 2009, 459]: Ed. pr. of numerous inscriptions from Stratonikeia and Panamara. Stratonikeia: Dedications are addressed to Zeus Hypsistos (12, 2nd/3rd cent.), Zeus Panamaros

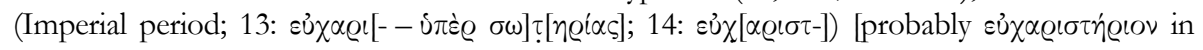

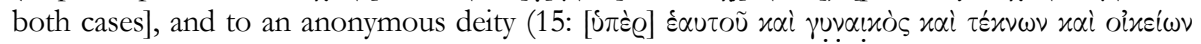

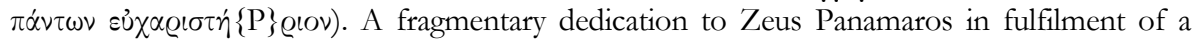

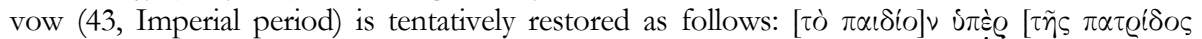

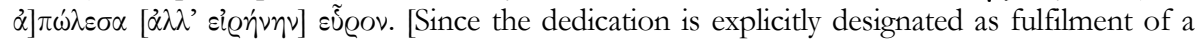

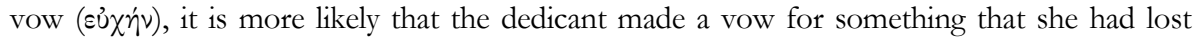

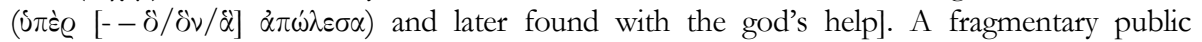
document was to be inscribed in the sanctuary of Zeus Chryasorios (1, early 3rd cent.). A

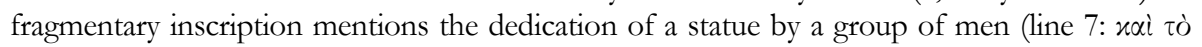

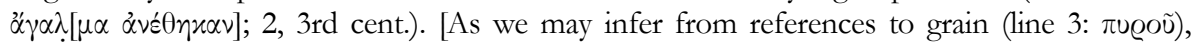
concord (line 3), the seat of the strategoi (line 4: $\sigma \tau \varrho \alpha \tau \dot{\gamma} \gamma(o v)$, and a tower (line 5), the dedicants are somehow connected with a military context: a board of strategoi or (less likely) a group of soldiers]. A board of chreophylakes made a dedication to Zeus (restored) and the people of Stratonikeia (4, c. 150) [possibly the dedication of a structure connected with the chreophylakion]. An inscription honours a priest of Hekate, ė $\pi \varphi \propto \alpha \varepsilon \sigma \tau \dot{\alpha} \tau \eta \theta_{\varepsilon \dot{\alpha}}$ (35, Imperial period). An inscription commemorates gladiatorial combats $(\check{\alpha} \mu \imath \lambda \lambda \alpha \mu$ ovo $\mu \dot{\alpha} \chi \omega \nu)$ that took place under the responsibility of a high priest (45, Imperial period).

Panamara: Several inscriptions (1-12) commemorate priests and priestesses and their services and benefactions. The benefactions consisted of the offering of banquets $(1,6)$, sacrifices (6), and olive oil (8). One priest served $\xi \xi \xi \pi \alpha \nu \gamma \varepsilon \lambda i \alpha \varsigma$ (2), others served during the celebration of

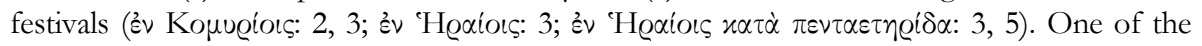
priests served for a second time (3). A text on an altar (12a) seems to contain a prohibition: [- -

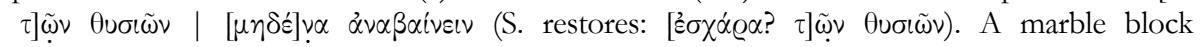
commemorates the dedication of hair by two young men under two different priests (13).

139) M.Ç. ŞAHIN, “Two Lists of Priests from Koraia, a Phyle of Stratonikeia”, EA 41 (2008), p. 82-86 [BE 2009, 459]: Ed. pr. of two blocks decorated with engraved wreaths and successively inscribed with the names of priests. They were found $15 \mathrm{~km}$ east of Stratonikeia. The first list (c. 50-25) begins with the name of an eponymous stephanephoros, which is followed by the name

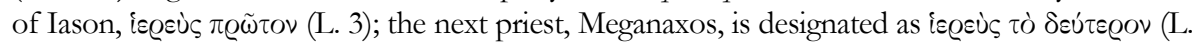
5). Another six names of priests follow. The name of the deity is not given; S. suspects that it was Zeus or another traditional local god. The beginning of the second list is not preserved. It contains the names of 12 priests, sometimes accompanied by the name of the eponymous stephanephoros. Five priests are designated as $K \omega\left(\varrho \alpha \iota \varepsilon^{\prime}\right)$ (Koraia was one of the tribes of Stratonikeia). The ed. assumes that all the priests were from Koraia, the settlement where the

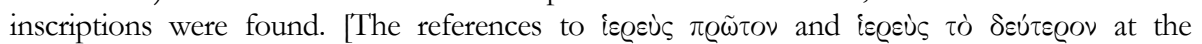
beginning of the first list suggest that these were priests of a newly established cult. The reference to an eponymous stephanephoros shows that these were annual priesthoods.]

140) M.Ç. ŞAHIN, “Number 'Nine' in an Inscription from Aksaray”, EA 41 (2008), p. 86 [BE 2009, 495]: In view of the significance of the number nine in the Hittite myth of Kumarbi certain gods served other gods for nine years -, S. suspects that 'nine' does not have its literal meaning but means 'many'. An epitaph from Yehilova (SEG LII 1464 ter; EBGR 2002, 6; $2005,46)$ states that those who would disregard the owner's will and violate his grave would be punished with the offering of groups of nine animals. Ş. argues that 'nine' here means 'many'.

141) M.H. SAYAR - H. ŞAHIN, “Zeus Kodopas. Eine neue Epiklese des Zeus aus dem Rauhen Kilikien”, EA 41 (2008), p. 113-124 [BE 2009, 500]: Ed. pr. of two dedications found at 
Göztepesi (territory of ancient Korykos in Rough Kilikia). The first dedication was made by

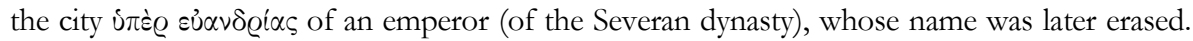
The dedication is addressed to Zeus Kodopaios Epineikios Topaiouchos. The second dedication is made by a man to Zeus Kodopaios in fulfilment of a vow. Zeus Kodopaios was worshipped in the same sanctuary as Zeus Korykios and Hermes Korykios. There is no relation between the epithet Kodopaios and the place names Kodapa in Karia and Kodopa in Lykia. A further dedication to this deity was found $5 \mathrm{~km}$ northwest of Göztepesi. It is addressed to Zeus Kodopas $(\Delta i i$ Koбor $\tilde{\alpha})$. S.-S. suspect that Kodopas is the name of a Luwian god, worshipped in this area and identified with Zeus; the epithet Kodopaios derives from Kodopas. [Since the alpha is written within the pi, I wonder whether we have an abbreviation $(\operatorname{Ko\delta } \delta \pi \alpha(i \omega))$ instead of a variant of the epiklesis. The ending -aios suggests an epithet deriving from a place name - Kodopa, not to be identified with the homonymous Lykian city. If we

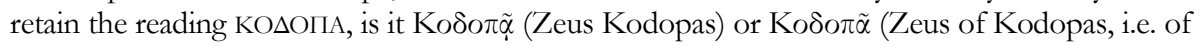
the cult founder)? Names of cult founders in the genitive, following the name of a god, abound; see e.g. EBGR 2000, 108 and 2003, 31.]

142) N. Sharankov, "The Thracian xotvóv: New Epigraphic Evidence", in Thrace in the Graeco-Roman World, p. 518-538 [BE 2009, 337]: S. presents 14 recent epigraphic finds from Philippopolis concerning the Thracian Koinon (mostly inedita); for $\mathrm{n}^{\text {os }} 1,6$ and 11 see EBGR 2005, 143 (1, 3, and 3a). Several texts provide the names of Thrakarchai/high priests of the koinon (1, 6-13; an updated list on p. 532). A Thrakarches served as agonothetes of a pentaeteric agon of the Thracian Koinon (6, 2nd/3rd cent.); it is the first attestation of this agonistic festival. An honorary inscription for Elagabal mentions the neokoreia of Philippopolis (7).

143) H. Siard, "Dédicace d'un mégaron dans le Serapieion C de Délos", BCH 131 (2007), p. 229-233: Ed. pr. of an inscription recording the dedication of a megaron upon divine command ( $\varkappa \alpha \tau \dot{\alpha} \pi \varrho o ́ \sigma \tau \alpha \gamma \mu \alpha)$, found in Serapieion C in Delos (2nd cent.). Neither the location nor the nature of the structure designated as $\mu \varepsilon$ f $\alpha \varrho \circ \nu$ (a subterranean crypt?) nor its relation to the $\mu \dot{y} \gamma \alpha \varrho o v$ mentioned in another dedication (I.Délos 2047, 126/5 BCE) can be determined with certainty.

144) P. SINEUX, "Les récits de rêve dans les sanctuaires guérisseurs du monde grec : des textes sous contrôle", Sociétés et Représenations 23 (Mai 2007), p. 45-65: S. gives an overview of the practice of incubation and the evidence for healing practices in sanctuaries of Asklepios (allusions to medical practices) as reflected by the records of healing miracles in Epidauros, Lebena, and Rome. He focuses on the active participation of priests in the 'editing' of the records of healing miracles; the priests drew information from a variety of sources, including individual dedications and healing reports, and used a variety of media in order to show the god's power and to increase the credibility of the narratives.

145) E. SIRONEN, Inscriptiones Atticae Euclidis anno posteriores. Pars V. Inscriptiones Atticae aetatis quae est inter Herulorum incursionem et imp. Mauricii tempora, Berlin, 2008: The new volume of the Attic corpus contains inscriptions from the late 3 rd to the 6th cent. CE. Many texts were included in $I G I^{2}$ (we mark with an asterisk those inscriptions that were not) and are well-known. The volume primarily contains Christian inscriptions but also numerous texts that contribute to the study of late paganism and the interaction between Christians and pagans. At times, it is not possible to assign a text to a religious group. For instance, the reference to god the father of all

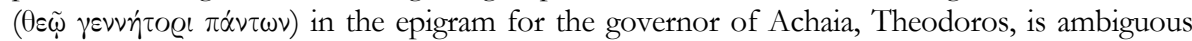
(13276, c. 379-395 CE). Late pagan philosophers: Several texts are related to the activity of the late antique Neoplatonists and other philosophers: Iamblichos (*13277, late 4th cent.), Plutarch (13286, early 5th cent.), Syrianos (*13451), Proclus (*13452), Lachares (13454, late 5th cent.). Late antique paganism: As late as the early 5th cent. an honorand is called 'dear to the immortals' 


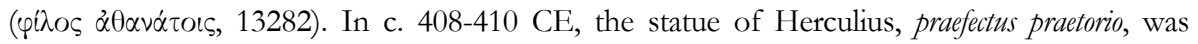

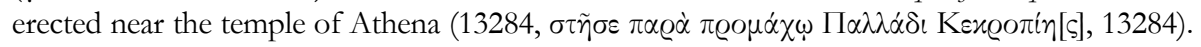
In the same period a fragmentary honorary epigram (for a priest?) refers to Rhea, the sanctuary of Pallas, and the celebration of the Panathenaic festival (?, *13287, 5th cent.). Cult officials: A fragmentary genealogical inscription lists the members of an elite family who occupied offices of the Eleusinian mysteries and other priesthoods (13620, early 4th cent.). An honorary inscription for the historian Dexippos refers to his service as agonothetes of the Great Panathenaia (13262, after 270 CE). Other inscriptions honour a panegyriarches (13273, early 4th cent. CE), and the hierophantes Erotios (13278, 4th cent.). Dedications: In addition to a dedicatory epigram to Pan, by Nikagoras the son of Dadouchos (13251), two dedications commemorate the performance of a taurobolium (13252-13253, 361-387 CE). Building inscriptions after the sack of Athens by the Heruli make allusions to myths and pagan gods (13289: Muses; 13293:

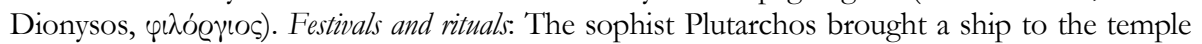
of Athena during the Panathenaia (13281, early 4th cent.). Afterlife: Funerary epigrams for late pagans allude to ideas concerning the afterlife, in particular to the polarity between body and soul and the soul's ascent to heaven (epigram for the Neoplatonic Syrianos, *13451: [ $\psi u \times \dot{\eta}$

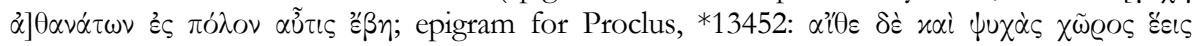

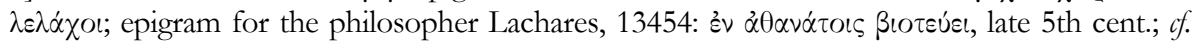
the reference to Rhadamanthys in the epigram for the proconsul Democrates, 13375, 4th/5th cent.). The ed. tentatively regards as Christian two epigrams with ambiguous vocabulary

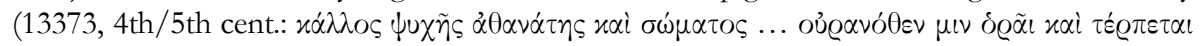

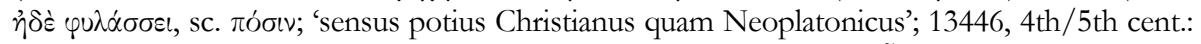

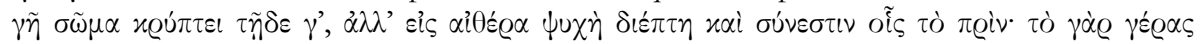

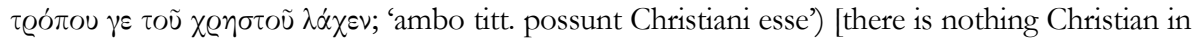
these texts; these are typical motifs in late pagan texts, e.g. in Aphrodisias; see A. CHANIOTIS, "The Conversion of the Temple of Aphrodite at Aphrodisias in Context", in J. HAHN et al. (eds), From Temple to Church: Destruction and Renewal of Local Cultic Topography in Late Antiquity, Leiden, 2007, p. 243-273, note 53].

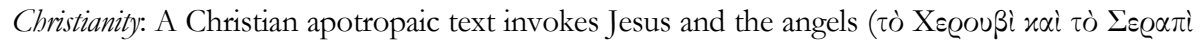

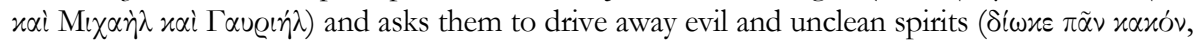

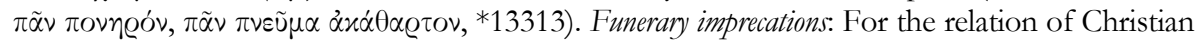
funerary imprecations to their pagan counterparts see supra $\mathrm{n}^{\circ} 13$; several texts from SIRONEN's corpus are included in the collection of BARDANI and PAPADOPOULOS (supra $\left.\mathrm{n}^{\circ} 13\right): I G I^{2} 13517=\mathrm{n}^{\circ} 2747 ; 13519=2848 ; 13523=2681 ; 13540=2869 ; 13571=2817$. The curses for violators of graves are very diverse: e.g. the culprit is cursed to be denied burial

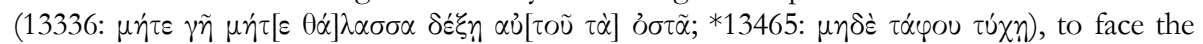

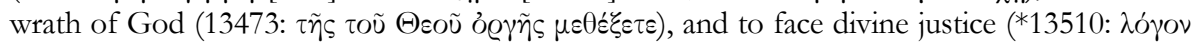

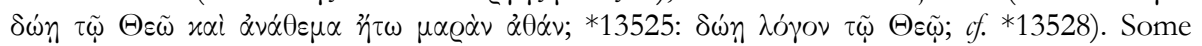

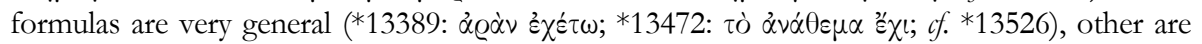
typical Christian, e.g. referring to the punishment of Judas $(* 13365, * 13489)$.

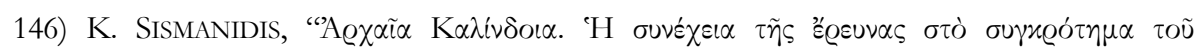

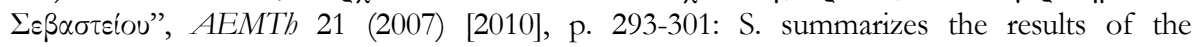
excavation in a building complex at Kalindoia (Macedonia), which has been identified as the Sebasteion ( $c$. EBGR 2003, 159; 2004, 251). The new finds include a small marble pillar, which

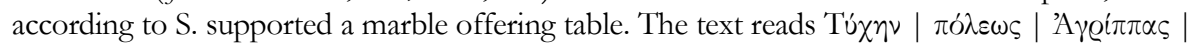

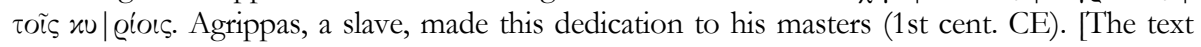
shows that the pillar supported a statue of Tyche. The reversed epsilon suggests a date in the late 1st cent. CE at the earliest. Given the discovery of this dedication in the Sebasteion, the 
xúgıı are either Flavia Mysta and her family, the founders of the Sebasteion (EBGR 2004, 251; SEG LIV 606), or the emperors (only if the text dates to the 2nd cent. CE).]

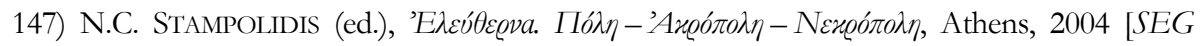
LIV 841, 843]: This catalogue of an exhibition on recent archaeological finds from Eleutherna on Crete includes numerous epigraphic finds. Among the inedita we single out a treaty between Eleutherna and Rhaukos (late 3rd cent.), presented by P. THEMELIS and A. MATTHAIOU (p. 156 $\mathrm{n}^{\circ}$ 12). The text contains a long list of the gods invoked by the two parties. The following names are preserved: Zeus Idatas, Zeus Thenatas, Hera, Poseidon, Ares, Aphrodite, Athena, Apollon Delphinios, Artemis, Welchanos, the Nymphs, and all the gods. T. KALPAXIS (p. 225 no 224) presents a gem of black stone (obsidian?); it is an amulet for the protection of the uterus. On the obverse it has the representation of a standing male figure with spear and shield, a hermaic stele or xoanon, a uterus, and a key, and on the reverse the magical word O@w@ıú $\theta$.

148) D. SumMA, “Attori e choregi in Attica: iscrizioni dal teatri di Thorikos", ZPE 157 (2006), p. 77-86 [BE 2007, 75; SEG LVI 46, 68, 199, 200, 231, 232]: S. re-examines a series of inscriptions (dedications, honorific decrees, regulations) that concern dramatic performances (only tragedy and comedy) in Thorikos (4th cent.) and the services provided by the choregoi (IG I3 1027 bis; Addenda 258 bis; SEG XXXIV 107, 174; XLV 167).

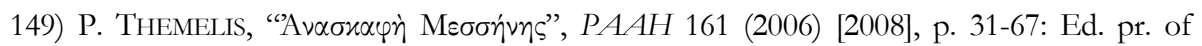
several inscriptions found during the excavation in Messene: 1) An honorary inscription for Kleonymos, an otherwise unattested boxer who won in the Olympic games in the 1st cent. (p. 36). 2) Two manumission records were inscribed on the rim of seats in the theatre (2nd cent., p. 37-40). In both cases the name of the agonothetes (of the Dionysia) Nikodamos is

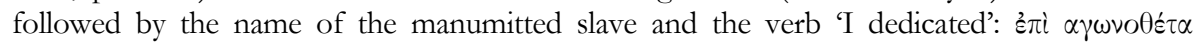

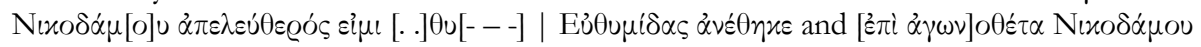

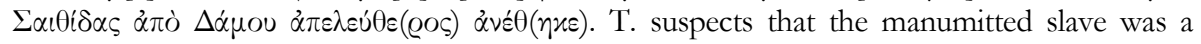
Dionysiac artist [This is very unlikely. The manumissions were recorded in the theatre because they were announced in the theatre prior to the theatrical performances. Manumission records have been found in theatres e.g. in Bouthrotos and Oiniadai (SEG LV 595)]. 3) A Latin dedication to the Emperor Marcus Aurelius (p. 46). 4) An honorary inscription mentioning an agonothetes (p. 47, 2nd cent. CE). 5) A dedication to Artemis found near the temple of Messene (p. 49, 3rd/2nd cent.). 6) A fragmentary inscription of 19 lines, which T. interprets as a

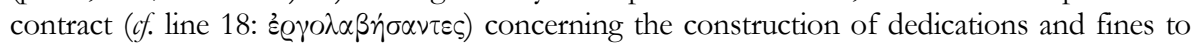
be paid in case of violation (p. 53f.). [This text is a decree concerning the acceptance of an endowment and regulating its administration; it refers to amounts of money and interest (line

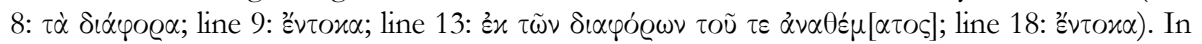

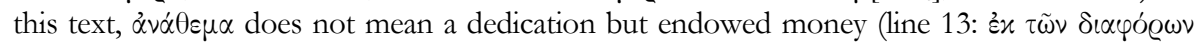

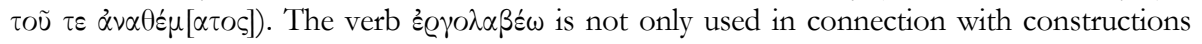

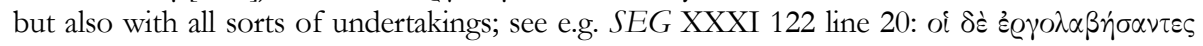
üixòv ì oivexóv.] 7) A small fragment on a bronze tablet (cult regulation?) mentions Artemis Limnatis (p. 58f.). 8) A list of ephebes is dated with reference to the priest of Zeus Ithomatas (p. 62-64). 9) A dedication to Zeus (p. 64, 2nd cent.). 10) A list of the sacred officials (kistiokosmoi and prostatai) of Kyparissia (p. 64, 4th cent.).

150) P. Thonemann, “A Ptolemaic Decree from Kourion”, ZPE 165 (2008), p. 87-95 [BE 2009, 534]: T. presents an improved edition of an inscription from Kition (originally published by I. MiCHELIDOU-NiCOLAOU, whose restorations are superseded by this edition). The Epilykoi and Parepilykoi, two groups of unknown character, honoured Andronikos, priest of the (Ptolemaic) kings, for his services (40 or $34 \mathrm{BCE}$ ). Among other things, he offered the appropriate sacrifices to Apollon Hylates, the city's patron, and to the other gods on behalf of 


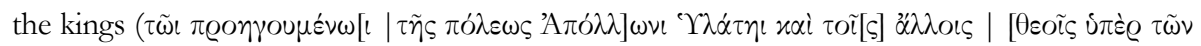

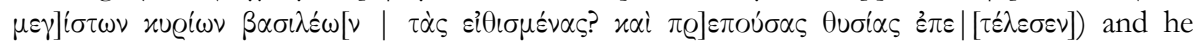

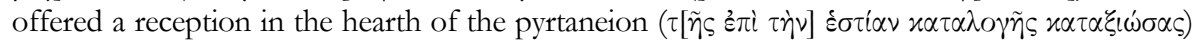

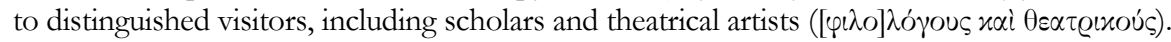

151) S.R. TokHTASYEV, "A New Curse Tablet from the North Shore of the Black Sea”, VDI 263 (2007.4), p. $48-49$ (in Russian) [BE 2008, 405]: Ed. pr. of a defixio written on a lead tablet and folded fourfold (Olbia?, 4th cent.). The text consists of four names in the nominative.

152) R.S.O. TomLIn, “Two Roman Lead Tablets from Leicester”, ZPE 167 (2008), p. 207218: Ed. pr. of two lead tablets with curses against thieves, found in a house at Leicester (Ratae Corieltauvorum, c. 150-250 CE). 1) 'I give to the god Maglus him who did wrong from the slave quarters: I give him who (did) theft of < the cloak $>$ from the slave-quarters; who stole the cloak of Servandus [the names of 19 suspects follow] ... I give that the god Maglus before the ninth day take away him who stole the cloak of Servandus'. [We note that the defigens reveals his name.] 2) 'Those who have stolen the silver coins of Sabinianus, that is Similis, Cupitus, Lochita, a god will strike down in this septisonium (i.e. a monumental façade with statues of the seven planetary deities), and I ask that they lose their life before seven days.' The tablet may have been written to be thrown into the water, in front of the septisonium. The deadline of seven days is probably connected with the seven statues; $c f$. Audollent, DefixTab 250 (seven days). The usual deadline in Britain is nine days (p. 215 n. 35).

153) R.S.O. TomlIN, "Special Delivery: A Graeco-Roman Gold Amulet for Healthy Childbirth", ZPE 167 (2008), p. 219-224 [BE 2009, 62 bis]: Ed. pr. of a gold amulet found south of Oxford (c. 250-350 CE); it is one of six such objects known in Britain. After a

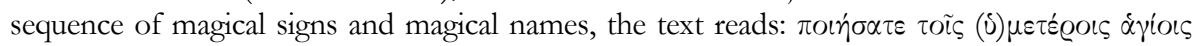

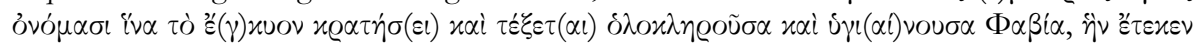

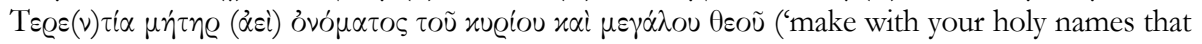
Fabia whom Terentia her mother bore, being in full fitness and health, shall master the unborn child and bring it to birth; the name of the Lord and Great God being everlasting'). T. rightly observes that there is no reason to assume that the text is Christian [cf. the suggestions of M. SÈVE, BE 2009, 62 bis, on some readings].

154) S.S. Torjussen, “An Inscribed Gold Olive Leaf from Daphniotissa Near Elis”, ZPE 166 (2008), p. 151-152 [BE 2009, 235]: T. discusses a gold leaf inscribed with the name of a woman, Palatha (Elis, 4th/3rd cent.; SEG XXXVIII 363). T. associates this leaf with a group of Dionysiac mystai. Similar leaves have been found in this part of the Peloponnese (Aigion and Elis).

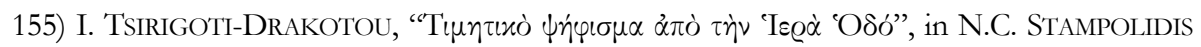

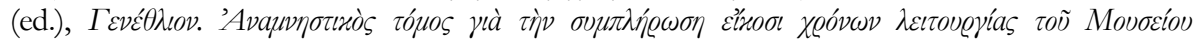

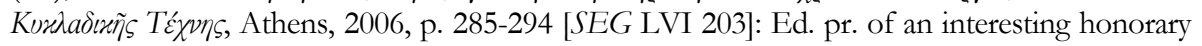
decree of the cult association (thiasos) of Agathe Thea for a woman from Kallatis, who served in a generous manner in the annual office of the supervisor ( $2 \pi \mu \varepsilon \lambda \dot{\eta} \tau \varrho \iota \alpha)$ of the association (Athens, 3rd cent.). She was appointed to this office by the assembly and by the priest and

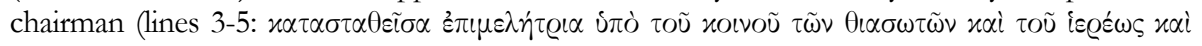

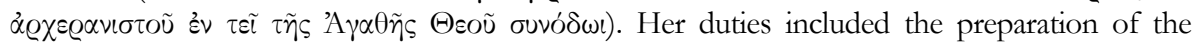
goddess' throne and of a table of offerings and the setting up of a torch in all meetings of the

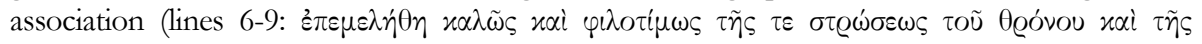

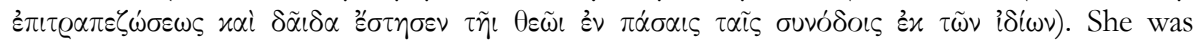
honoured with a wreath. This honour was to be announced every year by the hieropoioi on the occasion of the announcement of the sacrifice and the announcement of the crowning of the 


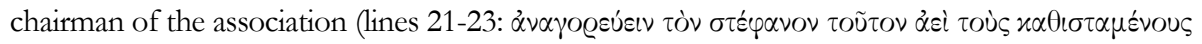

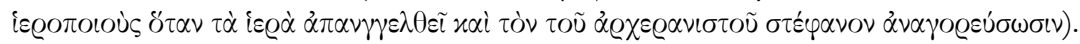

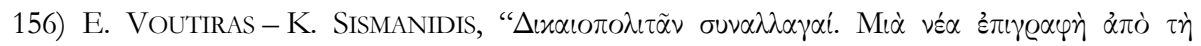

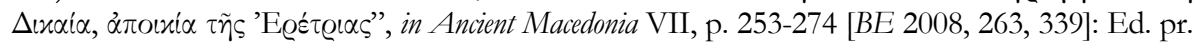
of a very important inscription from Dikaia in the Chalkidike (c. 364), consisting of a dossier of seven documents: five decrees concerning the procedure agreed upon for the reconciliation of two parties at Dikaia after a civil war, for trials of past homicide cases, and for amnesty; an amendment excluding two citizens from amnesty, possibly because of their involvement in killings; and an oath to be sworn by all citizens [the Greek text presented below is based on the improved edition by E. VOUTIRAS (see infra no 157]. All the decrees seem to have been passed in a single meeting of the assembly. Perdikkas III of Macedonia (365-359) served as witness and guarantor of the reconciliation. The oath and the agreements were to be published in the sanctuary of Athena and in the agora. The documents provide information for the calendar of Dikaia, which was influenced by the calendar of Eretria. With the exception of the trials concerning the sons of Hieron, the trials were to take place on the same day (25th Daphnephorion) during the year of the current archon (Gorgythos); the trials and oaths concerning the sons of Hieron were to take place later, in Lenaion and Anthesterion. Since in Ionian calendars Lenaion and Anthesterion correspond to January/February and February/March, and since the trials in Daphnephorion preceded those for the sons of Hieron, and, finally, since the New Year started in Euboia at the winter solstice, then Daphnephorion must be the first month of the year (December/January). [This reconstruction of the calendar is rejected by D. KNOEPFLER, BE 2008, 263.] Apart from the evidence concerning the calendar, the provisions concerning the oath are of great interest. The oath was to take place in the three most sacred sanctuaries and in the agora [see infra $\mathrm{n}^{\circ}$ 157] following the sacrifice of a boar; Zeus, Ge, Helios, and Poseidon were to be invoked; the arbitrators were to administer the oath (lines 5-8: " हैo $\delta \varepsilon$

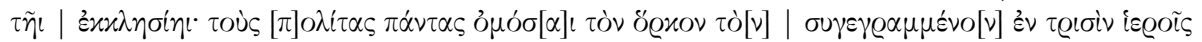

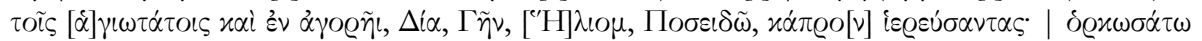

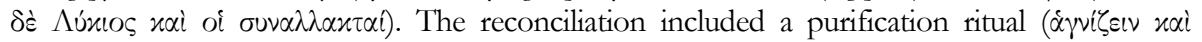
$\dot{\alpha} \gamma v i \zeta \varepsilon \sigma \theta \alpha i)$. Citizens who were absent should take the oath within three days after their return

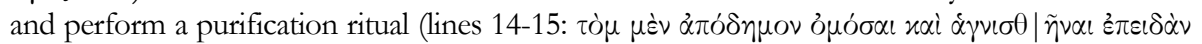
$\varepsilon^{\prime} \lambda \theta \eta \eta \tau(\tau i \tilde{\omega} \nu \hat{\eta} \mu \varepsilon \varrho \omega \tilde{\nu})$; sick individuals were to be sworn in within three days after recovery. Those who refused to take the oath were to be punished with loss of citizenship and confiscation of their property, which would become sacred property of Apollon Daphnephorios; the same penalty was imposed for violations of the amnesty. The text of the oath is quoted at the end of the inscription. It obliges the citizens to respect justice, to leave the constitution unchanged, not to invite foreigners (or mercenaries) to harm the city, and to respect the amnesty. Those who would violate the amnesty were to be dragged from the altars (lines 73-75: $\alpha^{\prime} \nu \tau \iota \varsigma \mu \nu \eta \sigma \varkappa \alpha x \tilde{\eta}$, oủx

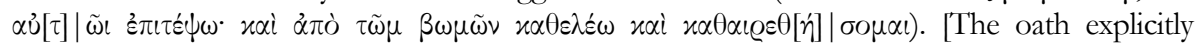
excludes from the right of supplication (taking refuge at an altar) those who violated the amnesty agreement; this confirms the assumption that there were legal mechanisms for the limitation of asylia in Greece, as I argued in an earlier article (EBGR 1996, 38 bis; cf. EBGR

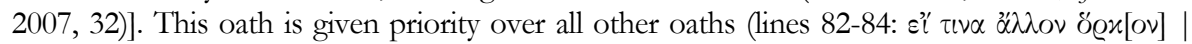

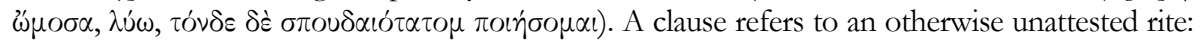
'I receive a token from the altar from Apollon in accordance with the oath that I swore (lines

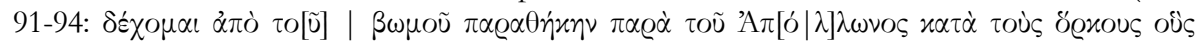
$\omega \mu \mid \sigma \sigma \alpha)$; this token was a portion of the victim or another item placed on the altar. Apollon and all the other gods would punish those who would commit perjury after having received this

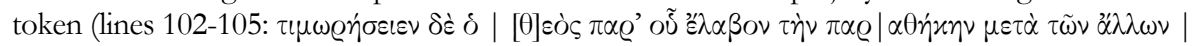
$\theta \varepsilon \tilde{\omega} \nu \pi \dot{\alpha} \nu \tau \omega \nu)$. 
157) E. VoutiRAs, "La réconciliation des Dikaiopolites : une nouvelle inscription de Dikaia de Thrace, colonie d'Érétrie", CRAI (2008), p. 781-792: V. presents an improved edition of the new inscription from Dikaia (supra no 156) and a French translation, and summarizes its content. He identifies the three sanctuaries in which the oath was to take place as those of Apollon Daphnephorios, Athena, and Artemis Amarysia.

158) A. Williams, "The Law Concerning the Little Panathenaia and the Leasing of the Né $\alpha$

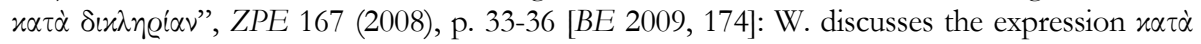
$\delta\left(x \lambda \eta{ }^{\prime} \alpha \alpha\right.$, which is used in connection with the manner in which the area called Nea was to be leased by the Athenians in order to provide the funds for the celebration of the Lesser Panathenaia (Agora XIX L7 = P.J. RHODES - R. OsBORNE, Greek Historical Inscriptions, Oxford, 2003 , no 81 ). This term probably refers to the division of the land into double-kleros lots, perhaps ten, which were leased for ten years and garnered rent of c. 400 drachmas each.

159) V.P. YAYLENKO, "Dedicatory Graffiti from Pantikapaion and Its Area", Drevnosti Bospora 9 (2006), p. 355-428 [BE 2009, 385; SEG LVI 911-912]: Y. presents 46 graffiti on vases (6th-3rd cent.) from the area of Pantikapaion. Y. identifies as dedicatory only the graffiti around the edge of these vessels. Only in some cases, the name of the deity is sufficiently preserved: Aphrodite (14), Apollon (1-3), (Apollon) Ietros/Iatros (6-7), Apollon Delphinios (8?), Artemis (10-11), Demeter (15-17), Dionysos (19-20), Herakles (36?, 37-38), Herakles Kallinikos (35), Hermes (21?, 22-25), Megale Thea (18), Zeus (40?, 42), Zeus Patroios (27-28), Zeus Soter (29, 31), Zeus Philetairos (32), Zeus Philios (33), Zeus Soter and Hermes Agathos (30). One of the graffiti commemorates a victory at the Apollonia (5). Y. also presents a new dedication to Apollon Delphinios (9) and republishes a dedication to Artemis Ephesie (13 = SEG XXXVI 721).

160) L. ZамвітO, “Un'epigrafe da Modica. Superstizione e religiosità nelle campagne in età tardoantica”, MEP 11 (2006), p. 366-376 [SEG LVI 1097]: Z. republishes a Christian exorcistic prayer for a vineyard with olive-trees from Modica (5th cent. CE; SEG XLIV 781; see EBGR $2000,19)$, with a few new readings and discussions of the angel's names [cf. supra $\mathrm{n}^{\circ} 107$ for such magical texts that aimed at promoting fertility].

161) N.V. ZAVOYKINA, “AIDHS v bosporskikh epitafijakh”, in Bosporskë fenomen 2, p. 309-313 (in Russian): Z. offers some observations on mentions of "Aı $\eta\rceil$ in Bosporan epitaphs. With the exception of the later Pantikapaian dipinto (CIRB 731), they are confined to a group of roughly contemporary epitaphs from Pantikapaion and Gorgippia (CIRB 119, 124-127, $129 / 130,132,139,141,146,1192$, c. 50 BCE-50 CE); the reasons for this phenomenon are not known.

162) E. ZwIERLEIN-DieHL, Siegel und Abdruck. Antike Gemmen in Bonn, Bonn, 2002 [SEG LVI 2055]: This catalogue of an exposition at the University of Bonn includes many inscribed gems (2nd-4th cent.) with magical words (113-122). The inscriptions include well-attested voces

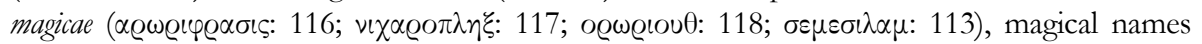
(I $\alpha \omega$ : 116), sequences of vowels $(113,115,120)$, the palindromic text $\alpha \beta \lambda \alpha \nu \alpha \theta \alpha \nu \alpha \lambda \beta \alpha$ (115),

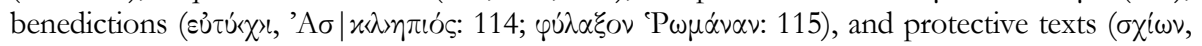
against lumbago: 118; uterine amulet: 120; $\pi \dot{\pi} \pi \tau$, for digestion: 119).

Angelos CHANIOTIS

School of Historical Studies

Institute for Advanced Study

Einstein Drive

Princeton, NJ 08540

E-mail:achaniotis@ias.edu 